\title{
Antarctic bacteria, sea ice ecosystem dynamics, and global climate change
}

\author{
A thesis \\ submitted in part fulfilment \\ of the requirements \\ for the degree \\ of \\ Master of Science in Ecology and Biodiversity \\ At \\ Victoria University of Wellington \\ By
}

\section{Andrew Robert Martin}

School of Biological Sciences

Victoria University of Wellington

New Zealand

2005 


\section{Abstract}

Productivity in the Southern Ocean reflects both the spatial and temporal dynamics of the sea ice ecosystem, as well as the complex cycling of energy through the microbial community. Marine bacteria are thought to be integral to trophodynamics and the functioning of a microbial loop within the ice matrix, but there is no clear understanding of the distribution and diversity of bacteria or the importance of bacterial production. Understanding the bacterial response to environmental change in the sea ice ecosystem may provide an insight into the potential changes to the physical oceanography and ecology of the Southern Ocean.

In this study, a multivariate statistical approach was used to compare the distribution and abundance of bacteria occurring in pack ice at the tongue of the Mertz Glacier (George V Coast, Antarctica) with bacteria from fast ice at Cape Hallett (Victoria Land coastline, Antarctica). Estimates of bacterial abundance were derived using both epifluorescence microscopy and flow cytometry and correlated with algal and chlorophyll $a$ data. Significant differences in the vertical distribution of cells within the ice were observed between the Mertz Glacier and Cape Hallett, but no overall difference in cell abundance was found between the two locations with $7.6 \pm 1.2 \times 10^{9}$ cells per $\mathrm{m}^{2}$ and $8.7 \pm 1.6 \times 10^{9}$ cells per $\mathrm{m}^{2}$ respectively. Bacteria and algae were positively correlated in pack ice of the Mertz Glacier indicating a functional microbial loop, but no discernable relationship was exhibited in multiyear ice at Cape Hallett. These findings support the general consensus that the generation of bacterial biomass from algal-derived dissolved organic matter is highly variable across seasons and habitats. 
The tetrazolium salt 5-cyano-2,3-ditolyl tetrazolium chloride (CTC) was used to investigate the bacterial response to experimentally induced changes in light and salinity in fast ice at Cape Hallett. Two distinct assemblages were examined; the brine channel assemblage near the surface of the ice and the interstitial or bottom assemblage. This study presents preliminary evidence that the metabolic activity of brine bacteria is influenced by light stimulus, most likely as a response to increased levels of algal-derived dissolved organic matter. No cells were deemed to be metabolically active when incubated in the dark, while on average thirty-eight percent of the cells incubated at $150 \mu \mathrm{mol}$ photons $\mathrm{m}^{-2} \mathrm{~s}^{-1}$ were metabolically active. Additional results indicate that salt concentration is more significant than light irradiance in influencing the metabolic response of cells present in the interstitial region of the sea ice profile. When acclimated over a period of eight hours, cells exhibited a tolerance to changing saline concentrations, but after a further eight hours there is some evidence to suggest activity is reduced at either end of the saline regime. Bacterial metabolic activity in each assemblage is thus thought to reflect the fundamentally different light and saline environments within the sea ice. Metabolic probes such as CTC will prove useful in providing a mechanistic understanding of productivity and trophodynamics in the Antarctic coastal ecosystem, and may contribute to prognostic models for qualifying the resilience of the microbial community to climate change. 


\section{Acknowledgements}

Many people have given generously of their time and knowledge in assisting me complete this thesis. First and foremost I would like to thank my supervisor, Dr. Ken Ryan for his patience, guidance and encouragement over the past two years. The opportunity to join the K043 team at Cape Hallett in 2003 and conduct research in Antarctica was truly inspirational - thank you!!

For assistance in delving into the 'black box' world of flow cytometry I gratefully acknowledge the expertise of Dr. Julie Hall (NIWA), Dr. Barry Sherr (Oregon State University), Dr. Anne La Flamme (Victoria University), Karen McCluskie (NIWA), Graeme Chapman (Becton Dickinson) and Joanna Roberts (Malaghan Institute).

For technical assistance at Cape Hallett I would like to thank Glenn Fenton (IRL) and for academic guidance Associate Professor Peter Ralph (UTS). Thanks to Shul Gordon as manager of the LGP project and Rachel Brown (camp manager) and Gus McAllister (camp mechanic). Thank you to Antarctica New Zealand for the logistic support offered to K043 in 2003.

For statistical assistance, the help of Dr. Shirley Pledger has been invaluable.

Special thanks go to doctoral students Thomas Gaitanos and Kevin Crume for general guidance and problem solving.

Dr. Ronan O'Toole and doctoral student Kelly Hare provided constructive feedback on early drafts of a number of chapters. 
The technical and administrative support at Victoria University has been fantastic, many thanks to: Alan Hoverd, Mary Murray, Delwyn Carter-Jarratt Lesley Milicich, Peter Watson, Chris Thorn, Sushila Pillai, Sam Court, Kaye Ballantyne, Jo Long, and Cameron Jack.

Thanks to my family for supporting me and taking an interest in my work and all those, past and present, in KK702.

Lastly, thanks to all those who offered to assist in the field - this is pretty much every one I know!! 
Abstract $\quad$ ii

Acknowledgements $\quad$ iv

$\begin{array}{ll}\text { CHAPTER 1: General introduction } & 1\end{array}$

1.1 Antarctica and Climate Change 3

1.2 Sea ice characteristics and the Marginal Ice Zone 5

$\begin{array}{lll}1.3 & \text { Sea ice microbial assemblages - Distribution and composition } & 10\end{array}$

1.4 Cape Hallett and the Latitudinal Gradient Project 14

$\begin{array}{lll}1.5 & \text { Research aims } & 17\end{array}$

CHAPTER 2: Site descriptions, introduction to techniques for enumerating 19 bacterial cells, and development of methods

2.1 Cape Hallett site description $\quad 19$

$\begin{array}{lll}2.2 & \text { Mertz Glacier site description } & 20\end{array}$

2.3 Epifluorescence microscopy 22

$\begin{array}{lll}2.4 & \text { Flow cytometry } & 25\end{array}$

$\begin{array}{lll}2.4 .1 & \text { Fluidics system } & 25\end{array}$

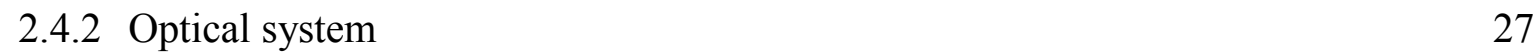

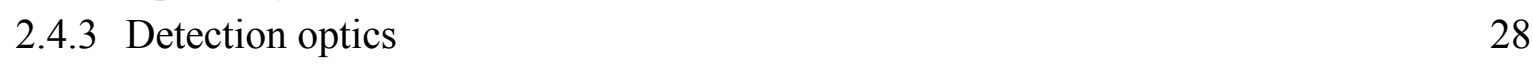

2.4.4 Electronics system 30

$\begin{array}{lll}2.5 & \text { Filtration } & 31\end{array}$

2.6 Filtration membranes $\quad 32$

2.7 Antifade 33

2.8 Treatment of ethanol preserved samples $\quad 34$

$\begin{array}{lll}2.9 & \text { Bacterial cell stains } & 35\end{array}$

2.9.1 DAPI 35

$\begin{array}{ll}2.9 .2 \text { CTC } & 35\end{array}$

2.9 .3 CFDA 36

2.10 Flow cytometry calibration $\quad 36$

2.11 Wellington Harbour pilot study 38

CHAPTER 3: Distribution and abundance of sea ice bacteria from two locations in coastal Antarctica and evidence for the microbial loop 42

3.1 Introduction $\quad 42$

$\begin{array}{lll}3.2 & \text { Methods } & 48\end{array}$ 
3.2.1 Sample collection $\quad 48$

3.2.2 Epifluorescence microscopy 49

3.2.3 Flow cytometry 51

3.2.4 Image analysis $\quad 52$

3.2.5 Calculation of biovolume $\quad 53$

3.2.6 Statistical analysis $\quad 54$

3.3 Results $\quad 56$

3.3.1 Image analysis $\quad 56$

3.3.2 Bacterial enumeration: comparison of flow cytometry and epifluorescence microscopy $\quad 57$

3.3.3 Abundance and distribution $\quad 57$

3.3.4 Distribution of bacterial cells within the ice profile $\quad 62$

$\begin{array}{ll}\text { 3.3.5 Correlation among response variables } & 66\end{array}$

$\begin{array}{lll}3.4 & \text { Discussion } & 67\end{array}$

$\begin{array}{lll}\text { 3.4.1 Enumeration of bacterial cells } & 68\end{array}$

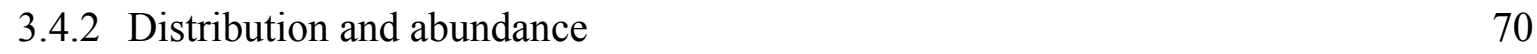

$\begin{array}{ll}3.4 .3 & \text { Evidence for the microbial loop }\end{array}$

CHAPTER 4: Metabolic assessment of Antarctic sea ice bacteria $\quad 78$

$\begin{array}{lll}4.1 & \text { Introduction } & 79\end{array}$

$\begin{array}{lll}4.2 & \text { Methods } & 83\end{array}$

4.2.1 Sample collection $\quad 83$

$\begin{array}{ll}\text { 4.2.2 Experimental protocol } & 85\end{array}$

$\begin{array}{lll}4.2 .3 & \text { Statistical analyses } & 88\end{array}$

$\begin{array}{lll}4.3 & \text { Results } & 89\end{array}$

4.3.1 Effect of light on the brine community $\quad 89$

4.3.2 Effect of light and salinity on the bottom community 91

4.4 Discussion 96

4.4.1 Response of brine community to light $\quad 97$

4.4.2 Response of bottom community to light and salinity 99

$\begin{array}{ll}\text { CHAPTER 5: Summary } & 103\end{array}$

5.1 Development of methods $\quad 104$

5.2 Distribution and abundance 105

$\begin{array}{ll}5.3 \text { Cell metabolic activity } & 105\end{array}$

$\begin{array}{lll}5.4 \text { Conclusion } & 107\end{array}$

$\begin{array}{ll}5.5 & \text { Limitations of the study } \\ 5.6 & \text { Future directions }\end{array}$

$\begin{array}{lll}5.6 & \text { Future directions } & 110\end{array}$

$\begin{array}{ll}\text { REFERENCES } & 113\end{array}$ 


\section{Chapter 1: General introduction}

Antarctica is a focal point for two of the most significant global environmental pressures: stratospheric ozone depletion and global warming (Waterhouse, 2001).

While the causal mechanisms and implications for climate change remain controversial, it has become widely recognised that human generated emissions have altered the global climate system (Manning and Nobre, 2001). The global average surface temperature has increased by $0.6 \pm 0.2^{\circ} \mathrm{C}$ since the late $19^{\text {th }}$ century and is projected to increase by 1.4 to $5.8^{\circ} \mathrm{C}$ by 2100 (Joos et al., 2001). This increase in global temperature is due in part to dramatic changes in the concentration of naturally occurring greenhouses gases such as carbon dioxide, ozone, methane, and nitrous oxide that absorb long-wave (infrared) radiation in the atmosphere. Increases in the concentration of gases which re-emit the radiation absorbed from the Earth's surface: carbon dioxide, methane, and nitrous oxide, have reduced the efficiency with which the Earth's surface radiates to space, thus warming the lower atmosphere and the surface of the planet (Waterhouse, 2001).

The most important anthropogenic emission leading to an increase in global temperature both today, and in the foreseeable future, is carbon dioxide $\left(\mathrm{CO}_{2}\right)$ (Sariento and Le Quere, 1996). While the concentration of carbon dioxide in the atmosphere and oceans fluctuates naturally in a vast cycle involving transfer between the land surface, oceans, atmosphere and lithosphere (Bigg et al., 2003), the current atmospheric concentration of carbon dioxide has not been exceeded during the past 420,000 years and likely not during 
the past 20 million years. The burning of fossil fuel accounts for much of the observed increase in $\mathrm{CO}_{2}$ levels, and the rest $(10-30 \%)$ is due predominantly to land-use change, especially deforestation (Joos et al., 2001).

Covering approximately $10 \%$ of the world's oceans, the Southern Ocean is a significant component of the global marine ecosystem (Constable and Nicol, 2003) and, along with the North Atlantic, is a major oceanographic sink for $\mathrm{CO}_{2}$. The exchange of $\mathrm{CO}_{2}$ between the atmosphere and oceans has both a physical and biological component. The physical exchange of $\mathrm{CO}_{2}$ is governed by seawater temperature; $\mathrm{CO}_{2}$ is more soluble in seawater at lower temperatures and ocean circulation carries this cold $\mathrm{CO}_{2}$-enriched water into the deep ocean (Bigg et al., 2003). In addition to the physical atmosphere/ocean exchange, $\mathrm{CO}_{2}$ is utilised by phytoplankton in the surface of the oceans and converted into plant biomass. Although most of the $\mathrm{CO}_{2}$ returns to the water and atmosphere through respiration and through decomposition when these primary producers are eaten or die, a proportion is lost to the deep sea and sediments as sinking particles where it can remain for substantial periods of time (Nybakken, 1997).

The Southern Ocean is thus an active component of the climate system regulating the flux of $\mathrm{CO}_{2}$ between the atmosphere and ocean. $\mathrm{As}^{\mathrm{CO}_{2}}$ emissions increase however, both the physical and biological drawdown mechanisms may become self-limited in their ability to sequester anthropogenic $\mathrm{C}_{2}$. Any increase in sea surface temperature will limit the physical exchange as Arrigo et al (1999) have recently shown in the Ross Sea. The capacity of phytoplankton to remove $\mathrm{CO}_{2}$ is determined by community structure within 
the water column, which is in turn influenced by surface ocean stratification and ultimately precipitation in the Southern Ocean. As a result, microbial community structure and productivity can vary depending on the physico-chemical characteristics of the water column in different areas of the Southern Ocean (Vaqué et al., 2002). If climate change is sustained there are likely to be long-term changes in the physical oceanography and ecology of the Southern Ocean (Manning and Nobre, 2001).

\subsection{Antarctica and Climate Change}

While climate change will affect key polar drivers, such as sea-level rise and greenhouse gas emissions, few data are currently available to quantatively assess both the direct and indirect impacts of climate change on the Antarctic biota (Manning and Nobre, 2001). Of all the responses to future global climatic warming from increasing concentrations of atmospheric trace gases however, changes to the distribution of Antarctic sea ice can be expected to be among the most notable (Budd, 1991). Regional warming has already instigated both the retreat and collapse of ice shelves around the Antarctic Peninsula with implications for terrestrial ecosystems, such as the colonisation of exotic plants and animals on the peninsula (Manning and Nobre, 2001). Reid and Croxall (2001) suggest that reduced sea ice cover has instigated changes in the population structure of Antarctic krill (Euphausia superba) and the subsequent reduction in krill biomass may now be insufficient to support predator demand in some years. While satellite observations over the period 1973-1996 show no significant change in Antarctic sea ice extent, whaling records and modelling analyses indicate a southward retreat by 2.8 degrees of latitude 
between the mid 1950's and early 1970's (Manning and Nobre, 2001). Substantial warming and changes in precipitation are projected for polar regions over the $21^{\text {st }}$ century by almost all climate models. Current models project that by 2100 atmospheric carbon concentrations will be in the order of 540 to $970 \mathrm{ppm}$ (90 to $250 \%$ above the concentration of $280 \mathrm{ppm}$ in 1750) (Joos et al., 2001). Gordon and O'Farrell (1997) suggest that a doubling of current carbon dioxide levels will lead to a reduction in the volume of Antarctic sea ice of about $25-45 \%$. This CSIRO climate model assumes a $1 \%$ per year compounding increase of $\mathrm{CO}_{2}$, corresponding to a warming of the globe by $2.1^{\circ} \mathrm{C}$. Wu et al. (1997) used a model with higher albedo feedback (warming of $2.8^{\circ} \mathrm{C}$ ) and predict a reduction in mean sea ice extent of nearly two degrees of latitude, which corresponds to $45 \%$ of the current sea ice volume. It is likely that sea ice will provide a sensitive indicator of climatic change in coming decades, declining in response to warmer atmospheric and oceanic temperatures (Wolff, 2003).

While the effect of climate change on sea ice dynamics and primary production within the Antarctic coastal ecosystem is not well understood there are thought to be significant ecological consequences to changes in the magnitude and timing of seasonal sea ice advance and retreat (Smith et al., 1998; Thomas and Dieckmann, 2002). Surface waters of the Southern Ocean have already warmed and become less saline suggesting that future changes to the extent and volume of sea ice may have profound impacts on the physical oceanography and ecology of the Southern Ocean. Such changes are likely to have profound impacts at all levels of the food chain, from algae to krill to the great whales (Manning and Nobre, 2001). 


\subsection{Sea ice characteristics and the Marginal Ice Zone}

Although a transient phenomenon, sea ice is a predominant feature of polar oceans and exerts a unique influence on Antarctic marine ecosystems. Sea ice expands and contracts annually in a concentric zone around the Antarctic continent; during the winter as much as 20 million $\mathrm{km}^{2}$ of sea ice forms in the Southern Ocean, of which all but 4 million $\mathrm{km}^{2}$ melts during the austral summer. This ice regime strongly affects the physical and biological processes associated with marine ecosystems, particularly in modulating the exchange of heat and moisture between the atmosphere and ocean and restricting the penetration of solar radiation (Delille, 1992; Manning and Nobre, 2001).

Productivity in the Southern Ocean is thus characterised by large-scale spatial and temporal variability as the sea ice influences not only the pelagic systems under the ice but also determines the ecology of the biota within the ice (Legendre et al., 1992; Ackley and Sullivan, 1994). Interest in the degree of productivity has arisen due to the status of the Southern Ocean in influencing global carbon fluxes, its capacity to support large populations of vertebrates, and the ecological consequences of harvesting marine resources (Constable and Nicol, 2003).

Early productivity estimates from the Southern Ocean were puzzlingly low however, given the accounts from early explorers and whaling expeditions of prolific krill, seal, whale and bird numbers (Garrison et al., 1986). This inconsistency between predicted and observed production rates has only recently been explained and the 'missing production' 
attributed to what is thought to be the most dynamic microbial habitat in the Southern Ocean; the marginal ice zone (Vincent, 1988).

When the sea ice melts each year, conditions at the edge of the receding pack ice include strong vertical gradients in temperature and salinity and also upwelling of nutrients, all of which support periods of intense microbial productivity. The development of phytoplankton and bacterial blooms stimulates the activity of other microbial groups and trophic levels (Vincent, 1988), a process that essentially forms the energy base for the Southern Ocean. Bacteria are thought to support a significant biomass of microheterotrophs that are involved in a microbial loop associated with the ice and may in turn support higher trophic levels (Garrison et al., 1986; Kottmeier et al., 1987), while sea ice algae are the primary source for krill which are consumed by squid, penguins, seals and baleen whales (Thomas and Dieckmann, 2002).

The projected reductions in the extent of annual sea ice may limit the development and physical characteristics of sea ice at the marginal zone. Such changes are likely to influence the dynamics and interactions of the whole marine ecosystem. It is not currently known whether a reduction in ice cover would lead to an increase or decrease in productivity within the water column and/or the sea floor, or how the timing and magnitude of bloom events would be altered.

As sea ice forms, dissolved salts are excluded from the freshwater matrix and become concentrated in microscopic brine pockets or inclusions (Garrison, 1991). Along with the 
influence of gravity and seasonal melting, this process results in a network of brine channels as secondary structural features occupying between $1-30 \%$ of the ice volume. The differential between the polar atmosphere and warmer underlying water causes a vertical temperature and salinity gradient within the ice (Garrison, 1991; Staley et al., 2002; Arrigo and Sullivan, 1992), which strongly influences the distribution of microbial species.

Sea ice can be defined according to several basic structural types: frazil ice, platelet ice, congelation ice and snow ice. Initial formation occurs at or near the surface of the water with small platelets and crystalline needles termed frazil ice (Knox, 1994). Crystals typically develop in open water where turbulent mixing leads to the supercooling of nearshore waters (Palmisano and Garrison, 1993). These crystals accumulate at the seawater surface first as a slushy layer known as grease ice, and then coalesce to form nilas or sheet ice under calm conditions, or pancake ice if there is any wave action (Garrison, 1991). Frazil ice often contains a high concentration of biological material as particulates from the water column become concentrated during ice formation (Palmisano and Garrison, 1993). Congelation or columnar ice forms at the ice-water interface under preestablished ice cover. This ice type is composed of columnar crystals that are orientated vertically with respect to the ice and have defined brine inclusions between adjacent crystals. Late in the season, depression of ice flows may lead to the formation of snow ice as seawater floods the floes and forms a layer of infiltration ice along the snow-ice interface (Staley et al., 2002). In most regions of Antarctica ice-cover is an annual phenomenon that can be divided into a zone of fast ice that remains attached to the 
shoreline, and free-floating pack ice which extends into deep-water regions (Garrison, 1991; Vincent, 1988).

The formation of sea ice is accompanied by large changes not only in temperature and salinity, but also light and carbon supply, which results in very different types of microenvironment for the development of microbial communities (Knox, 1994). A schematic representation of these habitats is shown in Figure 1.1. Three broad community categories have been recognised (Palmisano and Sullivan, 1983). The bottom ice community is comprised of microbes that inhabit the interstices of a platelet layer if it is present, and also those species that live at the base of the congelation ice in brine pockets and drainage channels. This community is made up of mat, chain, and column-forming algal species that anchor to the ice-water interface and hang down into the seawater below (Garrison, 1991). The second microbial community, found close to the ice profile surface, occupies a similarly diverse range of microenvironments including melt pools, snow infiltrated with seawater, and the snow-ice-seawater mixture that accumulates in tide cracks (Vincent, 1988; Garrison and Buck, 1991; Fritsen et al., 2001). A third community is made up of those species occurring at mid-depth within the ice profile as either band assemblages or brine channel assemblages (Knox, 1994; Garrison, 1991). 


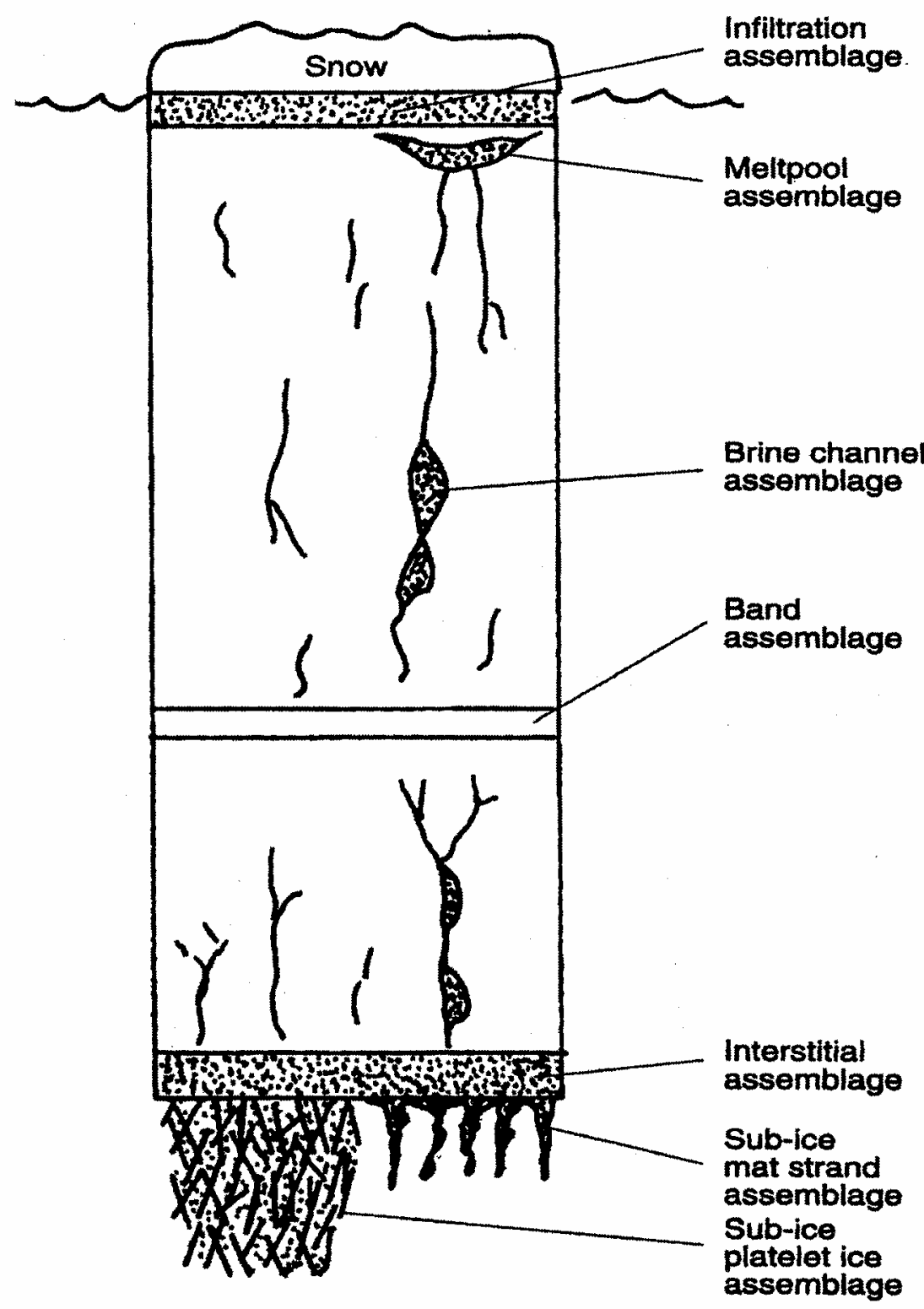

Figure 1.1 Schematic representation of the different microbial assemblages associated with sea ice (Knox 1994). 


\subsection{Sea ice microbial assemblages - Distribution and composition}

The sea ice supports a complex microbial biota often termed the 'sea ice microbial community' (SIMCO). The primary producers in this community are mostly pennate diatoms and efforts to investigate the biology of sea ice have focused on the composition, physiology, and ecology of the algae that dominate fast ice assemblages (e.g. Garrison, 1991; Arrigo et al., 1998; McMinn et al., 2000; Thomas et al., 2001; Ryan et al., 2002; Trenerry et al., 2002). In addition, protozoa, bacteria, fungi, and invertebrates are also present within the ice (Garrison et al., 1986; Vincent, 1988; Garrison, 1991; Staley and Gosink, 1999; Staley et al., 2002).

As recently as 1968 however, microbiologists had suggested that bacterial numbers were extremely low or even nonexistent in polar seas (Sorokin, 1971 cited in Sullivan, 1985). Although it is now known that diverse assemblages of bacteria are present in the polar environment, the literature on bacteria and their role in the sea ice community is somewhat limited. Much of the current knowledge comes from studies by Sullivan and Palmisano $(1981 ; 1984)$ and their co-workers (Grossi et al., 1984; Sullivan, 1985; Sullivan et al., 1984; Kottmeier, et al., 1987; Kottmeier and Sullivan, 1988) in the McMurdo Sound region. Little work has been done in the last ten years.

Early studies using scanning electron microscopy revealed a variety of morphologically distinct bacterial cell types including coccoid, rod, fusiform, filamentous, and prosthecate forms within the ice. Fast ice cores from McMurdo Sound showed that $47 \%$ of the 
bacterial numbers and $93 \%$ of the bacterial biomass was located in the bottom $20 \mathrm{~cm}$ of the ice column. Free-living bacteria comprised $70 \%$ of the total numbers, while the remaining 30\% were found either attached to living algal cells or detritus (Sullivan and Palmisano, 1984). In contrast to bacterioplankton within the water column, ice bacteria were found to be 5-10 fold larger, often occurring as paired or dividing cells. This suggested that cells might be active at sub-zero conditions within the ice. Microautoradiographic uptake of radiolabeled compounds such as ${ }^{14} \mathrm{C}$-L-serine, ${ }^{3} \mathrm{H}$ serine, ${ }^{3} \mathrm{H}$-glucose and ${ }^{3} \mathrm{H}$-thymidine by bacteria incubated under in situ conditions provided additional evidence of metabolic activity in the form of DNA synthesis (Sullivan and Palmisano, 1984; Sullivan et al., 1985).

This seminal research led Sullivan (1985) to suggest that bacteria may play an important role in the following processes:

1. Secondary microbial production mediated through the microbial loop.

2. Remineralisation and recycling of ice-associated organic matter.

3. Maintenance of a balance in the ice microenvironment with regard to detoxification and oxygen consumption.

4. Trace gas production.

5. Ice nucleation and early stages of sea ice formation.

An active microbial loop and the remineralisation of dissolved organic material imply bacteria are integral to the functioning of the sea ice ecosystem. Several authors have 
found a positive relationship between bacterial and algal biomass/production in sea ice during spring/summer (Grossi et al., 1984; Kottmeier et al., 1987; Kottmeier and Sullivan, 1990; Delille et al., 1995; Stewart and Fritsen, 2004). This relationship develops when bacteria assimilate dissolved organic matter (DOM) that is generated through processes such as the release of dissolved photosynthate by algae or the rupture and degradation of algal cells during grazing. In return, bacteria are thought to facilitate algalbased primary production occurring within sea ice by providing algae with the remineralised nutrients necessary for continued growth (Kottmeier et al., 1987; Kottmeier and Sullivan, 1990; Archer et al., 1996). The assimilation by bacteria of algal-derived DOM is a core process in the microbial loop hypothesis, but remains equivocal with respect to the spatial and temporal dynamics of the sea ice ecosystem (Ducklow et al., 1999; Stewart and Fritsen, 2004). For example, Kottmeier and Sullivan (1987) and Stewart and Fristen (2004) found no significant relationship between algae and bacteria in late winter sea ice west of the Antarctic Peninsula.

The links between bacterial secondary production and higher trophic levels is equally equivocal. The microscopic fraction of the sea ice community is known to be an important food source for crustaceous zooplankton such as the Antarctic krill Euphausia superba Dana (Daly, 1990; Kottmeier and Sullivan, 1990; Stewart and Fritsen, 2004), but little is known about the exact trophic relationships between these organisms or rates of carbon transfer (Cota et al., 1990). As much as 20-30\% of the ice-bound primary production may be cycled through to higher trophic levels via the consumption of bacteria by nanoplankton and microzooplankton such as flagellates and ciliates (Staley et 
al., 2002). However, this is a complex relationship between sea ice dynamics such as ice type, distribution of organic and inorganic nutrients and photosynthetically active radiation (PAR), and the structure of the sea ice biota which modifies energy cycling through the community (Vaqué et al., 2002; Stewart and Fritsen, 2004). As such, the quantitative importance of bacterial production is difficult to assess (Kottmeier and Sullivan, 1990), but it is likely that bacteria released from melting ice contribute to microbial blooms at the marginal ice zone and participate in a microbial loop within the ice matrix which may in turn support higher trophic levels (Kottmeier et al., 1987).

With recent developments in molecular procedures and culture-based analysis, a taxonomic assessment of the bacterial species is considered vital for the further understanding of sea ice microbial processes (Brown, 2000). Assessing microbial diversity however is considered to be a daunting task (Staley and Gosink, 1999). Recent efforts based on 16S rDNA sequences of pure cultures indicates that sea ice bacteria fall into five major phylogenetic groups: the Proteobacteria, the Cytophaga-FlavobacteriumBacteroides (CFB) group, the verrucomicrobia and the high and low mol percent grampositive bacteria (Staley and Gosink, 1999; Brown, 2000)(Figure 1.2).

Representatives from the Archaea have been described from the water column, including the Crenarchaeota and Euryarchaeota, which may also be present in the sea ice (Staley et al., 2002). Bacteria thus far isolated from the sea ice have been heterotrophic organisms utilising the organic substances produced by diatoms and other algae. It is not yet known whether any might be photosynthetic or chemosynthetic (Staley et al., 2002). 


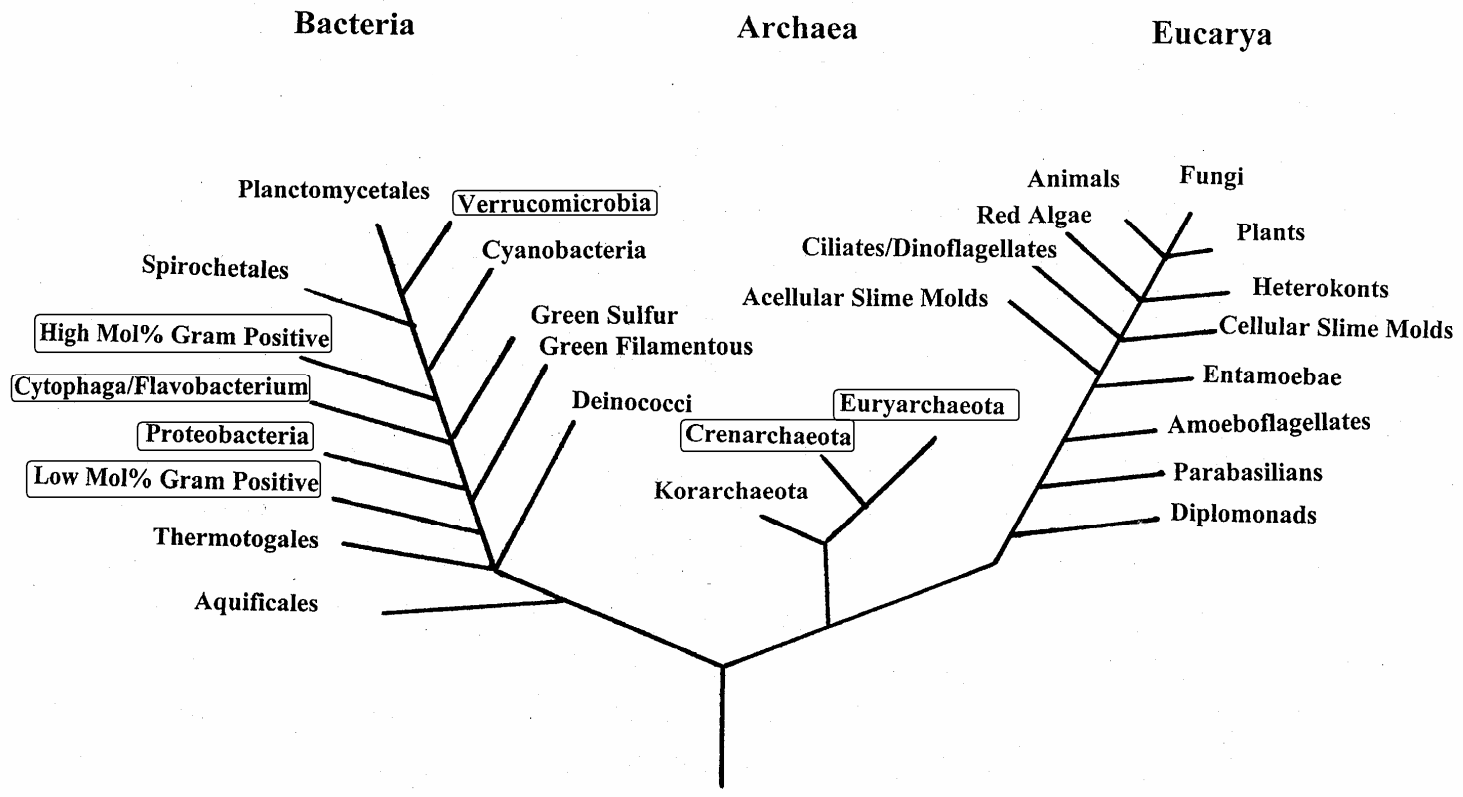

Figure 1.2. The Universal Tree of Life showing the major phyla of Bacteria, Archaea and Eucarya based on small subunit rRNA sequences (Staley, 2002).

\subsection{Cape Hallett and the Latitudinal Gradient Project}

The Victoria Land mountain chain and coastline within the Ross Sea region contains the most extensive coastal gradient in Antarctica: Cape Adare $\left(68^{\circ} \mathrm{S}\right)$ to the southern end of the Ross Ice Shelf $\left(86^{\circ} \mathrm{S}\right)$, and includes a variety of marine, terrestrial and freshwater habitats. Important environmental factors including solar radiation (annual radiation, UV radiation), temperature, day length and sea ice cover vary predictably along this gradient and are likely to exert a significant influence on ecological processes (Howard-Williams and Peterson, 1998). The Latitudinal Gradient Project (LGP) which commenced in the 
2003/2004 Antarctic field season aims to develop an understanding of the ecosystems that exist along the Victoria Land coastline and to describe the potential environmental variability that may occur in the future (Gordon, 2003). Although various other studies have attempted or are currently working to describe ecosystem/environmental variation, (e.g. the Long Term Ecological Research project (LTER) in the McMurdo Dry Valleys) a latitudinal coastal, marine and terrestrial survey of physical and biological parameters will be a unique initiative. The Latitudinal Gradient Project will visit five sites along the Victoria Land coast: Cape Hallett, Terra Nova Bay, Granite Harbour, Darwin Glacier and the Beardmore Glacier (Figure 1.3). The project is expected to span 15 years from 2003/2004 with the information gained from the different sites along the coast helping to predict future effects of environmental change in Antarctica (Gordon, 2003). 


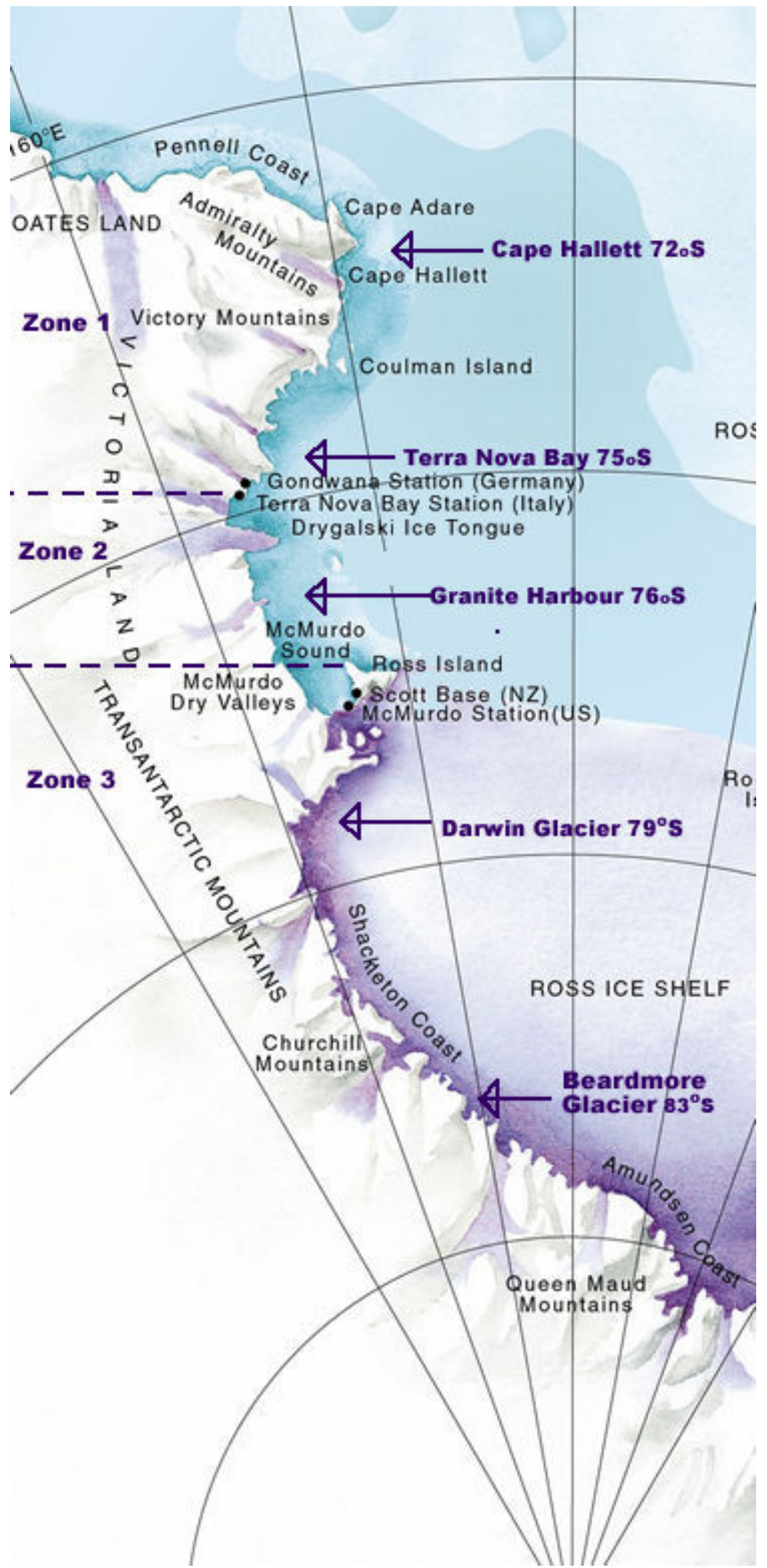

Figure 1.1 Map of the Ross Sea showing Latitudinal Gradient and LGP research sites (Gordon, 2003). 


\subsection{Research Aims}

Understanding the spatial and temporal dynamics of Antarctic sea ice and the associated biotic communities is fundamental to quantifying Southern Ocean productivity and the trophodynamics of the Antarctic coastal ecosystem. However, bacterial production has generally been overlooked in estimates of Southern Ocean productivity and the literature on bacteria associated with sea ice is somewhat limited. If current climate trends are sustained, changes in the volume and extent of sea ice, ocean circulation, mixing regimes, cloud cover and nutrient input will influence the microbial communities that characterise the sea ice environment. An appreciation of the response of bacterial assemblages to environmental change is likely to provide an insight into the potentially long-term changes to productivity in the sea ice ecosystem.

The aim of this thesis is to develop an understanding of the techniques utilised in the field of microbial ecology and to incorporate these techniques in examining the bacteria found within Antarctic sea ice. Chapter 2 provides a description of the field sites and provides an introduction to epifluorescence microscopy and flow cytometry. Included also is a summary of the development and calibration of the methods described in subsequent chapters and a short pilot study on bacteria in Wellington Harbour.

In Chapter 3 two methods for assessing bacterial cell abundance are compared: epifluorescence microscopy and flow cytometry. This chapter also compares the distribution and abundance of bacteria within annual sea ice at two locations in 
Antarctica; the Mertz Glacier (pack ice) and Cape Hallett (fast ice). In addition, the microbial loop hypothesis is evaluated by comparing bacterial data with algal counts and measurements of Chl $a$ from concurrent samples.

A novel application of the vital tetrazolium stain CTC to determine cell metabolic activity is the focus of Chapter 4 . This study assesses the bacterial response to changing light and salinity levels as a proxy for climate-induced change in the sea ice environment. Chapter 5 summarises the findings of the thesis, provides general conclusions and considers future research directions. Chapter 3 and Chapter 4 have been written as self-contained research papers for publication. As a consequence there is some repetition in the introductions and discussions. 


\section{Chapter 2: Site descriptions, introduction to techniques for enumerating bacterial cells, and development of methods}

This chapter describes the locations where bacterial samples were collected in 2002 and 2003 and also provides an introduction to epifluorescence microscopy and flow cytometry. The rationale behind the methods adopted in subsequent experiments are briefly described, along with a short pilot study on bacteria in Wellington Harbour.

\subsection{Cape Hallett site description}

Cape Hallett $\left(72^{\circ} 19^{\prime} \mathrm{S} 170^{\circ} 16^{\prime} \mathrm{E}\right)$ is located at the southern end of Moubray Bay, Northern Victoria Land, in the Western Ross Sea (Gordon, 2003)(Figure 2.1). The cape forms the northern point of the north-south aligned Hallett Peninsula that is 32 $\mathrm{km}$ long and approximately $8 \mathrm{~km}$ wide (Harrington et al., 1967). The peninsula joins the mainland by way of a narrow ridge between Tucker Glacier and Edisto Inlet. Seabee Hook is a recurved spit composed of coarse low-lying volcanic material that projects about $1200 \mathrm{~m}$ west from the high rocky ridge forming Cape Hallett.

The LGP campsite was situated on the edge of Willett Cove, a small bay enclosed on the south side of Seabee Hook (Gordon, 2003). All but a few protruding scoria ridges on Hallett Peninsula are covered by a mantle of undulating ice. This ice mostly drains into Edisto Inlet where glaciers drape the cliffs on the east side of the bay (Harrington et al., 1967). Satellite data collected from 1979 to 2000 suggests that sea ice remains at Cape Hallett after the rest of the coast from Cape Adare to Coulman Island is clear of ice. The average time until ice- free water eventually appears $\left(27^{\text {th }} \mathrm{Jan}\right)$ has a 
standard deviation of two weeks and while on average this ice-free period extends until $2^{\text {nd }}$ March, in some years the ice does not completely clear at all (Falconer and Pyne, 2000).

Seabee Hook is the site of an Adelie penguin colony with an estimated population of 40,000 breeding pairs. Although not permanent residents at Cape Hallett, other birds have been observed in the area besides the Adelie penguins including snow petrel, southern Giant Petrel, Wilson's storm petrel, Chinstrap penguin, Emperor penguin, and the Southern Black-backed gull. Observed marine fauna include Crabeater seal, Weddell seal, Elephant seal, Leopard seal, Minke whale and Fin whale (Gordon, 2003).

\subsection{Mertz Glacier site description}

The Mertz Glacier and its associated coastal polynya are located off eastern Antarctica in the vicinity of George V Land $\left(66^{\circ} \mathrm{S}, 147^{\circ} \mathrm{E}\right)$. The Mertz Glacier tongue projects seaward about $160 \mathrm{~km}$ from the Antarctic coast at approximately $145^{\circ} \mathrm{E}$, which causes ice build-up upwind of the glacier, while preventing ice advection into the region from the east to west/southwest where polynyas of dual origin coalesce to form the Mertz Glacier Polynya (Massom et al., 2003). Coastal polynyas are typically regions of enhanced oceanic primary and secondary production and the growth and accumulation of phytoplankton in particular is greater within polynyas than in adjacent waters (Arrigo and van Dijken, 2003). Dr. Ken Ryan collected the pack ice samples used in this thesis in 2002 during a voyage on the Australian research vessel Aurora Australis in conjunction with Dr. Andrew McMinn and the Australian Antarctic Division. 


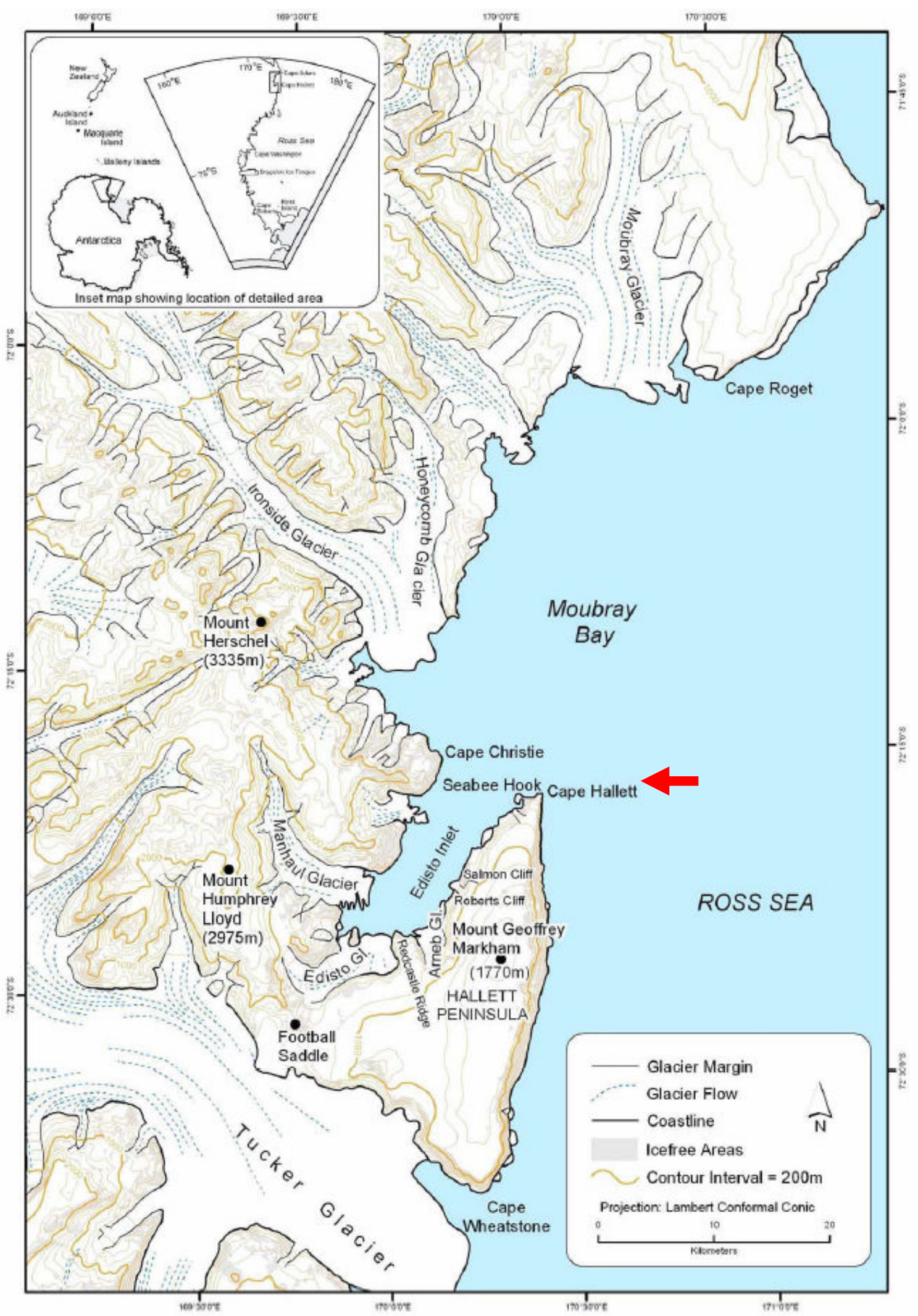

Figure 2.1 Detail of Hallett Peninsula (Gordon, 2003) 


\subsection{Epifluorescence microscopy}

An accurate and efficient assessment of bacterial abundance in natural environments has been a long-standing endeavour for aquatic microbial ecologists (Sherr et al., 2001). Determining both the abundance and biomass of microscopic cells are key parameters in aquatic ecosystems, and in virtually all studies of planktonic systems they are seen as the most essential measurements (Gasol and DelGiorgio, 2000). Early approaches to the enumeration of bacterial cells were based on the ability of cells to form colonies on marine agar plates (Sherr et al., 2001). This necessitated incubation periods of several days, but more importantly the plate count method detects only those bacteria capable of forming colonies on specific culturing medium (Bunthof and Abee, 2002); even the least specific media are selective with respect to total cell numbers in a sample (Monfort and Baleux, 1992, Porter et al., 1995). Referred to as the 'plate count anomaly' this approach resulted in a loss of observable species diversity and yielded significantly low estimates of bacterial abundance. Inaccuracies were in the order of $10^{2}$ to $10^{4}$ cells per ml. Although there has since been significant improvement in cell culture technique (Staley et al., 2001), the development of direct count methods using fluorescence microscopy and fluorescent stains was a revolutionary development in marine microbiology (Cole, 1999; Sherr et al., 2001).

A fluorescence microscope is essentially a compound microscope and the optical paths for image formation are similar to those of a standard bright field microscope (Taylor and Salmon, 1989). The observation of fluorescence is based on the ability to separate the light used to excite a specimen from the fluorescent light subsequently emitted. This can be achieved via two methods: (1) transmitted-light fluorescence 
microscopy, or (2) incident-light or epi-illumination fluorescence microscopy. Key components of the epi-illumination method are shown in Figure 2.2. In this system only one lens, the objective, is used to both focus the excitation light and to collect the fluorescent light emitted from the specimen (Ploem, 1989). As the objective also acts as the condenser, only one optical path to the detector is needed (Li et al., 2004a). The methods are further distinguished by the use of a dichroic mirror that is designed with an interference coating that is highly reflective when aligned at $45^{\circ}$; short wavelength excitation light is reflected, but the longer wavelength fluorescent light is transmitted. The development of the dichroic mirror was a major advantage of epifluorescent microscopy over transmitted-light fluorescence microscopy as it allows fluorescence to be combined with traditional transillumination methods such as phase contrast, polarisation, and differential interference contrast (Taylor and Salmon, 1989).

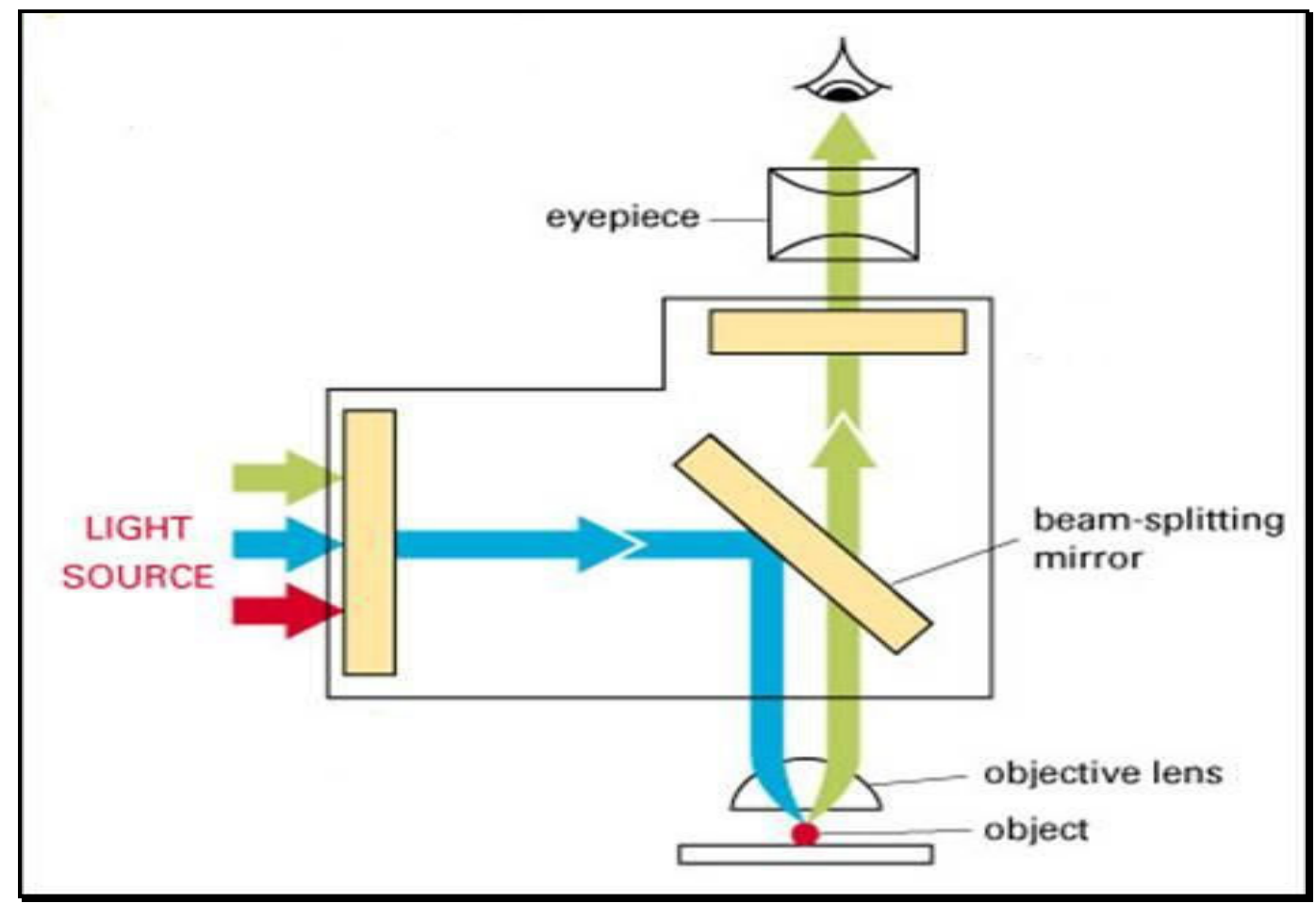

Figure 2.2. Schematic diagram of microscope for epi-illumination (Taylor and Salmon, 1989) 
The use of fluorescence to accentuate objects is based on the property of some atoms and molecules to absorb light and subsequently emit light that differs in wavelength from that initially absorbed (Ploem, 1989). When exposed to light of a particular wavelength, each fluorescent molecule will absorb a photon of energy. This energy excites an electron to adopt a higher orbital or vibrational state. During the return of the electron to its ground state, a photon is lost to the environment as fluorescence. Because this process involves the loss of energy, the emitted light is always of a longer wavelength and of a lower intensity than that initially absorbed (Li et al., 2004a).

Fluorochromes can be classified into two groups according to their functional characteristics. The first group targets specific cell components such as nucleic acids, lipids, or the cell membrane (Li et al.2004a). Commonly used dyes in the first group that stain DNA or RNA include acridine orange (AO), ethidium bromide, propidium iodide (PI) and 4',6 - Diamidino-2-phenylindole dihydrochloride (DAPI), while fluorescein isothiocyanate (FITC) is often used in conjugated forms for protein analysis. The second group of fluorochromes is used to assess the physiological state of individual cells and forms two broad categories: Those that indicate the state of cell membrane integrity or energisation, and those such as 5-Cyano-2,3-ditolyl tetrazolium chloride (CTC) and carboxyflourescein diacetate (CFDA) that are taken up by viable cells and then modified intracellularly to yield fluorescent products (Gasol and del Giorgio, 2000). 


\subsection{Flow cytometry}

The enumeration of bacteria entered a new phase with the application of flow cytometry. Although the basic elements of flow cytometry were developed three decades ago (Shapiro, 1995), the use of this technology in aquatic microbial ecology has been slow relative to other fields (Gasol and Del Giorgio, 2000). Flow cytometry can be broadly defined as a system for measuring, and then analysing, the signals that result as particles flow in a liquid stream through a beam of light (Givan, 2001). The technique is unique in that it allows quantitative measurements of individual cells in large numbers to be performed in a short time. Because the traditional microscopic techniques do not lend themselves to large-scale studies such as oceanographic cruises, analysis and enumeration of natural planktonic bacteria by flow cytometry is becoming an essential technique in aquatic microbial studies (Gasol and Del Giorgio, 2000).

There are three components to flow cytometers: a fluidics system to introduce and present cells for analysis; an optical system to collect light signals generated as cells pass through the laser; and an electronics system to convert the light signals to proportional electronic signals that are then digitised for computer analysis (Becton Dickinson).

\subsubsection{Fluidics system}

In order to obtain accurate measurements it is important that all particles of interest pass through a point of uniform sensitivity within the cytometer (Pinkel and Stovel, 
1985). This is accomplished by hydrodynamic focusing or sheath flow, a technique in which the sample fluid containing the cells of interest is injected into the central portion of a flowing stream of cell-free sheath fluid (Shapiro, 1988). The sheath fluid reservoir is pressurised by a built-in air pump in order to drive the sheath fluid through a filter to remove extraneous particles, and then through plastic tubing to the lower part of the flow cell (Givan, 2001).

Sheath flow is created by the conical shape of the lower flow cell chamber and when a sample is applied to the sample injection port (SIP), it is drawn up and injected into the lower chamber of the flow cell by a slight differential overpressure relative to the sheath fluid. The use of sheath flow confines cells to the central region of the stream which both increases the precision with which the cell sample can be positioned within the flow cell, and limits the likelihood of obstructions within the flow system (Shapiro, 1988). Sheath flow is further advantageous in that there is little mixing of sample with sheath fluid as the cells to be measured are carried in single file through the centre of the flow cell (Figure 2.3).

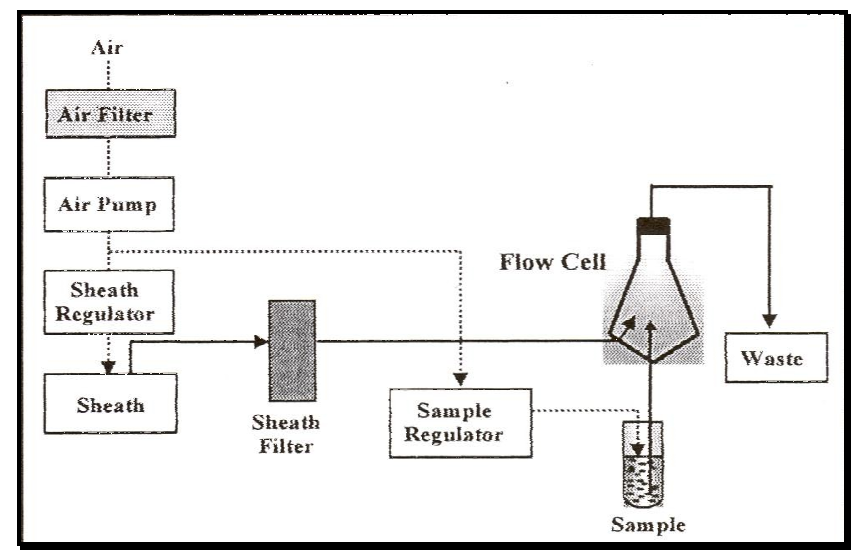

Figure 2.3. Schematic diagram of cytometer fluidics design (BD FACSCalibur model, Becton Dickinson). 


\subsubsection{Optical system}

Flow cytometric analysis is based on the generation of signals by illumination of particles passing a defined point within the flow cell. The source of illumination is either an arc lamp or a laser (Givan, 2001). The most popular lasers are argon ion lasers, typically air-cooled and run at a wavelength of 488nm (Shapiro, 1988). This means of illumination offers extremely high radiance, stability, and is a light source that can be focused on areas equal to the dimensions of cells (Wheeless and Kay, 1985).

The generated laser beam diverges little and provides an intensely bright, narrow beam allowing particles flowing past the laser to be illuminated strongly for a very short time. Signals from one particle can then be generated and subsequently separated by darkness from signals generated by the following particle (Givan, 2001). The laser beam is first passed through a prismatic beam expander that alters it from a circular profile to an elliptical distribution. A single element lens is then used to focus the expanded beam on the sample stream within the flow cell; dimensions of the laser profile at the focus point are typically $22 \mu \mathrm{m}$ vertically, and $66 \mu \mathrm{m}$ horizontally. Before the laser light enters the flow cell a final filter or beam-steering plate is used to align the light with the sample stream. When the laser beam strikes the plate the light is shifted a finite distance, parallel to its original path. Optimal laser alignment within the flow cell is achieved by rotation of the steering plate in either direction (Becton Dickinson), which ensures that the core of the sheath stream is uniformly illuminated by the light (Givan, 2001). 


\subsubsection{Detection optics}

The point at which the sheath stream and laser beam intersect is referred to either as the analysis point, observation point, or interrogation point. Surrounding this focal point within the flow cell are lenses that collect the photons of light scattered as cells pass through the laser beam (Givan, 2001). The photodetectors that collect the light signals and convert them into electrical impulses are either photodiodes or photomultiplier tubes.

The first element of the detection system is a silicon photodiode for the collection of forward scatter (FSC or FALS) laser light; light of the same colour as the illuminating beam that has been bent at a small angle, typically $1-10^{\circ}$, relative to the laser light (Givan, 2001). A laser-blocking bar positioned in the plane of the laser beam is necessary to separate the light scattered or diffracted by the cells from the unscattered light (Becton Dickinson). Forward scatter is proportional to cell surface area, volume, relative cell size, and refractive index (Givan, 2001; Jochem, 2000; Gasol and del Giorgio, 2000).

In addition to the collection of forward scatter light, three, four, or more photomultiplier tubes are positioned at right angles to the illuminating beam. A photomultiplier is a very sensitive detector of radiant energy in the ultraviolet, visible, and near infrared regions of the electromagnetic spectrum (Hiebert and Sweet, 1985) and therefore advantageous in detecting the weaker signals emitted at $90^{\circ}$ relative to the laser. Fluorescence emission and wide-angle scatter are initially collected by an objective lens that is optically coupled to the flow cell by a static surface of silicon 
gel. These signals will be a mixture of light of the same colour as the laser beam, and various other colours depending on the fluorescent stains or endogenous molecules associated with the cell (Givan, 2001). Because the various photomultipliers are insensitive to the wavelength of light they are exposed to, filters are required to enable the recording of colour specific responses.

Following the objective lens is a series of dichroic mirrors that separates the emitted light in discrete wavelength bands to the FL2 and FL3 detectors (Figure 2.4). Directly after the first dichroic mirror is a Brewster-angle beam splitter which is used to transmit unpolarised green fluorescent light to the FL1 detector, while reflecting the vertically polarised laser light to the side scatter detector (Becton Dickinson). Further spectral sensitivity is achieved by placing both a slit filter and a band-pass filter in front of each photomultiplier tube. The band-pass filter transmits only a narrow wavelength, while the slit filter prevents background light from reaching the detector (Becton Dickinson).

The intensity of side scatter light (SSC or WALS) is related to cell surface texture and internal structure, as well as size and shape (Givan, 2001; Jochem, 2000; Gasol and del Giorgio, 2000). This is light of the same colour as the illuminating beam that is scattered by a particle to an angle of $90^{\circ}$ relative to the illuminating beam (Givan, 2001). The remaining photomultipliers (the number of which depends on configuration) are used to collect either the fluorescence emission of any fluorochromes associated with the cell, or the naturally occurring fluorescence of endogenous molecules within the cell, if they are of interest (Figure 2.4). 


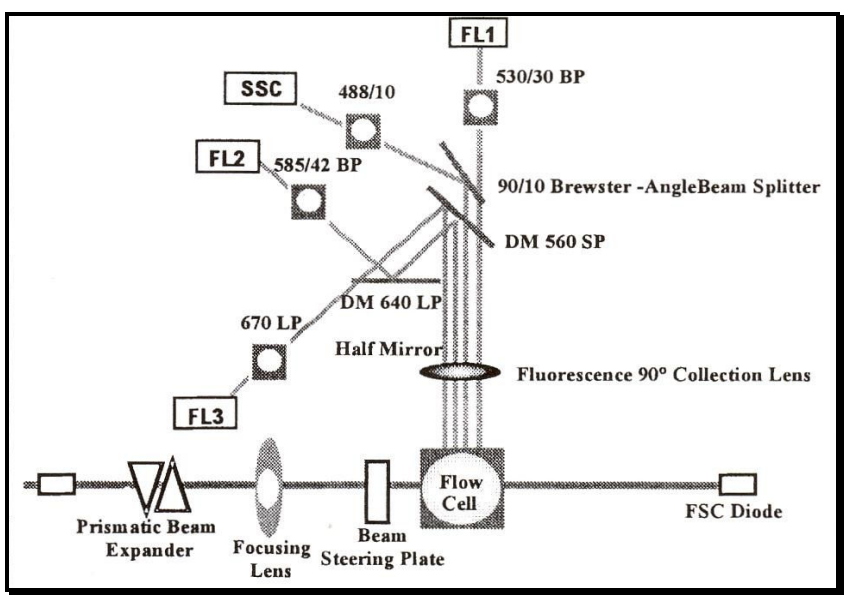

Figure 2.4 Schematic diagram of cytometer optical design (BD FACSCalibur model, Becton Dickinson).

\subsubsection{Electronics system}

The small electrical impulses (analog signal pulses) generated by the response of photodetectors to the detection of photons of light are then digitised. Further influence over the response to light is achieved by changing the amplification of the electrical current after it leaves the photodetector. This amplification can be either linear or logarithmic to cater for the expected range of signals and can operate at varying gains. Logarithmic transformation of cell signals is useful if cells exhibit a range of fluorescence intensities and compression increases the dynamic range of the system (Hiebert and Sweet, 1985). If there is less than a 10-fold difference between the smallest and largest signal, as is typical in DNA content studies (Givan, 2001), then linear amplification is sufficient. 
Once the electrical signal from a photodetector has been amplified, an analog-todigital converter (ADC) is used to group the continuous distribution of signals into discrete ranges (Givan, 2001). Finally, this digital information is transferred from the flow cytometer to a computer where the classification of results can be processed and displayed with the appropriate software.

\subsection{Filtration}

Two filtration systems were briefly compared to determine bacterial cell abundance. Initially, samples were pressure filtered using a disposable syringe and Millipore Swinnex filter holders. In this configuration liquids were dispensed by syringe to the top of the plastic Swinnex unit and the cells were collected on internally mounted $25 \mathrm{~mm}$ membranes as the sample was gently forced through the filter. This method proved useful for filtering small volumes, but was less efficient for larger sample sizes. The distribution of cells observed on the filter membranes appeared to be uniform, but the pressure system may have resulted in a greater concentration of cells in the middle of the membrane and biased cell counts.

The method subsequently adopted for all sample filtration was to collect cells using a vacuum operated filter apparatus (Millipore). This method is consistent with the current literature on microbial analysis. The sample was placed in a glass funnel and filtered through a membrane placed between the funnel and underlying vacuum flask. When combined with a $0.8 \mu \mathrm{m}$ backing filter, this system was highly effective in establishing a uniform distribution of cells on the target membrane. 


\subsection{Filtration Membranes}

Membranes suitable for filtration are constructed from a range of materials and cater for a variety of applications. The majority of recent studies involving the enumeration of bacterial cells with epifluorescent microscopy utilise $0.22 \mu \mathrm{m}$ black-stained polycarbonate membrane filters (e.g. Nucleopore, Poretics). It has been suggested that a black background significantly enhances the degree to which fluorescently labelled cells can be visualised and that the polycarbonate construction captures more cells (Cole, 1999). During the course of this research both black polycarbonate filters (Poretics) and white mixed cellulose ester membranes (Millipore) were trialled. Although differences in colour and construction were not empirically determined, the use of white cellulose-based membranes did not significantly impede cell counts and were easier to handle in field conditions.

Despite careful use of the vacuum pump, the formation of holes in the central region of both filter types was occasionally observed. The prevalence of holes, and therefore loss of cells, was notably greater in the polycarbonate construction, and for this reason $0.22 \mu \mathrm{m}$ white cellulose membranes were used for all experiments.

Three different vacuum pumps were used at various stages of the research, only one of which was capable of airflow calibration. In order to minimise the need to repeat sample filtrations due to holes being formed in the membranes, the vacuum created by each pump was carefully controlled by manually restricting air- flow to the vacuum flask. 


\subsection{Antifade}

The prevention of photobleaching was found to be a requirement for all sample slides in order to maintain fluorescence during cell counts. This was despite accounts that the fluorochrome DAPI does not fade while a field of view is being examined (Sherr et al., 2001). Two antifade products were used. Initially, a mounting medium using 1,4 - Diazabicyclo [2.2.2] octane or DABCO ${ }^{\mathrm{TM}}$ (Sigma) was used which acts by scavenging the free radicals produced by fluorochrome excitation. This was made up as follows:

$0.2 \mathrm{~g} \mathrm{DABCO}$ in $9 \mathrm{ml}$ glycerol heated to $50^{\circ} \mathrm{C}$.

Add to this $1 \mathrm{ml}$ of the following solution:

10ml 1m TRIS, pH 7.4

$40 \mathrm{ml} \mathrm{DDH}{ }_{2} 0$

10mg sodium azide.

This antifade medium was observed to have a variable influence on the degree of photobleaching but was adequate provided cells were counted as quickly as possible once exposed to UV excitation light. In the latter experiments the commercial product VECTASHIELD (Vector Laboratories) was used. Although designed for a specific range of fluorochromes such as Texas Red and $\mathrm{Cy} 3$, this medium was much better than the earlier method in preserving DAPI fluorescence. 


\subsection{Treatment of ethanol preserved samples}

The samples collected from the Mertz Glacier in 2002 were preserved in ethanol at a final concentration of $10 \%$. This proved to be highly problematic in sample filtration as sodium chloride crystals developed in the samples and this prevented even small volumes $(0.5 \mathrm{ml})$ passing through a filter membrane. Several options were considered to remedy this problem including dialysis and DAPI-staining of small volumes of sample directly onto glass slides. The simplest method, and that finally adopted, was to add sterile, double distilled water to each sample. Although this significantly increased the time needed to filter each sample, it was an effective means of redissolving the sodium chloride crystals.

Several steps were taken to ensure the added water was cell-free. This entailed firstly autoclaving small quantities of water before filtering them through a $0.22 \mu \mathrm{m}$ Millipore filter. This filtrate was then autoclaved a second time to kill any remaining bacterial spores. On occasion however, live cells were viewed on the membrane surface of some slides and while such cells were not counted, a degree of error in overall cell counts using this method must be assumed. 


\subsection{Bacterial cell stains}

\subsubsection{4',6 - Diamidino - 2 - phenyindole hydrochloride (DAPI)}

DAPI is a general fluorescent stain that complexes to A-T rich sequences in the major grove of DNA in bacterial cells (Howard-Jones et al., 2001). This stain has been used at final concentrations ranging from $0.01 \mu \mathrm{g} \mathrm{ml}^{-1}$ to over $10 \mu \mathrm{g} \mathrm{ml}^{-1}$ (See Sherr et al., 2001). In order to determine an appropriate staining regime, seawater samples from Wellington Harbour were stained at $0.01 \mu \mathrm{g} \mathrm{ml}^{-1}$ final concentration at the following volumes: $25 \mathrm{ml}, 50 \mathrm{ml}, 100 \mathrm{ml}, 200 \mathrm{ml}, 300 \mathrm{ml}$. Each sample was filtered through a membrane until 10ml remained in the glass funnel before DAPI was added. After an incubation period in the dark the remaining fluid was filtered. Samples were examined under an epifluorescence microscope to determine whether increases in the volume of seawater filtered (and therefore bacterial cells) correlated with increases in the number of stained bacterial cells. Staining at the lower concentration of $0.01 \mu \mathrm{g} \mathrm{m}{ }^{-1}$ did not appear to limit the number of cells stained across the range of volumes trialled and produced low background fluorescence.

\subsubsection{5-cyano-2,3-ditolyl tetrazolium chloride (CTC)}

CTC is a monotetrazolium redox dye that produces a fluorescent formazan (CTF) when chemically or biologically reduced. CTC has become a popular stain for determining metabolic activity in bacteria and coupled with DAPI staining indicates the presence of both active and total cells. 
In preparation for use in Antarctic field conditions, samples of seawater from

Wellington Harbour were stained with CTC and subsequently counterstained with DAPI. Prior to counterstaining, a fixative is required to suspend all cell activity. Both glutaraldehyde and formalin were investigated for this purpose. The staining affinity of DAPI proved to be ineffective in the presence of glutaraldehyde, but was found to be successful if cells were fixed in formalin.

\subsubsection{6-Carboxyfluorescein diacetate (CFDA)}

A second metabolic stain 6-Carboxyfluorescein diacetate (CFDA) was also considered for use at the Cape Hallett field camp. Some success was achieved in trials with this stain, but the protocols described in the literature required use of a microcentrifuge, which was not subsequently available at the remote Antarctic field site.

\subsection{Flow cytometry calibration}

Preliminary investigations were conducted using a Becton Dickinson FACScan Flow Cytometer at Victoria University, Wellington. In order to produce accurate cell counts it is necessary to determine the volume processed by the cytometer for each sample. The calibration method chosen was to use Becton Dickinson TruCount tubes (cat\# 340335) in conjunction with $1.0 \mu \mathrm{m}$ microspheres (Polysciences cat\# 18860).

Calibrations were run in triplicate, as described in Crain (2003). 
Two fluorochromes were compared in analysing the Mertz Glacier samples:

a) Propidium iodide (PI) passively diffuses into cells that have lost membrane integrity and binds to both RNA and DNA. PI is commonly used for identifying dead cells in a population, provided they have been permeabilised.

b) SYBR Green I (Molecular Probes) is a nucleic acid stain with a high binding affinity for RNA or double-stranded DNA. The staining protocol used was that described in Crain (2003).

Both fluorochromes produced spurious data. Efforts made to validate the technique included stain dilution, examination of E.coli cells, consideration of sheath fluids, and trials to determine the influence of ethanol as a preservative. The Becton Dickinson FACSCalibur cytometer operated by the Malaghan Institute, Wellington, provided a comparison of machines and similar results were obtained with this machine. Success in analysing both the Mertz Glacier and Cape Hallett samples was achieved using the NIWA FACSCalibur cytometer in Hamilton and the nucleic acid stain SYBR Green II (Molecular Probes). Flow calibration was acquired using BD TruCount tubes (cat\# $340334)$. 


\subsection{Wellington Harbour pilot study}

\section{Introduction}

Estimating the abundance of aquatic bacteria is an important parameter in microbial ecology. A short pilot study was conducted in Wellington Harbour to gain familiarity with sample filtration, slide preparation and the estimation of cell abundance using epifluorescence microscopy. Three sampling sites within Wellington Harbour were chosen to compare possible differences in bacterial cell abundance. Moa Point and Island Bay were selected on the south coast to contrast the possible influence of the nearby $(2 \mathrm{~km})$ sewage outlet at Moa Point, while the Hutt River estuary was chosen to compare cell counts in an area of the harbour with fluctuating saline concentrations and high sediment input. It was expected that Moa Point will support a greater number of bacteria compared to the estuarine conditions at the mouth of the Hutt River.

\section{Methods}

Seawater samples of approximately 1 litre were collected from Wellington Harbour in March 2003 from Moa Point, Island Bay and the Hutt River Estuary. Samples were collected from the shoreline in plastic bottles irrespective of local tide levels.

A Millipore filtering apparatus was used to carefully vacuum-filter three $100 \mathrm{ml}$ subsamples from each site onto internally mounted $0.22 \mu \mathrm{m}$ white Millipore cellulose membranes, $25 \mathrm{~mm}$ in diameter and with a pore size of $0.22 \mu \mathrm{m} .90 \mathrm{ml}$ of each subsample was passed through the membrane before DAPI was added to the remaining 
$10 \mathrm{ml}$ in the filter tower at a final concentration of $0.01 \mu \mathrm{g} \mathrm{ml}^{-1}$. The filtering apparatus was placed in the dark and left for twenty minutes.

After this time, the remaining $10 \mathrm{ml}$ was filtered and the membrane carefully removed with tweezers and placed on a glass slide. A drop of DABCO-based mounting medium was placed on the membrane before a cover slip was overlain and sealed with nail polish.

Cells were counted on an Olympus microscope under 1000x magnification using oil immersion. Slides were visualised using a digital camera mounted to the microscope with images relayed to a monitor. For each slide 3 fields of view were randomly selected and counts were made either of a complete field of view, or the number of cells occurring in one quarter of the field of view. The number of cells present for each sub-sample was calculated by determining the area of the filter paper, number of possible fields of view at 1000x magnification as seen through a monitor and multiplying this by the number of cells counted. This result was appropriately scaled to provide an estimate of the number of cells per $\mathrm{ml}$ in each sub-sample. Differences between sampling locations were determined using a two-sample $t$ significance test.

\section{Results}

Differences between cell abundance at each site within Wellington Harbour are shown in Figure 2.5. The number of bacterial cells at Moa Point and the Hutt River were similar at $48 \times 10^{4}$ and $50 \times 10^{4}$ cells per $\mathrm{ml}$ respectively $(t=0.12, \mathrm{df}=2, \mathrm{p}>0.25)$. The data suggest far fewer bacteria are present in the water at Island Bay, with on average 
$17 \times 10^{4}$ cells per $\mathrm{ml}$. This is significantly less than either Moa Point $(\mathrm{t}=11.90, \mathrm{df}=2$, $\mathrm{p}<0.005)$, or the Hutt River $(\mathrm{t}=1.97, \mathrm{df}=2, \mathrm{p}<0.1)$. In relation to sampling site, the counts obtained for each replicate show good similarity with the exception of one Hutt River replicate. Relatively small standard errors suggest an even distribution of cells on the filter membranes using the vacuum method for filtration. For the Hutt River replicates the error bars represent, on average, a $4.33 \%$ departure from the mean, while for Island Bay and Moa Point the figures are $4.67 \%$ and $4.00 \%$ respectively.

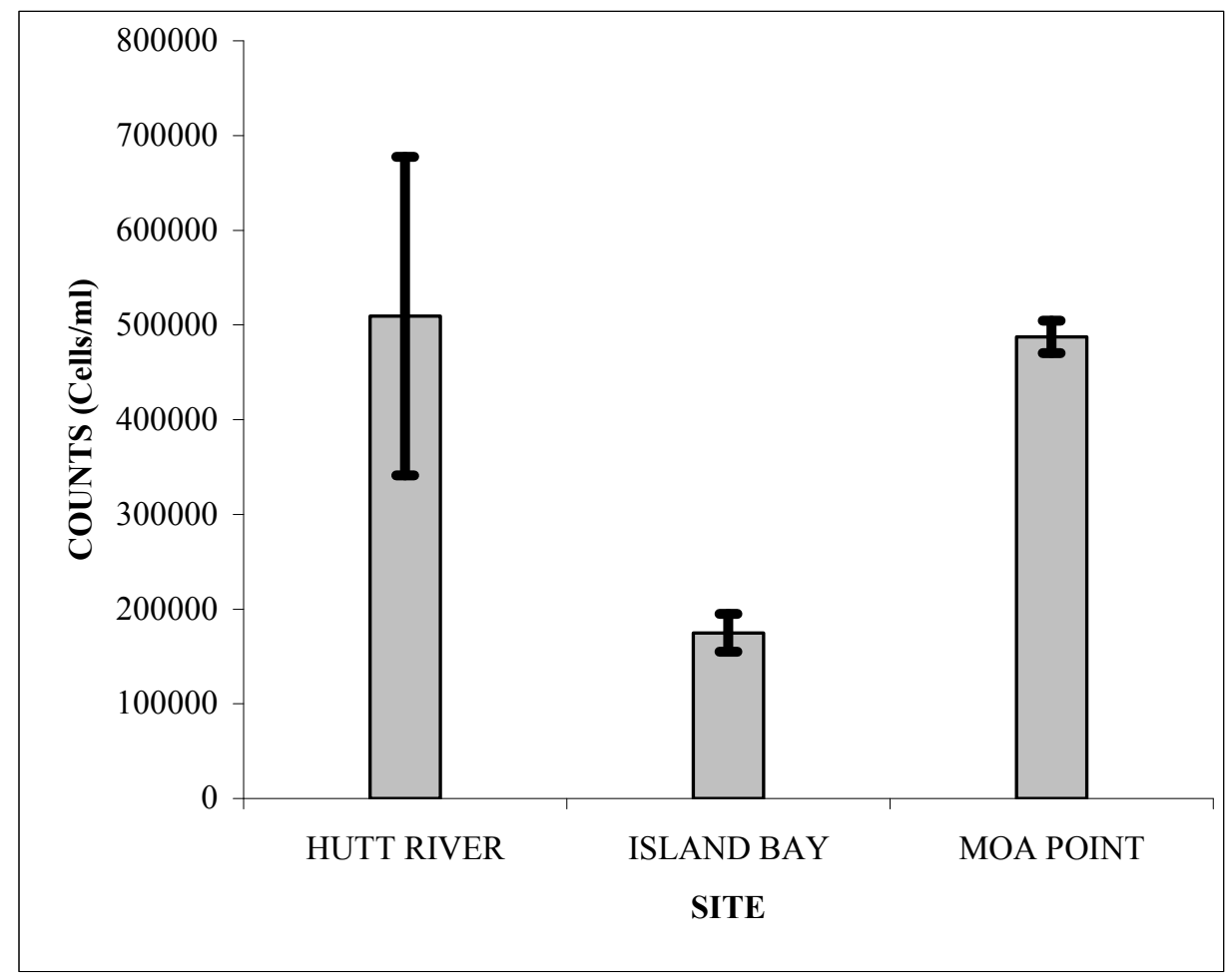

Figure 2.5 Comparison of the abundance of bacterial cells from three locations within Wellington Harbour. Error bars are \pm 1 SE. 


\section{Discussion}

While the scale of this pilot study was not intended to provide meaningful conclusions in comparing sampling sites, the abundance of bacterial cells around the Wellington coastline does not appear to be uniform. While the abundance of cells at Moa Point proved to be significantly greater than Island Bay, the Moa Point count average is comparable with the Hutt River sampling site which was initially postulated to be the least favourable environment for bacterial growth. The Hutt River average is heavily influenced by one replicate however, which has not been excluded as an outlier. The lower cell abundance observed at Island Bay may simply reflect error in sample collection, although the data suggest there are significant differences in bacterial abundance within Wellington Harbour that could be explored further. 


\title{
Chapter 3: Distribution and abundance of sea ice bacteria from two locations in coastal Antarctica and evidence for the microbial loop
}

\begin{abstract}
Diverse microbial communities are present in the brine inclusions and interstices of Antarctic sea ice that are integral to the energy base of the Southern Ocean.

Productivity in Antarctica reflects both the spatial and temporal dynamics of annual sea ice, as well as the complex cycling of energy through the sea ice microbial community. Marine bacteria are thought to be integral to trophodynamics and functioning of a microbial loop within the ice matrix, but there is currently no clear understanding of the distribution and diversity of sea ice bacteria. In this study, a multivariate statistical approach was used to compare the distribution and abundance of bacteria occurring in pack ice at the tongue of the Mertz Glacier (George V Coast, Antarctica) with bacteria from fast ice at Cape Hallett (Victoria Land coastline, Antarctica). Epifluorescence microscopy was compared with flow cytometry as methods for assessing bacterial cell numbers, while regression analysis was used to examine how bacteria covaried with algae and $\mathrm{Chl} a$ at each location. Flow cytometry proved to be a more robust method for providing cell estimates and was used for all analyses. There was no difference in the abundance of bacterial cells with respect to sampling location, but a significant difference in the vertical distribution of cells within the ice was observed. Cell numbers for bacteria and algae were positively correlated in pack ice of the Mertz Glacier indicating a functional microbial loop, but exhibited no discernable relationship in fast ice at Cape Hallett. These findings
\end{abstract}


support the general consensus that the generation of bacterial biomass from algalderived dissolved organic matter is highly variable across seasons and habitats.

\subsection{Introduction}

Productivity in the Southern Ocean is characterised by large-scale spatial and temporal variability. This is largely due to the annual expansion and contraction of sea ice around the Antarctic continent that influences not only the pelagic systems under the ice, but enhances ecological variability and productivity of the ice-bound biota (Legendre et al., 1992; Ackley and Sullivan, 1994). Although sea ice represents a harsh physicochemical environment with steep gradients in temperature, light, salinity, and nutrient concentrations (Arrigo and Sullivan, 1992), diverse microbial communities are present in the brine inclusions and interstices of sea ice that are integral to the energy base of the Southern Ocean (Garrison, 1991). Marine bacteria are an important component of the sea ice community but there is no clear understanding of the distribution and diversity of bacteria, or how this relates to community processes, particularly Southern Ocean carbon cycling (Ducklow et al., 1999).

Current climate models predict a $25-45 \%$ reduction in the volume and extent of annual sea ice over the coming decades and forecast long-term changes to the physical oceanography and ecology of the Southern Ocean (Wu et al., 1997; Gordon and O'Farrell, 1997). While the effect of climate change on sea ice dynamics and productivity within the Antarctic sea ice ecosystem is not well understood, there are thought to be significant ecological consequences to changes in the magnitude and 
timing of seasonal sea ice advance and retreat (Smith et al., 1998). This has renewed interest in understanding the constraints on microbial abundance, activity, and survival in polar regions.

In most regions of Antarctica, ice-cover is an annual phenomenon that can be divided into a zone of fast ice that remains attached to the shoreline, and free-floating pack ice which extends into deep-water regions (Vincent, 1988; Garrison, 1991; Ackley and Sullivan, 1994). Both ice environments support numerous algal, bacterial and protistan species (Arrigo and Sullivan, 1992). While the presence of ice dictates the spatial and temporal variability of microbial communities, productivity reflects a complex of physicochemical characteristics including temperature, presence of snow, distribution of organic and inorganic nutrients and photosynthetically active radiation (PAR) (e.g. Palmisano et al., 1987; Priscu et al., 1989; Sullivan et al., 1990; Cota et al., 1990; Garrison and Buck, 1991).

Descriptions of the distribution and abundance of bacteria with respect to ice structure however, remain fragmentary (Delille, 1992). The majority of studies examining sea ice have focused on fast ice that constitutes only $1-5 \%$ of the seasonal ice cover. The highest biomass and production of microbes occurs in microhabitats at the base of fast ice (Archer et al., 1996), and metabolic coupling between bacterial growth and microalgal photosynthetic metabolism has been well documented (e.g. Sullivan and Palmisano, 1984; Grossi et al., 1984; Kottmeier et al., 1987; Stewart and Fritsen, 2004). The vast majority of Antarctic sea ice is pack ice, which supports a microbial biomass concentrated in interstitial and surface layers (Archer et al., 1996; Garrison et al., 1986). Pack ice communities are thought to contribute the majority of the sea ice 
carbon production in ice-covered regions of the Southern Ocean. However, due to limited accessibility there is much less known about the diversity, distribution or abundance of pack ice microbial communities (Kottmeier and Sullivan, 1990; Legendre et al., 1996).

Observed bacterial abundance and level of in situ activity has led several authors to propose an active microbial loop operating within sea ice, similar to that of temperate systems (Sullivan and Palmisano, 1984; Azam et al., 1991). The links between bacterial processes and higher trophic levels within the microbial loop are not well defined. The microscopic fraction of the sea ice community is known to be an important food source for crustaceous zooplankton such as the Antarctic krill Euphausia superba Dana (Daly, 1990; Stewart and Fritsen, 2004; Kottmeier and Sullivan, 1990), but little is known about the exact trophic relationships between these organisms or rates of carbon transfer (Cota et al., 1990; Stewart and Fritsen, 2004). Additionally, bacteria are thought to facilitate algal-based primary production within sea ice by providing microalgae with the remineralised nutrients necessary for continued growth (Kottmeier and Sullivan, 1990; Kottmeier et al., 1987; Archer et al., 1996). In return, bacteria make use of exuded algal photosynthate and are subsequently consumed by nanoplankton and microzooplankton such as flagellates and ciliates. This process may cycle as much as a $20-30 \%$ of the ice-bound primary production to higher trophic levels (Staley et al., 2002). The assimilation by bacteria of algal-derived dissolved organic matter (DOM) is a core process in the microbial loop hypothesis, but remains equivocal with respect to the spatial and temporal dynamics of the sea ice ecosystem (Ducklow et al., 1999; Stewart and Fritsen, 2004). 
The abundance and biomass of microscopic cells are key parameters in aquatic ecosystems, and in virtually all studies of planktonic systems these are the most essential measurements (Gasol and DelGiorgio, 2000). A long-standing endeavour of aquatic microbial ecology has been to achieve an accurate and efficient assessment of bacterial abundances in natural environments. Early approaches to the enumeration of bacteria were based on the ability of cells to form colonies on marine agar plates. However this method detects only those bacteria capable of forming colonies on specific culturing medium (Bunthof and Abee, 2002); even the least specific media are selective with respect to total cell numbers in a sample (Monfort and Baleux, 1992, Porter et al., 1995).

Although the implementation of direct count methods using fluorescence microscopy was an important development in microbiology (Cole, 1999; Sherr et al., 2001), the enumeration of bacteria has been revolutionised with the application of flow cytometry. The application of this technology in aquatic microbial ecology has been slow relative to other fields (Gasol and Del Giorgio, 2000), even though the traditional microscopic techniques do not lend themselves to large-scale studies such as oceanographic cruises. Flow cytometry confers significant advantages over fluorescence microscopy, including quantitative measurements of individual cells, simultaneous multiparameter analysis, adequate sensitivity of small organisms $\left(<0.1 \mu \mathrm{m}^{3}\right)$ and robust statistics due to analysis rates in the order of $10^{4}$ cells per minute (Robertson et al., 1998). Because of these advantages, analysis and enumeration of natural planktonic bacteria by flow cytometry is now becoming an essential technique in aquatic microbial studies (Gasol and Del Giorgio, 2000). 
The Victoria Land mountain chain and coastline within the Ross Sea region contains the most extensive latitudinal gradient in Antarctica, ranging from Cape Adare $\left(68^{\circ} \mathrm{S}\right)$ in the north to the southern end of the Ross Ice Shelf $\left(86^{\circ} \mathrm{S}\right)$, and includes a variety of marine, terrestrial and freshwater habitats. Important environmental factors including solar radiation (annual PAR, UV radiation), temperature, day length and sea ice cover vary predictably along this gradient and are likely to exert a significant influence on ecological processes (Howard-Williams and Peterson, 1998). The Latitudinal Gradient Project (LGP), which is a cooperative research programme that commenced in the 2003/2004 Antarctic field season, aims to develop an understanding of the ecosystems that exist along the Victoria Land coastline and to describe the potential environmental variability that may occur in the future (Gordon, 2003).

This paper examines sea ice bacteria from two distinct sites off the coast of Antarctica. The distribution and abundance of microbes occurring in pack ice at the tongue of the Mertz Glacier off the George V Coast $\left(66^{\circ} \mathrm{S}\right)$ is compared with the microbial community from fast ice at Cape Hallett (the first LGP site) on the Victoria Land coastline $\left(72^{\circ} \mathrm{S}\right)$. In addition to comparing methods for assessing bacterial cell numbers, a multivariate approach is used to examine the bacteria/algae associations at each location. Specifically, three questions are addressed:

(1) How does the use of flow cytometry compare with epifluorescence microscopy for determining bacterial cell abundance?

(2) Does the distribution and abundance of sea ice bacteria differ between the Mertz Glacier (pack ice) and Cape Hallett (land-fast ice)?

(3) Does the bacteria/algal relationship at both locations indicate an active microbial loop? 


\subsection{Methods}

\subsubsection{Sample collection}

\section{Mertz Glacier}

Sea ice microbial assemblages were collected from pack ice at the edge of the Mertz Polyna $\left(66^{\circ} \mathrm{S}, 147^{\circ} \mathrm{E}\right)$ in spring 2002 . Twenty ice core profiles (130mm diameter) were extracted using a SIPRE corer (Kovaks, U.S.A.) from eight sites visited by the Australian research vessel Aurora Australis between $29^{\text {th }}$ October and $8^{\text {th }}$ November. To prevent exposure to ambient surface radiation, extracted cores were immediately placed in black polythene bags when removed from the ice. Each core profile was cut into $100 \mathrm{~mm}$ increments as soon as possible following collection, and each section was melted in $50 \mathrm{ml}$ of filtered seawater chilled to $-1.8^{\circ} \mathrm{C}$ (Whatman $\mathrm{GF} / \mathrm{F}$ glass fibre filters, $0.45 \mu \mathrm{m})$. Subsamples from each melted section were used to determine total carbon, chlorophyll $a(\mathrm{chl} a)$ concentration and algal abundance. For bacterial analyses, $10 \mathrm{ml}$ from each section were fixed with ethanol (10\% final concentration) and stored at $4^{\circ} \mathrm{C}$.

\section{Cape Hallett}

At Cape Hallett, microbial assemblages were collected from fast ice approximately $1.5 \mathrm{~m}$ thick between $22^{\text {nd }}$ November and $12^{\text {th }}$ December 2003. Five sampling sites were established within a radius of $2 \mathrm{~km}$ of Seabee Hook. Each site was surveyed once in late November and then revisited in early December. During the first survey, three shallow holes were drilled at each site with a powered ice auger (Jiffey) prior to using a SIPRE corer to extract the bottom $400-500 \mathrm{~mm}$ of sea ice. In addition, a SIPRE corer 
was used to extract one complete core profile at each site. During the December survey, four $400-500 \mathrm{~mm}$ cores were extracted at each site. An opaque sheet was employed during all core removal to prevent cell exposure to ambient surface radiation.

Once clear of the ice, each core was transferred to a black polythene bag. Under low light conditions $\left(<1 \mu \mathrm{mol}\right.$ photons $\left.\mathrm{m}^{-2} \mathrm{~s}^{-1}\right)$, the bottom $100 \mathrm{~mm}$ of ice was cut from each core and then reshaped to form a block 40x40x100mm. For bacterial analysis either $2 \mathrm{~g}$ or $5 \mathrm{~g}$ of ice was carefully scraped off each block with a scalpel and melted in either $6 \mathrm{~g}$ or $15 \mathrm{~g}$ of filtered seawater $(0.22 \mu \mathrm{m}, 36 \mathrm{ppt})$ respectively. Samples were then fixed in paraformaldehyde (1\% final concentration) and glutaraldehyde $(0.05 \%$ final concentration). This process was repeated for the four complete profiles as described for the Mertz Glacier samples. All Hallett samples were kept as cold as possible (approx. $0^{\circ} \mathrm{C}$ ) and stored at $-80^{\circ} \mathrm{C}$ upon return to Wellington, New Zealand.

\subsubsection{Epifluorescence microscopy}

\section{Mertz glacier samples}

Prior to filtration, $30 \mathrm{ml}$ of sterile $0.22 \mu \mathrm{m}$ - filtered double-distilled water $\left(\mathrm{DDH}_{2} \mathrm{O}\right)$ was added to $1 \mathrm{ml}$ of each Mertz glacier sample to dissolve the ethanol-induced precipitation of sodium chloride. A Millipore filter apparatus was used to vacuumfilter each sample onto a white $25 \mathrm{~mm}$ diameter cellulose membrane filter (Millipore, $0.22 \mu \mathrm{m}$ ). Backing filters (Millipore, $0.8 \mu \mathrm{m}$ ) were used to ensure an even distribution of cells. Twenty $\mathrm{ml}$ was initially passed through the membrane before $4{ }^{\prime}, 6-$ 
Diamidino - 2 - phenyindole hydrochloride (DAPI) stain was added to the remaining $10 \mathrm{ml}$ in the filter tower at a final concentration of $0.01 \mu \mathrm{g} \mathrm{ml}^{-1}$. The filtering apparatus was placed in the dark for 15 minutes. After this time, the remaining $10 \mathrm{ml}$ was filtered, and the membrane removed and placed on a glass slide. A drop of VECTASHIELD (Vector Laboratories) mounting medium was placed on the membrane before a cover slip was overlaid and sealed with nail polish.

Cells were visualised on an Olympus Provis AX70 microscope using a UV filter set and 1000x magnification with oil immersion. For each slide, approximately 200 bacterial cells were counted, either as a series of randomly selected fields of view, or as one complete pass of the filter paper from edge to edge. The number of cells per ml was calculated by determining the area of the filter paper, number of fields of view/passes at 1000x magnification and multiplying this by the average/number of cells counted. This result was appropriately scaled to provide an estimate of the number of cells per $\mathrm{ml}$ and per $\mathrm{m}^{2}$ for each sample.

A recount of five of the samples was made several months after the initial count to determine the effects of storage and use of ethanol as a preservative.

\section{Cape Hallett samples}

Epifluorescence microscopy was used to estimate bacterial abundance for ten of the Cape Hallett samples (two samples from each site), as described above. As these samples were preserved with paraformaldehyde/glutaraldehyde it was not necessary to 
add $\mathrm{DDH}_{2} \mathrm{O}$. Cells were stained with DAPI at a final concentration of $5.0 \mu \mathrm{g} \mathrm{ml}^{-1}$ and incubated for ten minutes.

\subsubsection{Flow cytometry}

Prior to analysis, each Mertz Glacier and Cape Hallett sample was pressure-filtered using Swinnex filter holders (Millipore) with internally mounted 3.0 $\mu \mathrm{m}$ filter papers to remove the majority of algal cells. Each sample was prepared by pipetting $500 \mu 1$ of each sample into a flow tube followed by $25 \mu 1$ of SYBR Green II (Molecular Probes) working solution ( $4 \mathrm{ml}$ DMSO added to $50 \mu 1$ vial of SYBR Green II). Samples were vortexed briefly, and left in the dark for approximately five minutes. $50 \mu 1$ of TruCount solution ( $500 \mu 1 \mathrm{DDH}_{2} 0$ added to a Becton Dickinson TruCount tube) was added prior to running each sample.

All Mertz Glacier and Cape Hallett samples were analysed on a Becton Dickinson FACSCalibur flow cytometer equipped with a $15 \mathrm{~mW}, 488 \mathrm{~nm}$, air-cooled argon ion laser and standard filter setup. Initial instrument calibration was performed using FACScomp software in conjunction with Becton Dickinson CaliBRITE reference beads. The sheath fluid was $\mathrm{DDH}_{2} 0$. To avoid coincidence, samples were run on a medium flow rate with less than 1300 events per second. The sample flow was calibrated using Becton Dickinson TruCount beads. The event threshold was set at 340 on FL1.

Becton Dickinson CellQuest software was used for all sample and data analyses. Bacterial cell populations and TruCount beads were visualised on density plots of 
SSC Vs. FL1. Each sample was run twice using an acquisition template set to acquire 300 TruCount beads per run. CellQuest was subsequently used to perform a batch analysis on both the Mertz and Hallett data.

\subsubsection{Image analysis}

A Nikon Coolpix 995 digital camera mounted to an Olympus Provis AX70 microscope was used to take a series of digital images of DAPI-stained cells. For the Mertz Glacier samples, photos were taken of the cells present at each $100 \mathrm{~mm}$ section of one ice core profile in order to estimate bacterial carbon biomass and determine whether cell biovolume fluctuated with depth within the ice profile. Images were taken of cells present within the bottom $100 \mathrm{~mm}$ of each site at Cape Hallett to estimate carbon biomass and to provide a comparison of cell biovolume between sites.

Measurements of the cells present in the digital photos were carried out using SigmaScan Pro (SPSS) image analysis software. Each digital photo was initially converted to an 8 bits-per-pixel mono image and then an intensity threshold overlay was applied and calibrated to determine the best fit in relation to cell border. Measurements of cell length (major axis) and width (minor axis) were performed on approximately 150 cells from the Mertz glacier profile and 100 cells from the Cape Hallett sampling sites. 


\subsubsection{Calculation of biovolume (cell size)}

The majority of cells present in the Mertz samples had a rod-shaped morphology.

Thus, cell biovolumes were calculated using the following equation (Fry and Davies, 1985):

$V=\left(d^{2} \pi / 4\right)(1-d)+\pi d^{3} / 6$

where $1=$ cell length and $d=$ cell width .

This calculation makes the assumption that cell shape approximates a cylinder with hemispherical ends and that cell depth is equal to cell width. As the coccoid morphology was the predominant cell type at Cape Hallett, the formula for a prolate spheroid was used to calculate biovolume (Sherr et al., 2001):

$V=(\pi / 4) d^{2}(1-d / 3)$

To obtain an estimate of bacterial carbon biomass, the biovolume-specific formula of Simon and Azam (1989) was used:

$\mathrm{CC}=88.6 \times \mathrm{vol}^{0.59} \times 1.042$

where $\mathrm{CC}=$ average carbon content per cell $(\mathrm{fg})$ and vol = average cell volume. 


\subsubsection{Statistical analyses}

To compare counts made by flow cytometry and epifluorescence microscopy, data were initially log transformed (base 10) to obtain a normal distribution and then plotted to determine Pearson's correlation coefficient (r). For both the Mertz and Hallett datasets the significance of $r$ was tested to provide an appropriate $p$-value. Flow cytometry was found to be a more robust and accurate method of assessment and counts obtained using this method were used for all subsequent analyses. For the Mertz Glacier data this entailed scaling all counts up by $81 \%$ to account for degradation of the samples over time. This scaling factor was derived by recounting five of the samples. Initial epifluorescence counts were compared with recounts of the same samples three months later and subsequent flow cytometric estimates.

The bacterial biomass for each core section was estimated using image analysis. In addition, one-way ANOVA was used to compare the biovolume of cells present in each section of one Mertz core to determine whether biovolume fluctuated with respect to ice depth. A one-way ANOVA was also used to compare the biovolume of cells present in the bottom $100 \mathrm{~mm}$ of sea ice at each Cape Hallett sampling site. Data were log transformed prior to analysis on Systat (version 7.0).

Estimates of bacterial abundance and bacterial carbon were combined with algal counts and measurements of $\mathrm{Chl} a$ from concurrent samples and analysed using multivariate statistics to allow for correlation between response variables. All data were normalised to $\mathrm{m}^{2}$ and $\log$ transformed prior to analysis. MANOVAs were performed using the SAS (version 6.12) statistical package. An initial general linear 
model (GLM) was used to test for significant differences between sampling location, site (nested in location), core (nested in both site and location), and core section on a combined Mertz/Hallett dataset. To account for the repeat- sampling regime employed at Cape Hallett a second GLM was run on the appropriate subset of data with time added as an additional variable. Wilks' Lambda tests were conducted to protect against Type I errors prior to conducting ANOVAs on each independent variable using the statistical package R (version 2.0.1). Systat (version 8.2) was used to analyse the Cape Hallett data to test for possible differences in cell abundances between sampling sites and dates, and any interaction between site and time, using multi-way ANOVA.

Empirical curve fitting was used to detect for curvature in the distribution of cells within each sea ice profile. Both linear and quadratic models were fitted to the Mertz Glacier (20 core profiles) and Cape Hallett ( 4 core profiles) datasets with corresponding $\mathrm{p}$ values to determine best fit.

Correlations between the response variables: Bacterial abundance, bacterial carbon, algal abundance, and Chl $a$ were examined using simple linear regression. R (version 2.0.1) was used to calculate the residuals for each variable to allow for the effects of sampling site and core section on analysis. A test for zero slope was performed on all variable combinations. The Mertz and Hallett datasets were analysed separately. 


\subsection{Results}

\subsubsection{Image Analysis}

There were no significant differences between the average cell biovolume (cell size) of bacteria from the Mertz Glacier or Cape Hallett sampling locations $(F=0.0026$, df $=1, \mathrm{p}=0.956$, Table 3.1$)$. The estimate of mean cell carbon content, derived using biovolume, is also given in Table 3.1. Cell biovolume did not change in relation to depth within the ice profile of the $550 \mathrm{~mm}$ core examined from the Mertz Glacier $(\mathrm{F}=$ $1.828, \mathrm{df}=5, \mathrm{p}=0.121)$, and there was no significant difference in cell biovolume between the five sampling sites at Cape Hallett $(F=1.508, \mathrm{df}=9, \mathrm{p}=0.168)$.

The majority of bacteria visualised using epifluorescence microscopy from the Mertz Glacier were either single or dividing free-living cells with a rod-shaped morphology. The predominant cell type at Cape Hallett was of the coccoid morphology, typically occurring as single cells.

Table 3.1 Mean cell biovolume and carbon content estimated from digital images of DAPI-stained bacterial cells from the Mertz Glacier (pack ice) and Cape Hallett (fast ice).

\begin{tabular}{ccc}
\hline Location & $\begin{array}{c}\text { Mean Cell Biovolume } \\
\pm \mathbf{1 S E}\left(\boldsymbol{\mu m}^{\mathbf{3}}\right)\end{array}$ & $\begin{array}{c}\text { Mean Cell Carbon Content } \\
(\mathbf{f g})\end{array}$ \\
\hline & & 49.71 \\
Mertz Glacier & $0.35 \pm 0.032$ & 55.49 \\
\hline
\end{tabular}




\subsubsection{Bacterial enumeration: comparison of flow cytometry and epifluorescence} microscopy

The two methods of estimating bacterial abundance produced significantly different results for samples collected from the Mertz Glacier. The trend in abundance estimates indicates a weakly positive, but insignificant, correlation between flow cytometry and epifluorescence microscopy $(r=0.121, z=1.263, \mathrm{df}=110, \mathrm{p}=0.103$; Figure 3.2: A). By comparison, the samples examined from Cape Hallett exhibit a greater level of congruence with a significant positive correlation between samples processed using both methods of assessment $(r=0.597, z=1.821, d f=8, p=0.034$; Figure 3.2: B).

\subsubsection{Abundance and distribution}

The overall abundance or density of bacterial cells integrated over the whole ice thickness was not significantly different between fast ice at Cape Hallett, with an average estimate of $8.7 \pm 1.6 \times 10^{9}$ cells per $\mathrm{m}^{2}$, and pack ice of the Mertz Glacier, with an estimate of $7.6 \pm 1.2 \times 10^{9}$ cells per $\mathrm{m}^{2}(\mathrm{~F}=0.677, \mathrm{df}=1, \mathrm{p}=0.412)$.

The differences in bacterial abundance between the top and bottom of each core profile are summarised in Table 3.2. 

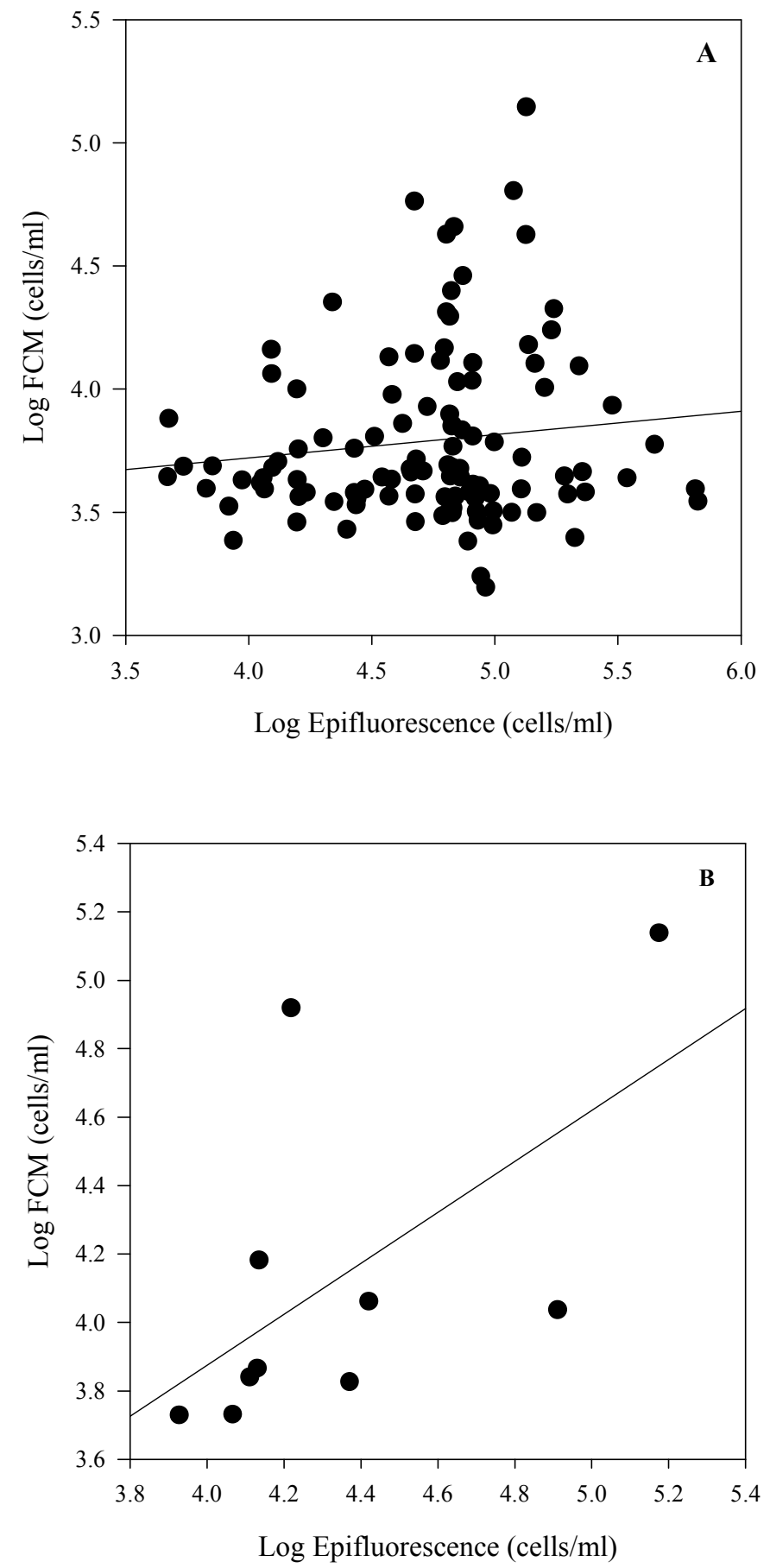

Figure 3.2 Relationship between epifluorescence and flow cytometric (FCM) enumeration of bacterial cells. Epifluorescence estimates have been obtained using DAPI staining, FCM estimates using SYBR Green II. A = Mertz Glacier, B = Cape Hallett. 
Table 3.2 Comparison of cell abundance $\left(\mathrm{m}^{2}\right)$ from the top and bottom (ice/water interface) sections of cores extracted from the Mertz Glacier $(\mathrm{n}=20)$ and Cape Hallett $(\mathrm{n}=3)$.

\section{Location Top of profile Bottom of profile}

Mean no. cells $/ \mathbf{m}^{2} \pm 1 \mathrm{SE}$ Mean no. cells $/ \mathbf{m}^{2} \pm 1 \mathrm{SE}$

\begin{tabular}{lll} 
Mertz Glacier & $1.10 \pm 0.61 \times 10^{9}$ & $1.3 \pm 0.3 \times 10^{10}$ \\
Cape Hallett & $4.1 \pm 1.7 \times 10^{9}$ & $2.60 \pm 9.3 \times 10^{7}$ \\
\hline
\end{tabular}

MANOVA results and subsequent univariate analyses are displayed in Table 3.3.

Estimates of bacterial abundance from cores extracted at the same time from each sampling site were not significantly different (Core: Site: Location, Wilk's $\lambda=0.285$, $\mathrm{df}=144,369, \mathrm{p}=0.636)$. Congruence between sites indicates the accuracy in cell estimates obtained using flow cytometry. Bacterial abundance varied significantly with depth in the sea ice at both locations (Core Section, $F=7.069, \mathrm{df}=1, \mathrm{p}=0.009$ ). This result is described in more detail in section 3.3.4.

In the second multivariate analysis, the repeat sampling at each site established at Cape Hallett provided a significant effect. An initial univariate model to test for an interaction between cell abundance and sampling site was not significant $(\mathrm{F}=0.057$, $\mathrm{df}=1, \mathrm{p}=0.814)$ and there were no significant differences between sites $(\mathrm{F}=0.264$, $\mathrm{df}=1, \mathrm{p}=0.612)$. When the change in cell abundance between the first and second survey was tested independently however (main effect), a significant increase was detected (Time $\mathrm{F}=15.572, \mathrm{df}=2, \mathrm{p}=0.0001)$. This increase is illustrated in Figure 3.3 . 
The MANOVA results in Table 3.3 also indicate variation between sampling sites when all sites from both locations are considered (Site: Location, $\mathrm{F}=2.009$, df $=11, \mathrm{p}$ $=0.031)$. As there was no variation between sampling sites at Cape Hallett, this variation must stem from the Mertz Glacier component of the data. A univariate analysis was therefore conducted on bacterial abundance for the bottom of each Mertz Glacier core profile, which showed significant differences between sites $(\mathrm{F}=3.470$, $\mathrm{df}=7, \mathrm{p}=0.0285)$, but no discernable pattern in time, latitude or ice thickness was apparent (Figure 3.4).

Table 3.3 MANOVA and ANOVA results investigating the relationship between bacterial, algal, and $\mathrm{Chl} a$ data from the Mertz Glacier and Cape Hallett. BA = Bacterial abundance; $\mathrm{BC}=$ Bacterial carbon; $\mathrm{ALG}=$ Algal abundance; $\mathrm{CHL}=$ Chlorophyll $a$; *** $\mathrm{p}<0.001 ; * * \mathrm{p}<0.01 ;{ }^{*} \mathrm{p}<0.05$; ns = not significant; na $=$ not applicable.

\begin{tabular}{|c|c|c|c|c|c|c|c|c|}
\hline \multirow[t]{2}{*}{ Location } & \multirow[t]{2}{*}{ Test } & \multicolumn{3}{|c|}{ MANOVA } & \multicolumn{3}{|c|}{ ANOVA } & \multirow[b]{2}{*}{ CHL } \\
\hline & & Wilks' $\lambda$ & $\mathrm{F}_{\mathrm{df}}$ & $\mathrm{p}$ & BA & BC & ALG & \\
\hline \multirow{4}{*}{$\begin{array}{l}\text { Mertz and } \\
\text { Hallett }\end{array}$} & Location & 0.000018 & $1309045_{4,92}$ & $* * *$ & $\mathrm{~ns}$ & ns & $* * *$ & $* * *$ \\
\hline & Core Section & 0.77 & $7.014,92$ & $* * *$ & $* *$ & $* *$ & $* * *$ & $* * *$ \\
\hline & Site: Location & 0.31 & $3.5_{36,346}$ & $* * *$ & $*$ & $*$ & $* * *$ & $* * *$ \\
\hline & Core: Site: Location & 0.28 & $0.95144,369$ & ns & ns & ns & ns & $* * *$ \\
\hline \multirow[t]{3}{*}{ Hallett only } & Site & 0.41 & $2.9616,138$ & $* * *$ & ns & & & \\
\hline & Core Section & 0.47 & $12.75_{4,45}$ & $* * *$ & na & & & \\
\hline & Time & 0.53 & $4.19_{8,90}$ & $* * *$ & $* * *$ & & & \\
\hline
\end{tabular}




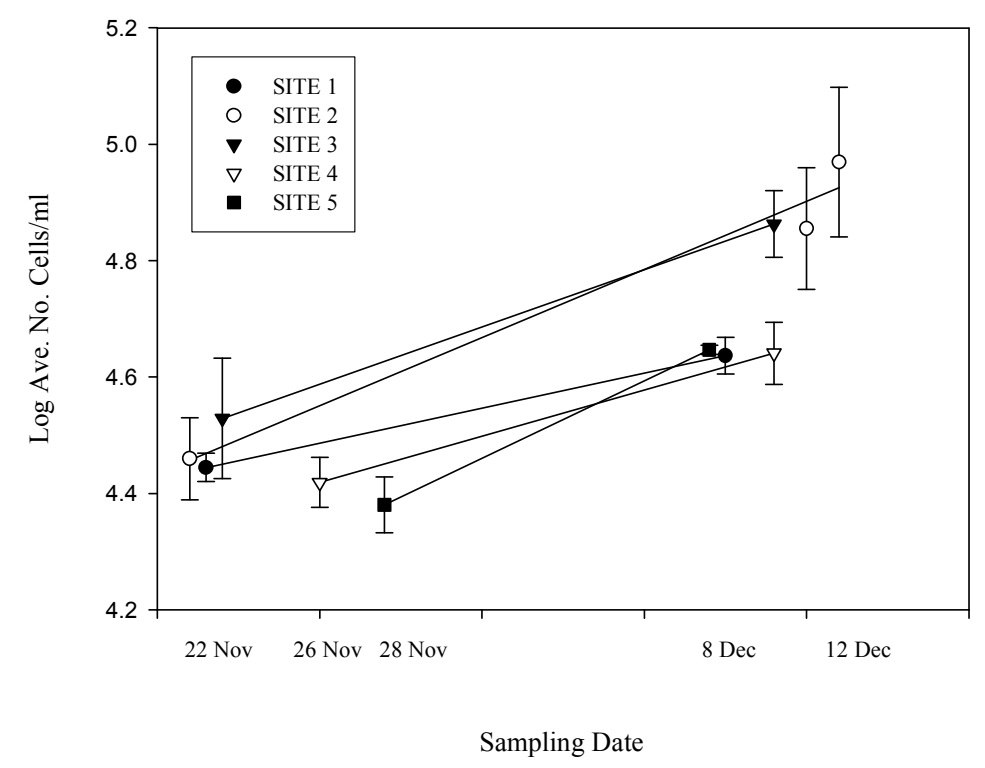

Figure 3.3 Changes in the relative abundance of bacterial cells present in the bottom $10 \mathrm{~cm}$ of fast ice from five sampling sites at Cape Hallett. Ice cores were extracted once in late November and again in early December (an additional, third sampling event, was conducted at site 2 in December).

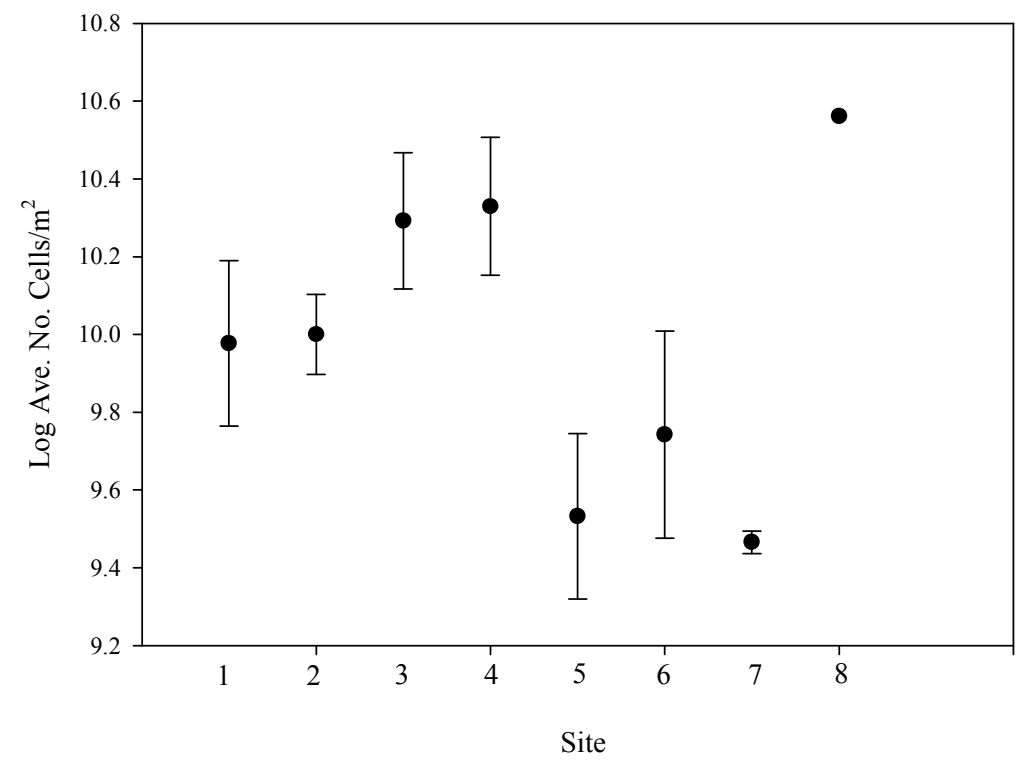

Figure 3.4 Abundance of bacterial cells present in the bottom $10 \mathrm{~cm}$ of pack ice from eight sampling sites from the Mertz Glacier. Plotted values are means \pm 1 SE. 


\subsubsection{Distribution of bacterial cells within the ice profile}

Both linear and quadratic models provided a significant fit to modelling changes in the distribution of bacterial cells with respect to position within the ice column for the Mertz Glacier (Table 3.3). The data for the combined Mertz Glacier cores is displayed in Figure 3.5 and shows that cells are most abundant in the ice/water interface region of the profile and decline towards the surface of the ice. Although there is a slight inflection in the trend of the data close to the surface, a linear correlation $(p=0.0013)$ proved to be a marginally better fit than a quadratic curve $(p=0.0019)$. It is recognised that the cores are not all of equal length in this analysis, however the cores with higher numbers of cells close to the surface were all greater than $100 \mathrm{~cm}$ in length. Four representative cores from the Mertz Glacier are also shown in Figure 3.7: A.

The core profiles extracted from Cape Hallett showed no discernible trend in the distribution of cells from the ice/water interface to the profile surface (linear, $p=$ 0.850; quadratic, $\mathrm{p}=0.136$; Table 3.3; Figure 3.6). Three cores from Cape Hallett are shown in Figure 3.7: B.

Table 3.3 Empirical curve fitting for changes in abundance of bacterial cells with respect to profile depth for the Mertz Glacier (20 core profiles) and Cape Hallett (4 core profiles). ${ }^{* * *} \mathrm{p}<0.001 ; * * \mathrm{p}<0.01 ; * \mathrm{p}<0.05$; ns $=$ not significant.

\begin{tabular}{llrl}
\hline Location & Test & t value & p \\
\hline \multirow{3}{*}{ Mertz Glacier } & & & \\
& Linear & -3.334 & $* *$ \\
& Quadratic & 3.210 & $* *$ \\
& & & \\
Cape Hallett & Linear & 0.190 & ns \\
& Quadratic & -1.514 & ns \\
\hline
\end{tabular}




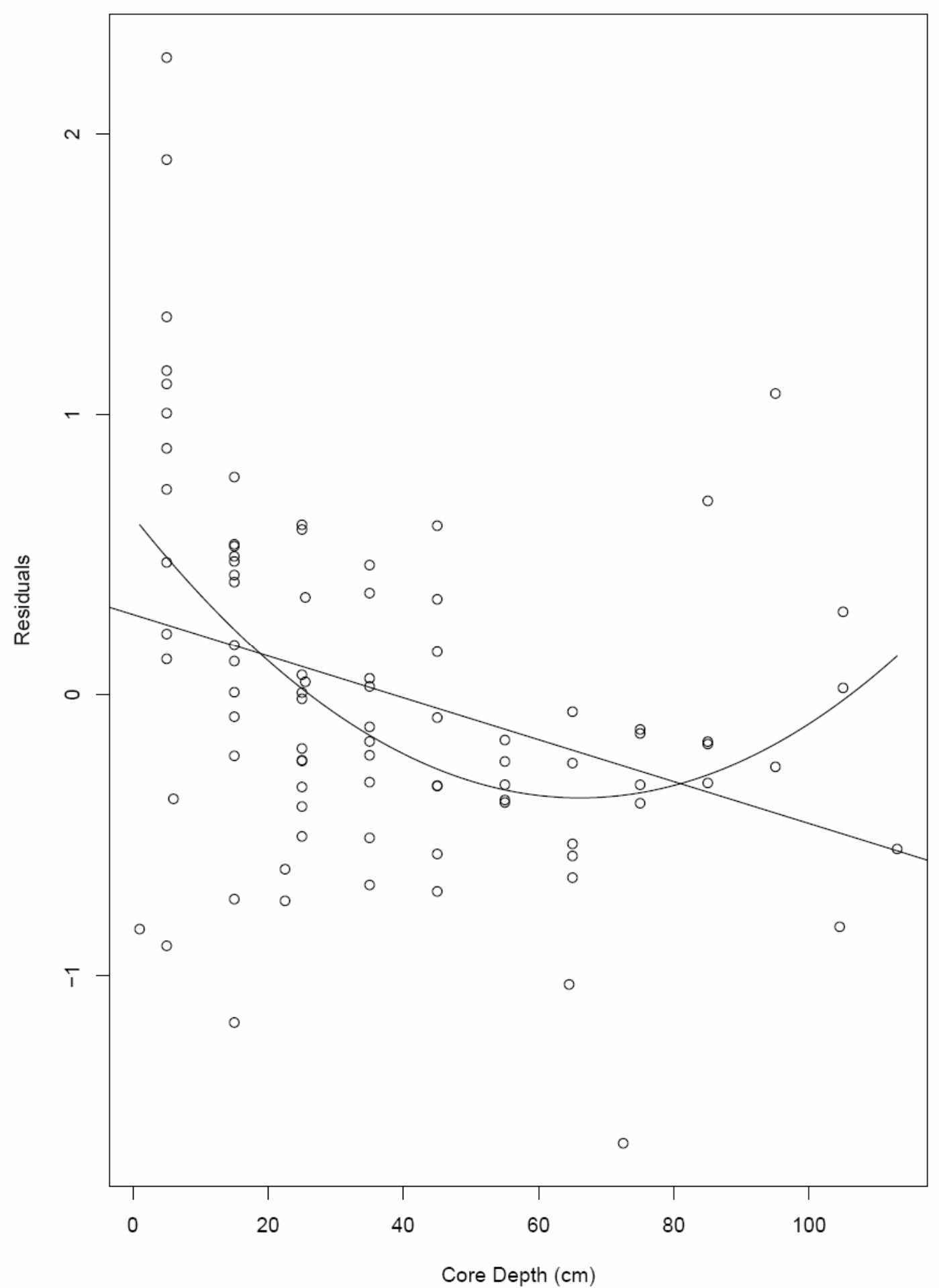

Ice/water interface

Profile surface

Figure 3.5 Bacterial abundance (log residuals) plotted against core depth for 20 pack ice profiles from the Mertz Glacier. $0 \mathrm{~cm}=$ sea/ice interface. Fitted linear and quadratic models both provide a significant fit to the data. 


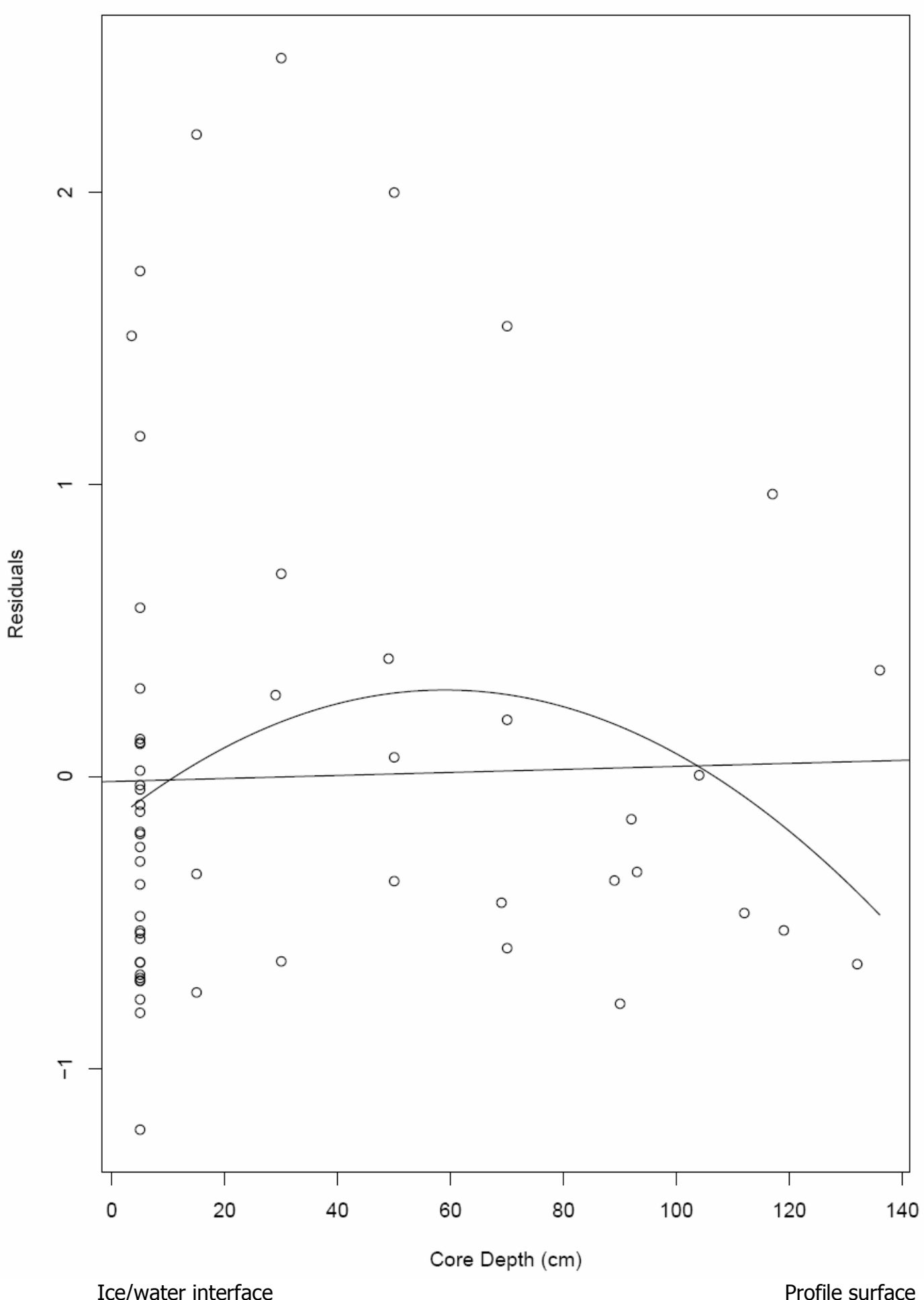

Figure 3.6 Bacterial abundance (log residuals) plotted against core depth for 4 fast ice profiles from Cape Hallett. $0 \mathrm{~cm}=$ sea/ice interface Fitted linear and quadratic models do not provide a significant fit to the data. 

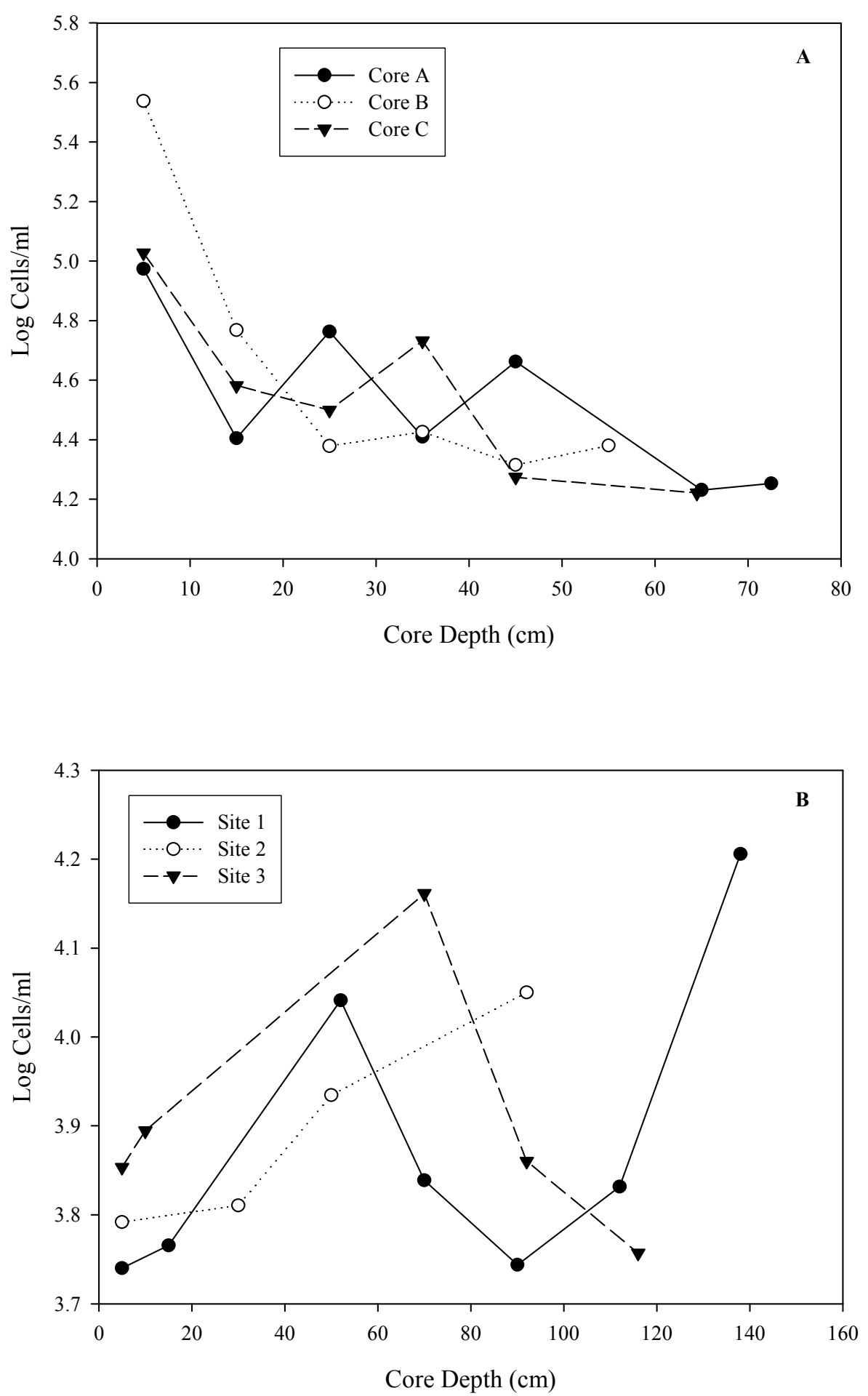

Figure 3.7 Comparison of the distribution of bacteria within ice profiles extracted from the Mertz Glacier (four representative cores displayed) (A), and Cape Hallett (cores from three sites displayed) (B). 


\subsubsection{Correlation among response variables}

Results comparing the response variables for both locations are displayed in Table

3.4. The relative abundances of bacteria and algae are positively correlated in core profiles from the Mertz Glacier $(\mathrm{r}=0.55, \mathrm{p}=<0.001)$ with a bacteria: algae cell ratio of 100:1. Estimates of bacterial carbon correlated with algal abundance (algal carbon data was not available $)(\mathrm{r}=0.286, \mathrm{p}=0.007)$, but there was no correlation between bacterial abundance and Chl $a$ at the $5 \%$ level of significance $(\mathrm{r}=0.192, \mathrm{p}=0.074)$ or bacterial carbon and Chl $a(\mathrm{r}=0.192, \mathrm{p}=0.76)$. As expected, algal abundance is positively correlated with $\mathrm{Chl} a$, and bacterial abundance with bacterial carbon.

At Cape Hallett, there was no evidence of a correlation between bacterial and algal abundance $(r=-0.144, p=0.289)$. On average, the ratio between bacteria and algae was 2.5:1. Significant, but negative, correlations were observed between bacterial abundance and Chl $a(\mathrm{r}=-0.310, \mathrm{p}=0.02)$, and likewise bacterial carbon and $\mathrm{Chl} a$ $(\mathrm{r}=-0.310, \mathrm{p}=0.019)$. Algal abundance was positively correlated with Chl $a$. 
Table 3.4 Correlation between measured variables for the Mertz Glacier and Cape Hallett sampling locations. $\mathrm{CC}=$ Correlation coefficient; $\mathrm{BA}=$ Bacterial abundance; $\mathrm{BC}=$ Bacterial carbon; $\mathrm{ALG}=$ Algal abundance; $\mathrm{CHL}=$ Chlorophyll $a$; ** $\mathrm{p}$ $<0.001 ; * * \mathrm{p}<0.01 ;{ }^{*} \mathrm{p}<0.05 ; \mathrm{ns}=$ not significant.

\begin{tabular}{llcc}
\hline Location & Test & CC & p \\
\hline \multirow{4}{*}{ Mertz Glacier } & $\mathrm{BA} \cdot \mathrm{ALG}$ & 0.286 & $* *$ \\
& $\mathrm{BA} \cdot \mathrm{CHL}$ & 0.192 & $\mathrm{~ns}$ \\
& $\mathrm{BC} \cdot \mathrm{CHL}$ & 0.192 & $\mathrm{~ns}$ \\
& $\mathrm{BC} \cdot \mathrm{ALG}$ & 0.286 & $* *$ \\
& $\mathrm{ALG} \cdot \mathrm{CHL}$ & 0.551 & $* * *$ \\
& & & \\
& $\mathrm{BA} \cdot \mathrm{BC}$ & 1.000 & $* * *$ \\
& & & \\
Cape Hallett & $\mathrm{BA} \cdot \mathrm{ALG}$ & -0.144 & $\mathrm{~ns}$ \\
& $\mathrm{BA} \cdot \mathrm{CHL}$ & -0.310 & $*$ \\
& $\mathrm{BC} \cdot \mathrm{CHL}$ & -0.310 & $*$ \\
& $\mathrm{BC} \cdot \mathrm{ALG}$ & -0.144 & $\mathrm{~ns}$ \\
& $\mathrm{ALG} \cdot \mathrm{CHL}$ & 0.561 & $* * *$ \\
& & & \\
& $\mathrm{BA} \cdot \mathrm{BC}$ & 1.000 & $* * *$ \\
\hline
\end{tabular}

\subsection{Discussion}

In this study bacterial samples from Antarctic sea ice were successfully analysed using both epifluorescence microscopy and flow cytometry. The discussion that follows focuses initially on the two methods for assessing cell numbers, then considers the differences in the distribution and abundance of bacteria at Cape Hallett and the Mertz Glacier. Coupling between bacterial growth and algal photosynthetic metabolism is then discussed as a key process in the microbial loop hypothesis. 


\subsubsection{Enumeration of bacterial cells}

Flow cytometry has become a valuable, if not essential tool, for microbial studies (Campbell, 2001; Gasol and del Giorgio, 2000; Sherr et al., 2001), and very good concordance between flow and epifluorescence estimates of bacterial concentrations has been reported (e.g. Gasol et al., 1999; del Giorgio et al., 1997; Troussellier et al., 1993; Monfort and Baleux, 1992; Robertson and Button, 1989). In this study there was very little congruence between the two methodologies in samples obtained from the Mertz Glacier (Figure 3.2 A). Possible explanations for this include non-linear loss of cells in the twelve-month storage period between the respective assessments, loss of cells in the $3 \mu \mathrm{m}$ filtration step prior to flow analysis, and possibly minor contamination of samples by the addition of sterile distilled water prior to performing epifluorescence counts.

A significant correlation was observed in the ten samples from Cape Hallett, despite the three month interval between epifluorescence counts and flow cytometry (Figure 3.2 B). It is recognised that ideally all Hallett samples would have been analysed using both methods of assessment, but it is the slow and tedious nature of filtration, slide preparation and visualisation time required for epifluorescence microscopy that has made flow cytometry such an attractive alternative (Troussellier et al., 1993). The data collected using flow cytometry were used for subsequent analyses due to both the accuracy of the method and possible contamination during epifluorescence counts. 
Storage time and use of fixatives have had a significant effect on cell concentration estimates. Although the length of storage of preserved samples prior to cell enumeration is rarely referred to in the literature, degradation of cells over time can lead to underestimates of bacterial abundance and biovolume (Turley and Hughes, 1992). Additionally, storage temperature is known to impede fluorescence-detectable cells and lead to rapid cell loss in samples stored at 4-5 ${ }^{\circ} \mathrm{C}$ (Troussellier et al., 1995; Turley and Hughes, 1994). The ethanol-preserved samples from the Mertz Glacier used in this study were kept at $4^{\circ} \mathrm{C}$ for approximately six months before epifluorescence counts were performed and a subsequent period of twelve months passed before reliable flow cytometric analysis techniques were developed.

Post-fixation cell loss and alteration of cell size has been reported with most fixatives (Gasol and del Giorgio, 2000; Lepesteur and Fleury, 1993), and some degree of cell loss due to the use of ethanol as a fixative can be assumed in samples collected from the Mertz Glacier. The loss of cells over time was modelled by Turley and Hughes (1994) to accurately calculate original cell numbers, and a similar approach was adopted in this study. While the samples collected at Cape Hallett were fixed in a manner consistent with the current literature, it was not possible to maintain samples at $-80^{\circ} \mathrm{C}$ while in a remote field camp. Results are discussed with these issues in mind. 


\subsubsection{Distribution and abundance}

Bacteria and algae were distributed vertically throughout all cores examined from the Mertz Glacier and Cape Hallett regions. While marked differences exist between the sea ice communities that develop in physically distinct ice environments (Ackley and Sullivan, 1994; Garrison, 1991), both fast ice and pack ice were found to support a comparable total bacterial biomass in this study (Table 3.2; Table 3.3). While few authors have produced estimates of bacterial abundance in either fast ice or pack ice, the data presented in this study are comparable with the findings of Kottmeier and Sullivan (1990) who found approximately $8.9 \times 10^{11}$ cells per $\mathrm{m}^{2}$ in pack ice of the Weddell Sea, Sullivan and Palmisano (1984) who reported $3.9 \times 10^{11}$ cells per $\mathrm{m}^{2}$ in fast ice in McMurdo Sound, and the figure of $1399.5 \times 10^{9}$ cells per $\mathrm{m}^{2}$ recorded by Meiners et al. (2004) in pack ice of the Bellingshausen Sea. Given the spatial and temporal variability in the sea ice environment, the average cell estimates for the Mertz Glacier $\left(7.59 \times 10^{9}\right.$ cells per $\left.\mathrm{m}^{2}\right)$ and Cape Hallett $\left(8.71 \times 10^{9}\right)$, sampled relatively early in summer, appear to be ecologically relevant.

Estimates of cell biovolume, or cell size, were found to be similar between regions (Table 3.1), which infer a degree of organismal adaptation to the different physicochemical features associated with sea ice structure. In general, bacteria found in sea ice are larger than those from the underlying seawater (Staley et al., 2002), which possibly reflects higher concentrations of dissolved organic matter in sea ice. In temperate systems, very small bacteria have been found to be dormant (inactive), while larger bacteria are more likely to be active (Gasol et al., 1995), which suggests that bacteria may readily adapt to the abiotic gradients that characterise sea ice. 
However, the observed difference in the dominant morphology of cells between regions (rods in the Mertz Glacier and cocci at Cape Hallett) may indicate that bacterial taxonomic composition differs significantly with respect to ice type or geographic region. The observation here that relatively few bacterial cells were attached to microalgae supports the findings of Grossi et al. (1984) and Sullivan and Palmisano (1984), who suggested that the $70 \%$ of the bacteria that occur in sea ice are free-living. Sullivan and Palmisano (1984) reported fluctuations in cell size with profile depth in the McMurdo Sound, with significantly larger cells present in the interstitial regions of extracted cores. The estimates of biovolume in the current study $\left(0.32-0.45 \mu \mathrm{m}^{3}\right)$ are consistent with values reported in the literature (e.g. Archer et al., 1996; Sullivan and Palmisano, 1984), and the profile examined from the Mertz Glacier revealed no significant differences in the biovolume of bacterial cells present at different depths in the profile. A similar result in comparing the biovolume of cells in the bottom region of each sampling site at Cape Hallett indicates a homogenous bacterial community and possibly a similar species composition for the area surveyed.

The distribution of bacteria within the ice column was significantly different between locations (Table 3.3). While published descriptions of the distribution of bacteria in pack ice are limited, the trend illustrated in cores extracted from the Mertz Glacier (Figure 3.5; Figure 3.7: A) mirrors that found by a number of authors (Kottmeier and Sullivan, 1990; Miller et al., 1984; Meiners et al., 2004), but not the review of work conducted in McMurdo Sound by Garrison et al. (1986). The relatively higher concentration of cells in the lower $20 \mathrm{~cm}$ of each core from the Mertz Glacier is most likely due to a layer of congelation ice, although this is more typical of fast ice habitats in sheltered coastal areas (Garrison, 1991). The presence of cells higher in 
each core profile indicates internal communities, which are thought to result from the incorporation of organisms harvested from the water column by frazil ice during the initial formation of pack ice (Garrison et al., 1986). The quadratic model fitted to the data, although marginally less significant than the linear trend, provides some evidence for a community close to the profile surface. Assemblages close to the profile surface, thought to commonly occur in pack ice, develop in a layer of infiltration ice that forms if ice floes are at some stage flooded by the surrounding seawater (Fritsen, 2001; Garrison and Buck, 1991; Garrison, 1991; Vincent, 1988).

The fast ice profiles collected from Cape Hallett are more difficult to interpret (Figure 3.6; Figure 3.7: B). The presence of cells in the lower $20 \mathrm{~cm}$ of each core indicates a layer of congelation ice that typically supports microbial communities in fast ice. Cells present at the mid point of each profile are likely to reflect the trend seen in fast ice whereby cells, following an autumnal bloom event, become trapped in the bottom congelation layer by the additional ice that forms in winter (Garrison, 1991). The lack of any discernible trend in the Cape Hallett profiles is most likely due to the presence of multiyear ice in 2003. Satellite data collected from 1979 to 2000 suggest that sea ice remains at Cape Hallett after the rest of the coast from Cape Adare to Coulman Island is clear (Falconer and Pyne, 2000). These authors also determined that the average time until ice-free water eventually appears $\left(27^{\text {th }} \mathrm{Jan}\right)$ has a standard deviation of two weeks, and while this ice-free period usually extends until early March, in some years the ice does not completely clear at all.

Bacterial production has generally been overlooked in estimates of Southern Ocean productivity (Kottmeier and Sullivan, 1990), but bacteria are known to increase in 
abundance and biomass in annual sea ice during the austral summer (e.g. Grossi et al., 1984; Kottmeier et al., 1987; Sullivan et al., 1985; Sullivan, 1985; Palmisano et al., 1986; Kottmeier and Sullivan, 1990; Kottmeier and Sullivan, 1987). Although the cores extracted from the Mertz Glacier exhibited significant site differences (Figure 3.4), there was no apparent correlation with sampling date or latitude which may have influenced bacterial abundance. A significant increase in cell abundance over time was observed at sampling sites established at Cape Hallett in 2003 indicating an active bacterial community (Figure 3.3). Although in situ bacterial production was not directly quantified during this survey, the increase in bacterial abundance clearly illustrates the ability of bacteria to grow and accumulate in the congelation layer of fast ice. This was true despite heavy ablation to the underside of the ice from a strong tidal current in Edisto Inlet and general ice degradation throughout the season. The stimulus for increased bacterial biomass is likely to be the spring diatom bloom and increased availability of algal-derived DOM, which in turn is stimulated by increased irradiance (Grossi et al., 1984).

\subsubsection{Evidence for the microbial loop}

In this study, coupling between bacteria and algae refers explicitly to a concurrent spatial relationship between bacterial and algal biomass that is likely to result, in part, from the assimilation by bacteria of algal-derived DOM. Positive relationships between bacteria and algae, or Chl $a$, have been found in sea ice at several locations in spring and summer from both the Ross Sea and Weddell Sea (Grossi et al., 1984; Kottmeier et al., 1987; Kottmeier and Sullivan, 1990; Grossmann et al., 1996; Gleitz et al., 1996) and also early winter (Stewart and Fritsen, 2004). Conversely, no 
significant relationship was found between bacteria and algae in winter sea ice by Kottmeier and Sullivan (1987) or Stewart and Fritsen (2004), which suggests that the development of a functional microbial loop is variable across seasons and habitats in Antarctica, or must be considered over an annual timeframe to account for the extended periods of absolute darkness when algal photosynthesis cannot take place, yet microbial communities continue to thrive.

In the current study, regression analysis indicates a significant positive correlation between bacterial and algal abundance for cores extracted from the Mertz Glacier (Table 3.4). This relationship provides indirect evidence that bacterial growth and microalgal photosynthetic metabolism were coupled in pack ice off the George V Coast in early summer 2002. Although it was not possible to model both the spatial and temporal dynamics of this relationship, it is likely that once coupled, bacteria continue to facilitate algal-based primary production by providing microalgae with the remineralised nutrients necessary for continued growth (Kottmeier and Sullivan, 1990). As the assimilation by bacteria of algal-derived DOM is a core process in the microbial loop hypothesis, these data provide some evidence to suggest that bacterial production may have been sufficient to support higher trophic levels or contribute to bloom events at the marginal ice zone in this region (Figure 3.8).

The lack of congruence between bacterial abundance and measurements of Chl $a$ in the Mertz Glacier data is unexpected (Table 3.4), given the reliance by various authors on measurements of Chl $a$ as an accurate surrogate for algae in modelling positive correlations with bacteria (e.g. Cota et al., 1990; Li et al., 2004b; Stewart and Fritsen, 2004). This could possibly be explained by the fact that algal cells vary substantially 
in both size and chlorophyll content, and small cells may exude proportionally more photosynthate. A greater emphasis is thus placed on direct algal counts in this study.

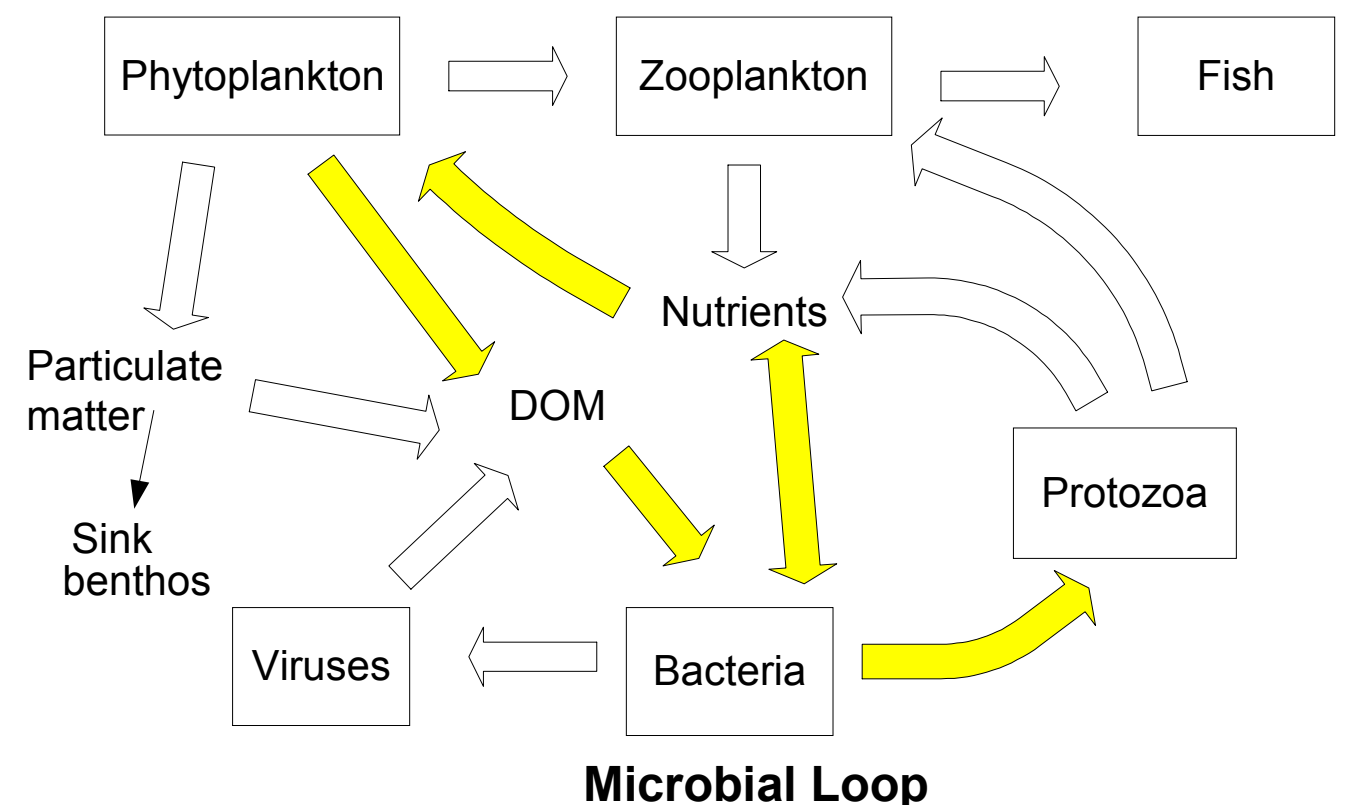

Figure 3.8 Components of the Microbial Loop.

A similar dynamic between bacteria and algae was not apparent within the fast ice microbial community at Cape Hallett in 2003. No correlation was observed between bacterial and algal abundance, which suggests that bacterial and algal production was uncoupled during the time the survey was undertaken. Although a significant result was observed in comparing bacteria with $\mathrm{Chl} a$, the trend was negative (Table 3.4). Negative relationships have been observed between algae and bacteria in sea ice west of the Antarctic Peninsula (Kottmeier and Sullivan, 1987) and also during open water surveys of the Southern Ocean (Vaqué et al., 2002; Stewart and Fritsen, 2004). 
Stewart and Fritsen suggested that an inverse relationship might develop if bacterial production lags primary production, whereby bacterial biomass may accumulate quickly while phytoplankton biomass declines. The one-month lag between phytoplankton and bacterioplankton blooms in the central Ross Sea observed by Ducklow et al. (2001) was postulated to result either from the delayed production and utilisation of algal-derived exudates or grazing by bacteria on senescent algal cells. Given the observed increase in bacterial abundance at Cape Hallett (Figure 3.4) it seems unlikely that the availability of DOM was limiting bacterial activity, particularly in the congelation layer of the profile where most measurements were taken.

An interactive effect between DOM limitation and in situ ice temperatures has been found to exert a strong control on bacterial growth and biomass (Pomeroy and Wiebe, 2001; Kottmeier and Sullivan, 1988; Helmke and Weyland, 1995), but is thought to reflect the relative age of the ice (Stewart and Fritsen, 2004). Bacterial assemblages in new ice can be dominated by species from the water column that are not adapted for growth within the ice matrix, but as the ice ages, the relative proportion of psychrophilic bacteria (capable of growth at or below $0^{\circ} \mathrm{C}$ ) increases as cold-adapted strains are selected (Grossmann and Gleitz, 1993; Helmke and Weyland, 1995).

Due to the presence of multiyear ice at Cape Hallett in 2003, it is likely that bacteria present in the mid regions of the core profiles were well adapted to ambient temperatures and saline conditions. The apparent discrepancy between primary and secondary production in this region of the profile may reflect the characteristics of multiyear ice and an 'old' biota with respect to algal metabolism and supply of DOM. 
Although significant increases in the abundance of bacterial cells present in essentially the newest (congelation) layer of ice at each site was observed, it seems bacterial production may have, at least temporarily, lagged behind algal production during early summer. This is indicated by the considerably reduced bacteria: algae ratio. While it was beyond the scope of this study to quantify the trophodynamics associated with the microbial loop hypothesis, metabolic uncoupling may limit the seasonal availability of both bacterial and algal productivity to consumers within the sea ice. The extent to which uncoupling of the microbial loop impacts coastal marine processes is unknown, but highlights the need to quantify the fate of bacterial productivity in Antarctic coastal ecosystems for both fast ice and pack ice environments.

The findings of this study indicate that the spatial and temporal nature of Antarctic sea ice requires observation of the seasonal development of biomass and production to validate trophodynamics and Southern Ocean carbon cycling (e.g. Delille et al., 1995; Archer et al., 1996; Ducklow et al. 2004; Stewart and Fristen, 2004).

It is recognised that the data presented in the current study provide a 'snapshot' of the microbial dynamics, particularly with respect to sampling at the Mertz Glacier. However, the sampling methodology has been sufficient to illustrate the variability in community structure and dynamics between fast ice and pack ice in two geographically related areas of Antarctica. This data contributes to the limited research conducted to date on sea ice bacteria, particularly with respect to the pack ice environment. Under the auspices of the Latitudinal Gradient Project, this study is the first to investigate sea ice bacteria in the Cape Hallett region and will contribute to an understanding of the ecosystems that exist along the Victoria Land coastline. 


\title{
Chapter 4: Metabolic assessment of Antarctic sea ice bacteria
}

\begin{abstract}
Sea ice is a predominant feature of polar oceans and exerts a unique influence on the Southern Ocean marine ecosystem. Productivity in the water column is significantly limited by the presence of sea ice and maintained primarily by those algae and bacteria that form distinct assemblages within the ice profile. Projected warming for polar regions over the $21^{\text {st }}$ century is likely to reduce the extent and volume of annual sea ice, which will alter both the light and saline regimes to which the microbial community is exposed. Understanding the bacterial response to environmental change in the sea ice ecosystem may provide an insight into the potential long-term changes to the physical oceanography and ecology of the Southern Ocean. The metabolic response of bacterial assemblages to experimentally induced changes in light and salinity was assessed using the tetrazolium salt 5-cyano-2,3-ditolyl tetrazolium chloride (CTC) in fast ice at Cape Hallett, Antarctica. Two distinct communities within the ice were investigated, the brine channel assemblage and the interstitial or bottom assemblage. This study presents preliminary evidence that the metabolic activity of brine bacteria is influenced by light stimulus. The near linear positive increase of cell activity with increasing incubation irradiance is likely to be an indirect response to the availability of dissolved organic matter, but may also indicate the presence of photosynthetic bacterial species. Additional results indicate that saline concentration is more significant than light irradiance in influencing the metabolic response of cells present in the interstitial region of the sea ice profile. As a vital metabolic stain, CTC appears to be applicable to Antarctic field conditions, and may prove to be useful in quantifying the role of bacteria in Antarctic sea ice.
\end{abstract}




\subsection{Introduction}

While the causal mechanisms and implications remain controversial, it has become widely recognised that human generated emissions have altered the global climate system (Joos et al., 2001). Atmospheric carbon concentrations are projected to reach between 540 and $970 \mathrm{ppm}$ by 2100 and average global surface temperatures to increase by 1.4 to $5.8^{\circ} \mathrm{C}$ (Joos et al., 2001). Of all the responses to future climatic warming, changes to Antarctic sea ice are expected to be among the most notable (Budd, 1991). Although few data are currently available to asses the effects of climate change on sea ice dynamics and microbial production within the Antarctic coastal ecosystem, changes in the magnitude and timing of seasonal sea ice advance and retreat are likely to have significant ecological consequences (Smith et al., 1998). Climate models currently predict a reduction in the volume of Antarctic sea ice by 25$45 \%$ in the next century (Gordon and O'Farrell, 1997), and a corresponding reduction in mean sea ice extent of nearly two degrees of latitude (Wu et al., 1997). If atmospheric warming is sustained, there are likely to be long-term changes to the physical oceanography and ecology of the Southern Ocean (White et al., 2001).

Productivity in the Southern Ocean is characterised by large-scale spatial and temporal variability as sea ice influences not only the pelagic systems under the ice, but also determines the ecology of the biota within the ice (Ackley and Sullivan, 1994; Legendre et al., 1992; Delille, 1992). Efforts to investigate the sea ice microbial community have focused primarily on understanding the composition and physiology of the photosynthetic algae that dominate fast ice assemblages (e.g. Garrison, 1986; Ryan and Beaglehole, 1994; Thomas et al., 2001; Trenerry et al., 2002; Ryan et al., 2004; Kühl, 2001). When the ice melts each year this algal biomass can contribute up 
to $30 \%$ of the total annual primary production of the ice-covered Southern Ocean (Arrigo et al., 1997).

Bacteria, protozoa, fungi, and invertebrates have been described in sea ice, in addition to algae (Garrison, 1986; Vincent 1988; Garrison, 1991; Staley and Gosink, 1999; Staley et al., 2002). As recently as 1968, however, bacteria were considered to be extremely low in abundance or even nonexistent in polar seas (Sorokin, 1971 cited in Sullivan, 1985). A diverse bacterial community has now been described from annual fast ice that exhibits similar patterns of biomass, production and growth rates to that of phytoplankton (Cota et al., 1990). There is however, no consensus with respect to the importance of bacterial secondary production to overall trophodynamics (Ducklow et al., 1999; White et al., 1991). The proposed microbial loop has emphasised several important links to higher trophic levels, particularly through the utilisation of dissolved organic matter (DOM) (Sullivan and Palmisano, 1984; Azam et al., 1991), but direct evidence for the functioning of this microbial loop remains limited. Several authors have found a positive relationship between bacterial and algal biomass/production in sea ice during spring/summer (Grossi et al., 1984; Kottmeier et al., 1987; Kottmeier and Sullivan, 1990; Stewart and Fritsen, 2004); conversely Kottmeier and Sullivan (1987) found no significant relationship between algae and bacteria in late winter sea ice. Bacterial assimilation of DOM is a core process in the microbial loop hypothesis yet remains equivocal with respect to spatial and temporal sea ice dynamics (Stewart and Fritsen, 2004). 
There is considerable evidence that a significant fraction of pelagic bacteria are either dead, or relatively inactive (Howard-Jones et al., 2001; Cole, 1999; Sherr et al., 1999a,b). This realisation has led to the development of a number of techniques capable of assessing the activity of individual cells. These vital stains and probes target a number of properties associated with cellular physiology such as membrane integrity, specific enzyme activity, ribosomal RNA content, and cellular reducing potential (Howard-Jones et al., 2001).

The probe that has been most widely used to asses single cell activity is 5-cyano-2,3ditolyl tetrazolium chloride (CTC) developed by Rodriguez et al. (1992). CTC is a colourless, membrane permeable compound that is readily reduced via the electron transport system (ETS) of bacterial cells to produce a red-fluorescing insoluble CTCformazan that accumulates within the cell (Smith and del Giorgio, 2003). This technique has gained wide application in recent years in environmental studies and has been reported by various authors to be a simple and effective method of counting active bacteria, without the need for sophisticated equipment (Créach et al., 2003).

The use of CTC however, remains controversial. Cells that reduce sufficient CTC to be scored as ETS-active are considered to be alive and capable of growth (Choi et al., 1999). Ullrich et al. (1996) have claimed that the stain in fact inhibits metabolism in bacterial cells and underestimates the proportion of active cells in natural aquatic environments. Several other authors suggest that bacteria should be defined by a continuum of metabolic states rather than simply 'active' or 'inactive' (Gasol and del Giorgio, 2000; Sieracki et al., 1999). In addition, it is not certain whether all bacterial strains are capable of reducing this compound to its fluorescent form (Choi et al., 
1999; Bernas and Dobrucki, 2000). Although some fraction of active cells may be misrepresented by the CTC assay, there is general agreement that this technique may be used to determine the most active cells in a natural population (Sieracki et al., 2003; del Giorgio and Bouvier, 2002; Sherr et al., 2001; Sherr et al., 1999a; del Giorgio et al., 1997).

This study describes the first application of CTC in Antarctic field conditions. In addition, the efficacy of the assay to provide ecologically meaningful results is determined and the response of bacterial cells to changes in light and salinity is examined. The gradients in light and salinity that characterise the sea ice environment are likely to change dramatically in coming decades if there is any reduction in the extent and volume of annual sea ice. Understanding the potential stress response of the various microbial assemblages to a changing climate has implications not only for sea ice trophodynamics but also Southern Ocean productivity. In this paper, two questions are addressed:

(1) What is the metabolic response of bacteria present in the brine channel assemblage to light?

(2) What is the metabolic response of bacteria from the interstitial or bottom assemblage to experimental changes in both light and salinity?

The response of sea ice algae was also assessed in a parallel study (Ryan et al., in prep; Ralph et al., in prep.). 


\subsection{Methods}

\subsubsection{Sample Collection}

\section{Brine community}

Algae and bacteria were collected in November 2003 from fast ice approximately $1.5 \mathrm{~m}$ thick at Cape Hallett, Antarctica (Figure 4.1). A series of shallow holes $(<0.5 \mathrm{~m})$ were drilled in close proximity with a powered ice auger (Jiffey) and immediately cleared of ice shavings. Each hole was covered with an opaque sheet and left for approximately 10 minutes to allow the brine and associated microbes to drain from the severed channels within the ice. The accumulated brine was then carefully removed from each hole (under the cover of an opaque sheet), passed through a coarse filter to remove any ice shavings and collected in an opaque jerry can. The algae and bacteria present in this filtrate were concentrated under low light $\left(<1 \mu \mathrm{mol}\right.$ photons $\mathrm{m}^{-}$ ${ }^{2} \mathrm{~s}^{-1}$ ) using a $47 \mathrm{~mm}$ Millipore filtering apparatus and a series of $0.22 \mu \mathrm{m}$ filter membranes. The cells collected on each membrane were carefully removed and returned to filtered brine $(0.22 \mu \mathrm{m})$ with a salinity of approximately $70 \mathrm{ppt}$. This provided a $360 \mathrm{ml}$ solution of concentrated algae and bacteria that was kept dark in a cold box prior to incubation.

\section{Bottom Community}

A SIPRE corer was used to extract 10 cores $(130 \mathrm{~mm}$ in diameter and $200 \mathrm{~mm}$ in length) from sea ice at Cape Hallett in December 2003. An opaque sheet was employed to prevent cell exposure to ambient surface radiation during core removal. Once extracted, each core was transferred to a black polythene bag. Under low light 
conditions $\left(<1 \mu \mathrm{mol}\right.$ photons $\left.\mathrm{m}^{-2} \mathrm{~s}^{-1}\right)$, the bottom 5-10mm of ice was cut from each core, weighed and melted in three times the respective volume of filtered seawater $(0.22 \mu \mathrm{m}, 36 \mathrm{ppt})$ over a period of $12 \mathrm{hrs}$. Samples were then combined and concentrated using the method described earlier. Collected cells were retained in approximately $500 \mathrm{ml}$ of melted seawater with a saline concentration of $33.6 \mathrm{ppt}$.

To produce a range of saline treatments, brine (approx. 72ppt) was collected from a series of auger-drilled holes and filtered to $0.22 \mu \mathrm{m}$ to remove all cells.

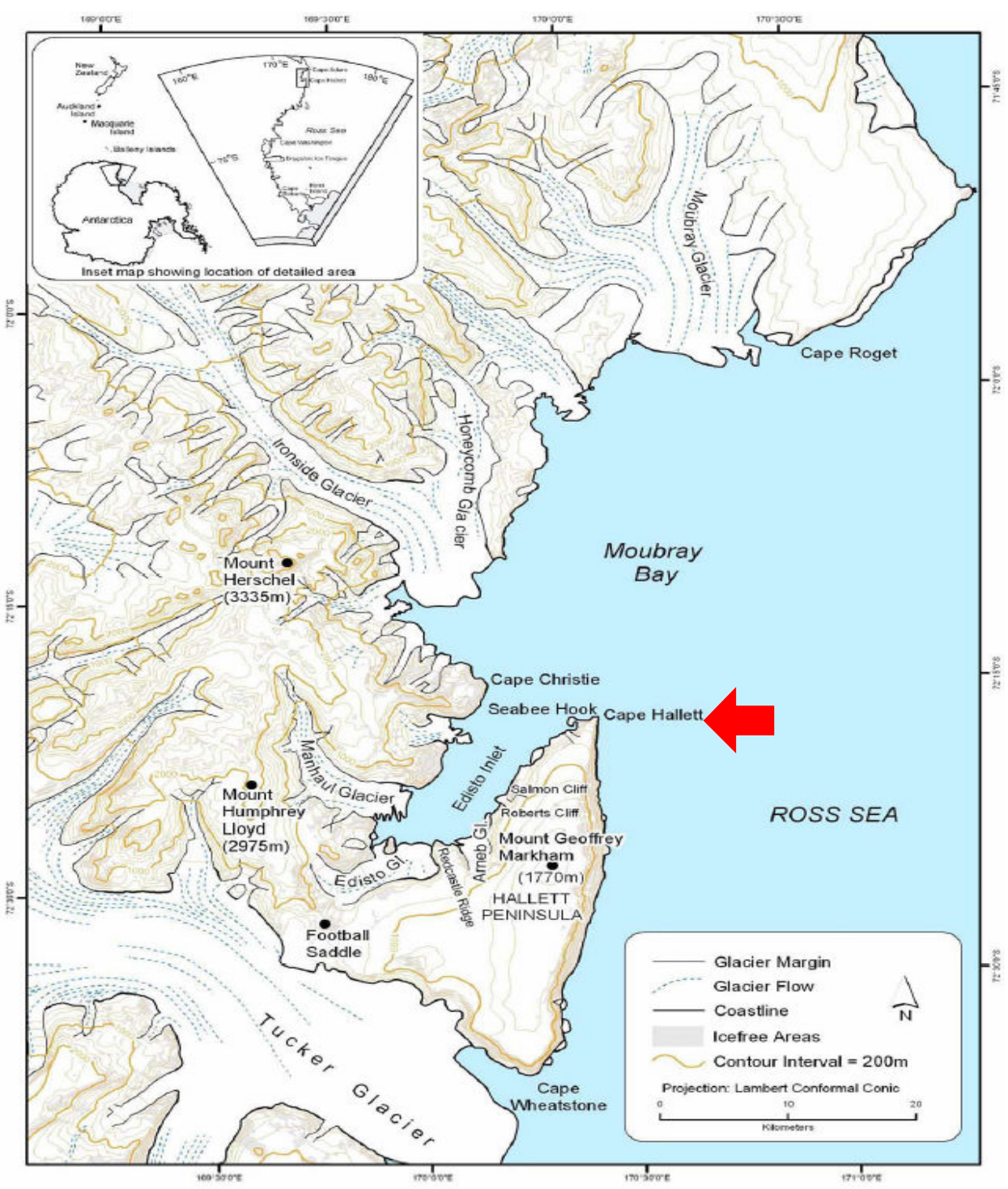

Figure 4.1. Map showing location of Cape Hallett, Antarctica (Gordon, 2003). 


\subsubsection{Experimental Protocol}

\section{Effect of light on the brine community}

To determine the brine community response to incubation irradiance twenty-four 15 $\mathrm{ml}$ samples of the concentrated solution were placed in centrifuge tubes and incubated in a water bath for 4 hours at $-0.7^{\circ} \mathrm{C}$. An ethanol: water $(1: 4)$ mixture with a $10 \mathrm{~m}$ copper heat exchanger buried in ice was used to provide sub-zero temperatures and a heater stirrer was used to maintain the incubator temperature to within $\pm 0.1^{\circ} \mathrm{C}$. Samples were arranged randomly within the incubator and exposed to a level of overhead light of either: $4.6,18.5,37,75$, or $150 \mu \mathrm{mol}$ photons $\mathrm{m}^{-2} \mathrm{~s}^{-1}$. An additional dark treatment was also included. Therefore there were five light treatments, one dark treatment and four replicates of each treatment $(n=24$ samples $)$. After four hours samples were removed and centrifuged at ca. $2000 \mathrm{~g}$ for 5 minutes for the fast kinetic measurements of algal cells using a plant efficiency analyser (PEA) fluorometer. Samples were then resuspended and incubated for a further 20 minutes before removal for the generation of rapid light curves on algal cells using a pulse amplitude modulated (PAM) fluorometer (See Ryan et al. in prep).

$900 \mu 1$ of each sample was then transferred from each centrifuge tube and placed in separate $1 \mathrm{ml}$ Eppendorf tubes. $100 \mu 1$ of CTC (Polysciences) was added to each tube (5mM final concentration) before being returned to the same position within the water bath, and incubated for a further four hours under the same light conditions. Cells were then fixed by the addition of $0.22 \mu \mathrm{m}$-filtered formalin ( $5 \%$ final concentration), 
kept as cold as possible and stored in the dark. During the next 48 hours each sample was counterstained with DAPI $\left(5 \mu \mathrm{g} \mathrm{ml}^{-1}\right)$ and incubated for 10 minutes in the dark before being vacuum filtered onto a white Millipore $0.22 \mu \mathrm{m}$ cellulose filter membrane.

Tweezers were used to carefully mount each membrane onto a slide before a drop of Vectashield mounting medium (Vector Laboratories) was added. Cover slips were sealed with nail polish. Each slide was inspected immediately via epifluorescence microscopy using a Zeiss microscope under oil immersion at 1000x magnification. For each slide, 4-5 fields of view were randomly chosen to perform cell counts. Bacterial cells stained with DAPI were identified using a UV filter set to estimate the total number of bacterial cells, and then a blue light filter set was used to determine the number of cells that had accumulated reduced CTC in the same field of view. The percentage of metabolically active cells present on each slide was then calculated.

\section{Effect of light and salinity on the bottom community}

For the bottom community experiment the concentrated cell solution was divided into ten $50 \mathrm{ml}$ volumes. In order to prevent osmotic shock, each culture was brought to the desired salinity over a period of eight hours with the timed addition of either brine or filtered seawater. The experiment was run in two parts: part A $(n=30)$ and part B $(n=30)$. The final salinity treatments after eight hours of acclimation (including minor differences between part A and B) are shown in Table 4.1. 
Table 4.1 Final salinity readings of bottom community experiment after eight-hour period of acclimation.

Salinity: Part A: Part B:

$\begin{array}{lll}\text { S1 } & 15.4 & 16.0 \\ \text { S2 } & 21.7 & 21.2 \\ \text { S3 } & 34.4 & 34.4 \\ \text { S4 } & 51.2 & 52.2 \\ \text { S5 } & 64.0 & 64.0\end{array}$

Prior to incubation two $900 \mu 1$ sub-samples of each salinity treatment (1-5), both A and B $(n=20)$ were placed in separate Eppendorf tubes to provide an experimental control. The sample in each Eppendorf tube was stained with CTC (5mM final concentration), incubated in the dark for four hours and subsequently fixed with $0.22 \mu \mathrm{m}$-filtered formalin.

Following an eight hour period of dark acclimation to the new salinity, two $15 \mathrm{ml}$ subsamples of each saline treatment for part A were placed in centrifuge tubes and incubated in a water bath at a temperature of $-0.7^{\circ} \mathrm{C}$. Samples were arranged randomly within the incubator and exposed to either 0,37 or $150 \mu \mathrm{mol}$ photons $\mathrm{m}^{-2} \mathrm{~s}^{-1}$ for a period of four hours. There were five salinity treatments, three light treatments and two replicates of each treatment $(n=30$ samples). Following this period, each sample was centrifuged and resuspended as per the protocol described in the first experiment. For bacterial assessment, $900 \mu 1$ was removed from each centrifuge tube, stained with CTC (5nM final concentration) and returned to the appropriate position in the incubator for a further four hours. At the end of this interval, cells were fixed 
with $0.22 \mu \mathrm{m}$-filtered formalin ( $5 \%$ final concentration) and stored in the dark. This process was then repeated for part B of the experiment ( 5 salinity levels, 3 light levels, two replicates $=30$ samples), which was timed such that incubation followed an equal eight-hour period of acclimation.

Prior to counterstaining, $200 \mu 1$ was removed from each sample and transferred to a separate Eppendorf tube containing $800 \mu 1$ of $0.22 \mu \mathrm{m}$-filtered seawater. This was done to reduce the number of cells to be subsequently counted. Samples were prepared as slides and bacteria visualised using epifluorescence microscopy to determine total and $\mathrm{CTC}+$ cells as previously described in the brine experiment.

In addition to the pre-incubation controls, six centrifuge tubes were randomly selected from part A and B, and on return to Victoria University of Wellington inspected for the presence of autofluorescent cells using both blue light and UV filter sets. To determine the influence of incubating under a light regime, CTC was added to six $900 \mu 1$ samples of $0.22 \mu \mathrm{m}$-filtered double distilled water. Three samples were incubated in the dark and three samples were incubated under $150 \mu \mathrm{mol}$ photons $\mathrm{m}^{-2} \mathrm{~s}^{-}$

${ }^{1}$ for four hours. Each sample was examined for the presence of reduced CTC.

\subsubsection{Statistical Analyses}

Data analysis was performed using SYSTAT 8.0. In the brine experiment a logit link regression model was used to determine the effect of light on cell metabolic activity. Following a log transformation of the data, a post hoc Tukey test was performed to determine all possible pairwise comparisons of light treatments. 
The logit link regression technique was also used to determine the effects of light and salinity in the bottom community experiment. Grubb's test was initially used to identify a spurious data point in the pre-incubation data set and this was subsequently removed before conducting a post hoc Tukey test to compare saline treatments. A series of regression models were fitted to the incubation data. Parts A and B were initially combined for analysis, and then analysed separately as a batch effect was detected in the combined model.

\subsection{RESULTS}

\subsubsection{Effect of light on the brine community}

The percentage of bacterial cells deemed metabolically active varied from 0 to $45 \%$. This observed variation in the level of activity was strongly correlated with the level of light irradiance $\left(\chi^{2}=3004, \mathrm{df}=1, \mathrm{p}<0.0005\right)$. The increase in irradiance and corresponding level of cell activity follows a near linear positive correlation (Figure 4.2). No metabolic activity was detected in those cells incubated in the dark.

The results of the post hoc Tukey test comparing treatment means is displayed in Table 4.2. No significant difference in the number of active cells is detected in comparing the first four treatment means $\left(0,6.25,18.5\right.$ and $37 \mu \mathrm{mol}$ photons $\left.\mathrm{m}^{-2} \mathrm{~s}^{-1}\right)$, as indicated by a common underline $(\alpha=5 \%)$. The increase in incubation irradiance from 37 to $75 \mu \mathrm{mol}$ photons $\mathrm{m}^{-2} \mathrm{~s}^{-1}$ resulted in a statistically significant increase in the average number of active cells when compared with the lower levels of irradiance. The average number of active cells incubated at $150 \mu \mathrm{mol}$ photons $\mathrm{m}^{-2} \mathrm{~s}^{-1}$ is significantly greater than all other light levels. 


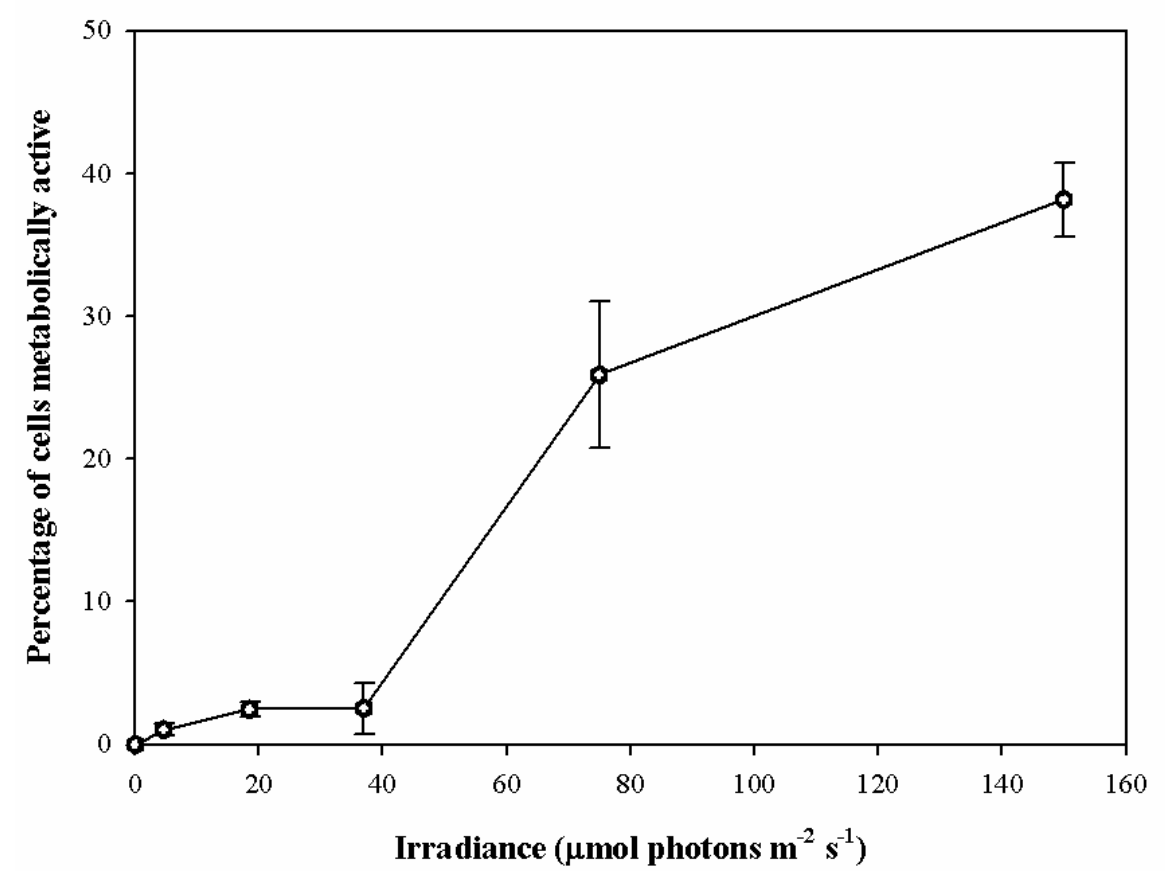

Figure 4.2 Influence of light irradiance on percentage of metabolically active bacterial cells from sea ice brine. Plotted values are means $\pm 1 \mathrm{SE}$.

Table 4.2 Post hoc Tukey test of treatment means. Common underline indicates no significant difference between means $(\alpha=5 \%)$

$\begin{array}{lllllll}\text { Light Level: } & \mathbf{0} & \mathbf{6 . 2 5} & \mathbf{1 8 . 5} & \mathbf{3 7} & \mathbf{7 5} & \mathbf{1 5 0} \\ \text { Mean: } & 0 & 1.03 & 2.45 & 2.51 & 25.92 & 38.19\end{array}$




\subsubsection{Effect of light and salinity on the bottom community}

In the control group no reduced CTC was observed under blue light excitation in either the dark or light- incubated $\left(150 \mu \mathrm{mol}\right.$ photons $\left.\mathrm{m}^{-2} \mathrm{~s}^{-1}\right)$ samples of filtered water following a four-hour incubation period. No autofluorescent cells or debris were observed under either UV or blue light excitation in the six randomly selected samples from part $\mathrm{A}$ and $\mathrm{B}$.

\section{Pre-incubation}

Metabolically active cells were observed in all five saline treatments following the eight-hour period of acclimation (Figure 4.3). With the removal of one treatment replicate from salinity 1 ( $15.7 \mathrm{ppt}$ ) (Grubb's test for significant outliers), the percentage of metabolically active cells showed a significant response to salinity $\left(\chi^{2}=\right.$ 15.27, $\mathrm{df}=1, \mathrm{p}=0.0001)$.

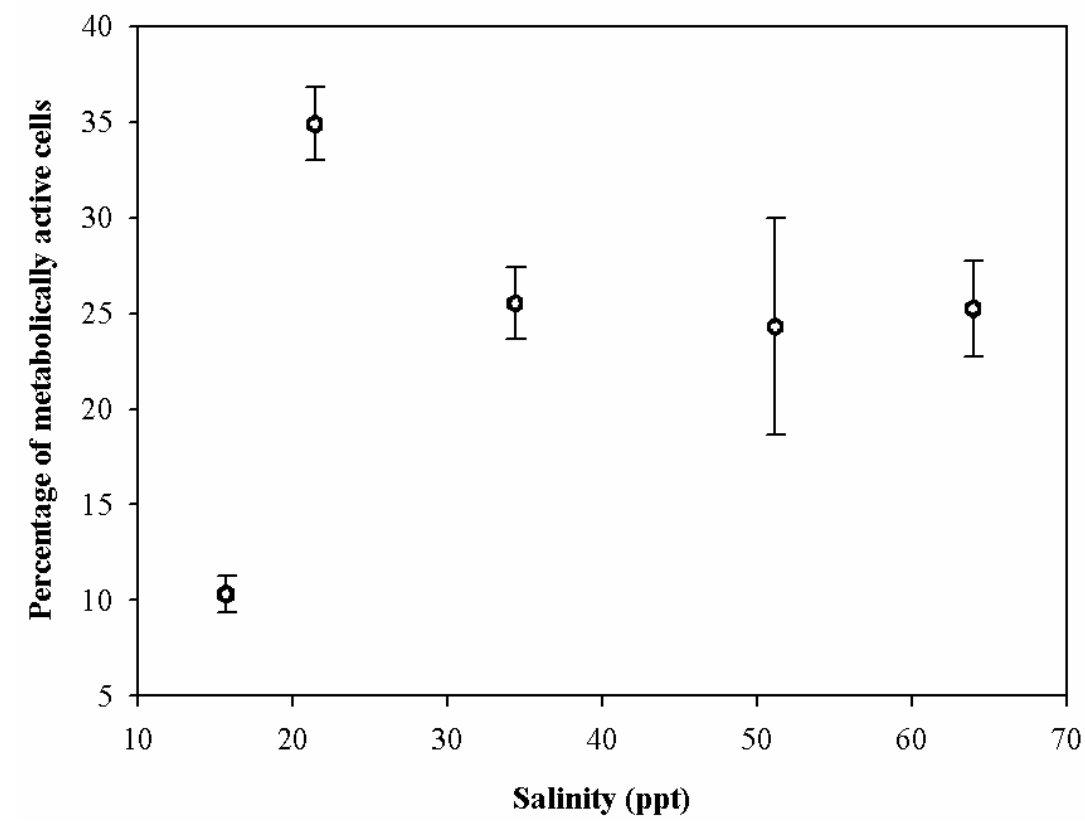

Figure 4.3 Percentage of metabolically active bacterial cells acclimated to a range of salinities. Plotted values are means \pm 1 SE. Note: For salinity $1(15.7 p p t) n=2$, one missing value, one value removed; for salinities $2,3,4,5 n=4$. 
Variation in metabolic activity of cells incubated at saline concentrations of 21.5 ,

$34.4,51.7$, and $64.0 \mathrm{ppt}$ is not statistically significant $(\alpha=5 \%)$, however the post hoc

Tukey test indicates reduction in bacterial metabolic activity in cells incubated at 15.7ppt (Table 4.3).

Table 4.3 Post hoc Tukey test of treatment means. Common underline indicates no significant difference between means $(\alpha=5 \%)$

Salinity:

Mean:
(2)

21.5

34.91
(3)

34.4

25.54
(4)

51.7

24.31
(5)

64.0

25.26

\section{Incubation}

Bacterial metabolic activity was detected at each level of irradiance and in each saline regime following the eight-hour period of incubation. Estimates of metabolically active cells ranged from $0-65 \%$. The initial logit regression model fitted to the combined data set (both part A and B) indicated significant effects of light $\left(\chi^{2}=\right.$ 1279.47, $\mathrm{df}=3, \mathrm{p}=0.0001)$ and the batch $\left(\chi^{2}=1279.47, \mathrm{df}=3, \mathrm{p}<0.0001\right)$. The proportion of cells observed to be metabolically active was similar regardless of saline concentration $\left(\chi^{2}=1279.47, \mathrm{df}=3, \mathrm{p}=0.7400\right)$.

A logit regression model fitted only to part A of the dataset indicates both light $\left(\mathrm{x}^{2}=\right.$ 139.6013, $\mathrm{df}=2, \mathrm{p}<0.0005)$ and salinity $\left(\mathrm{x}^{2}=139.6013, \mathrm{df}=2, \mathrm{p}<0.0005\right)$ to be significant in influencing metabolic activity. 
For cells maintained under zero light conditions, the number of cells deemed metabolically active following eight hours of incubation is significantly less than the pre-incubation control group $(\mathrm{t}=4.0859, \mathrm{df}=16, \mathrm{p}=0.0009)($ Figure 4.3:A; Figure 4.4:A). No trend in the response to salinity is apparent under zero light for part A. Cells exposed to irradiances of 37 and $150 \mu \mathrm{mol}$ photons $\mathrm{m}^{-2} \mathrm{~s}^{-1}$ show a marked decline in metabolic activity with increasing salinity (Figure 4.3: B, and C).

In contrast to part $\mathrm{A}$, a regression analysis of the part $\mathrm{B}$ dataset indicates no effect of light $\left(\chi^{2}=36.89, \mathrm{df}=2, \mathrm{p}=0.1259\right)$, while salinity remains a significant influence on activity $\left(\chi^{2}=36.89, \mathrm{df}=2, \mathrm{p}<0.0005\right)$. For incubations conducted under zero light and at $37 \mu \mathrm{mol}$ photons $\mathrm{m}^{-2} \mathrm{~s}^{-1}$ a very minor trend in the data is apparent with fewer active bacterial cells at either salinity extreme (16.0 and 64.0ppt respectively)(Figure 4.4: A, and B). This pattern is not mirrored in cells incubated at $150 \mu \mathrm{mol}$ photons $\mathrm{m}^{-2}$ $\mathrm{S}^{-1}$ 


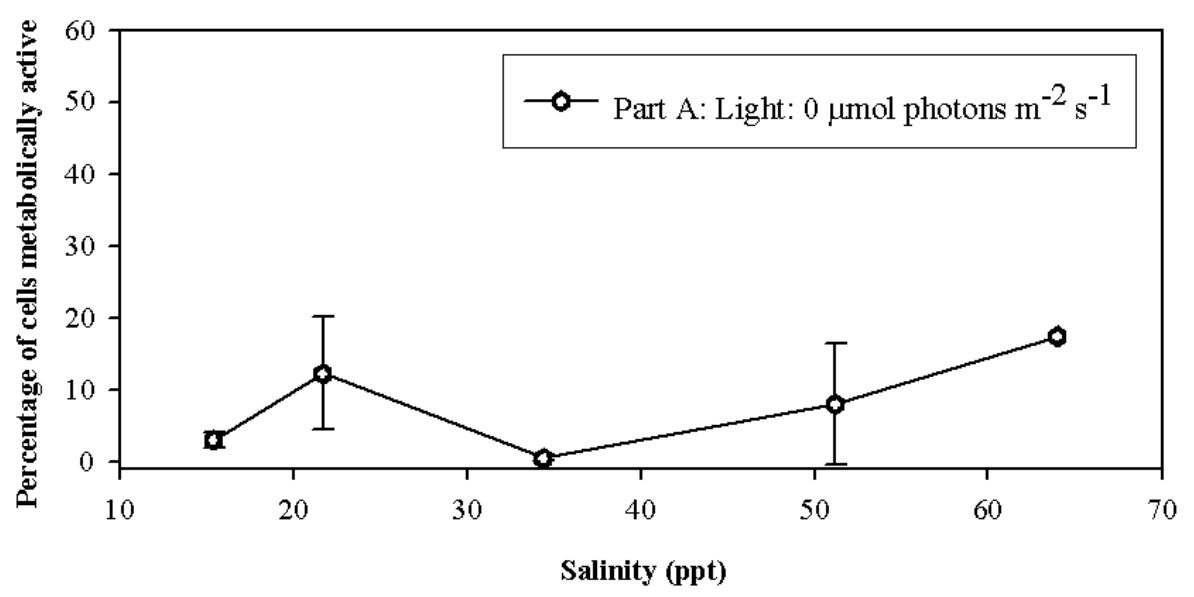

A

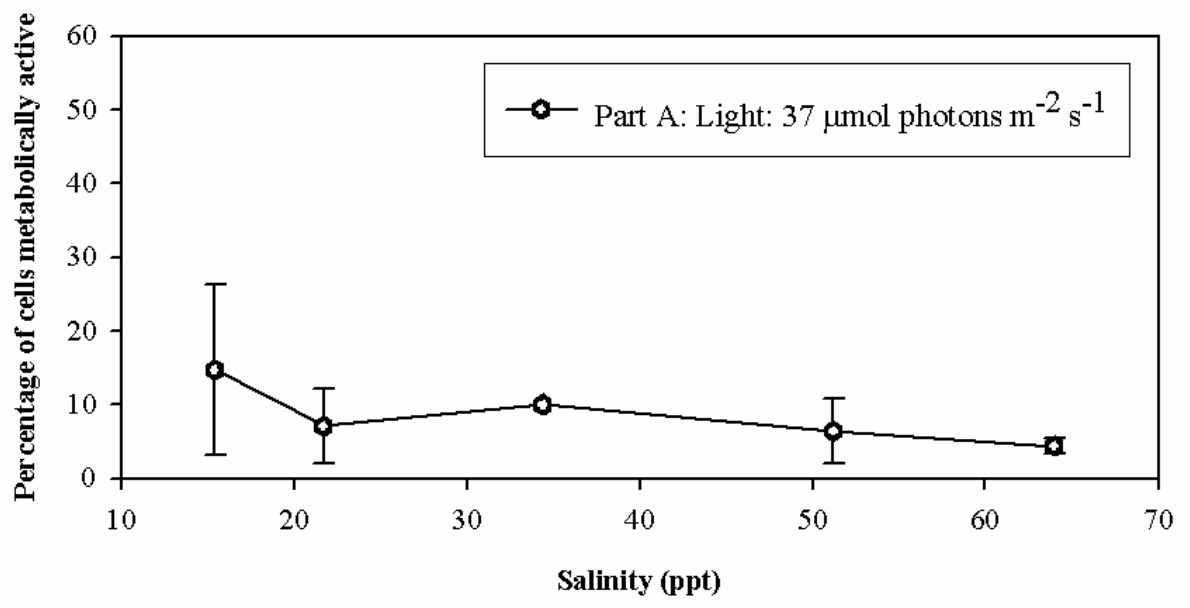

B

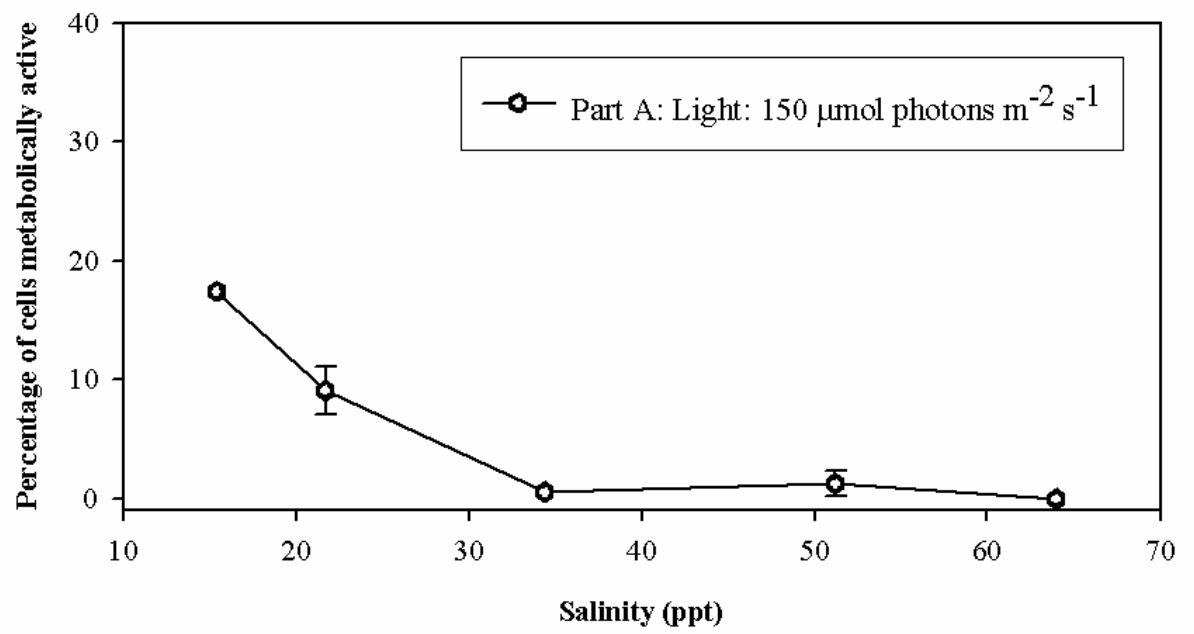

C

Figure 4.4 Influence of light and salinity on metabolic activity of bottom ice bacterial cells for Part A data set. Plotted values are means $\pm 1 \mathrm{SE}$. Absence of error bars indicates missing data value. 


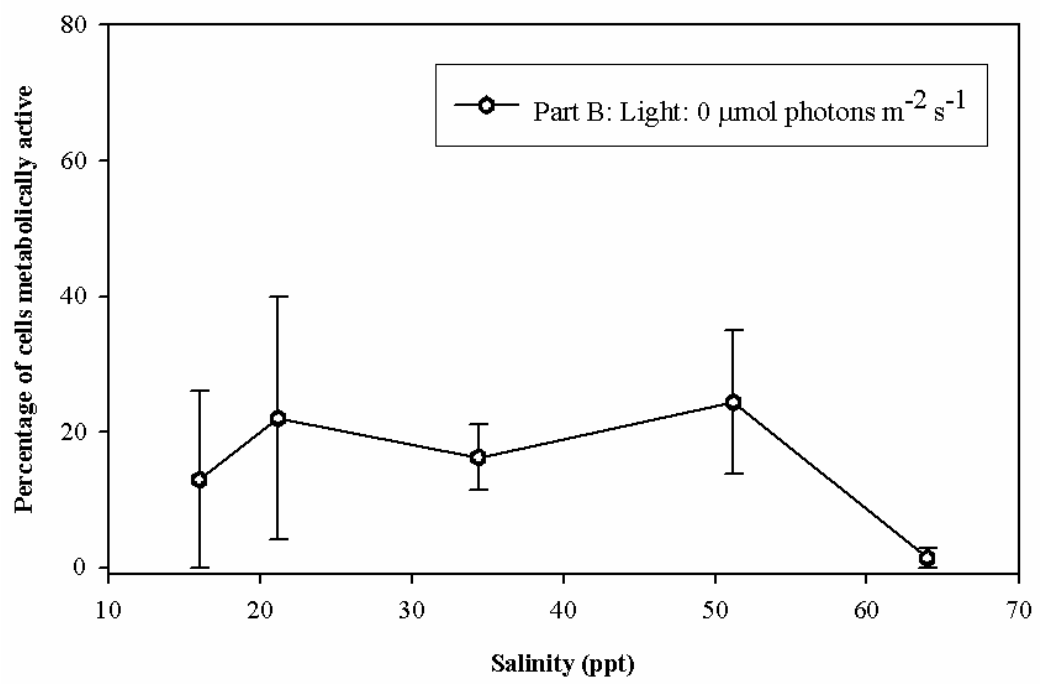

A

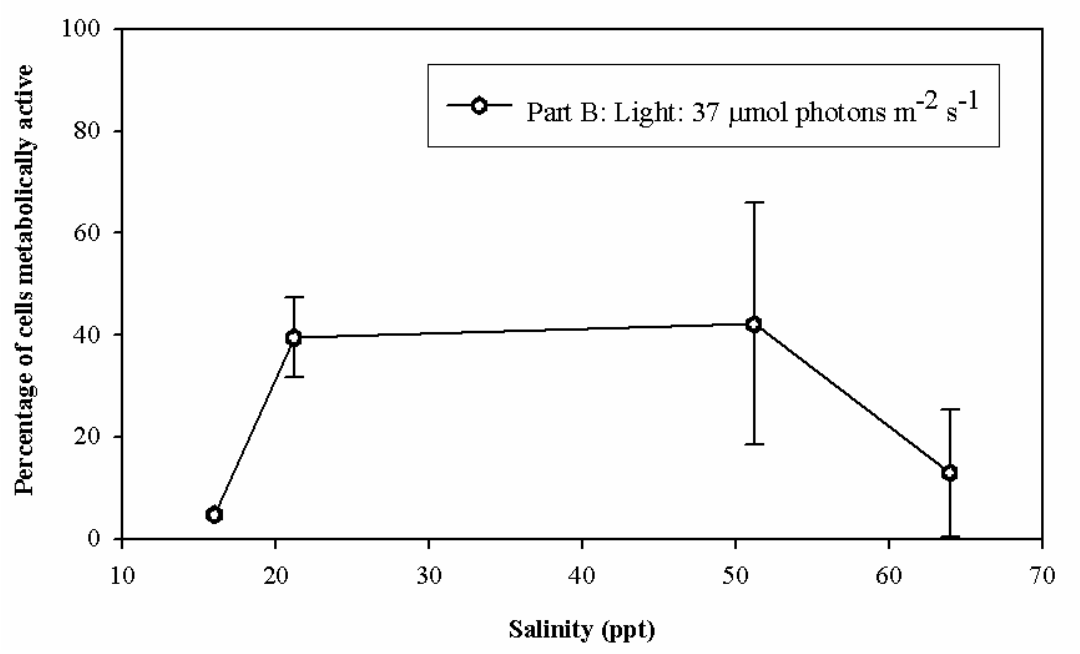

B

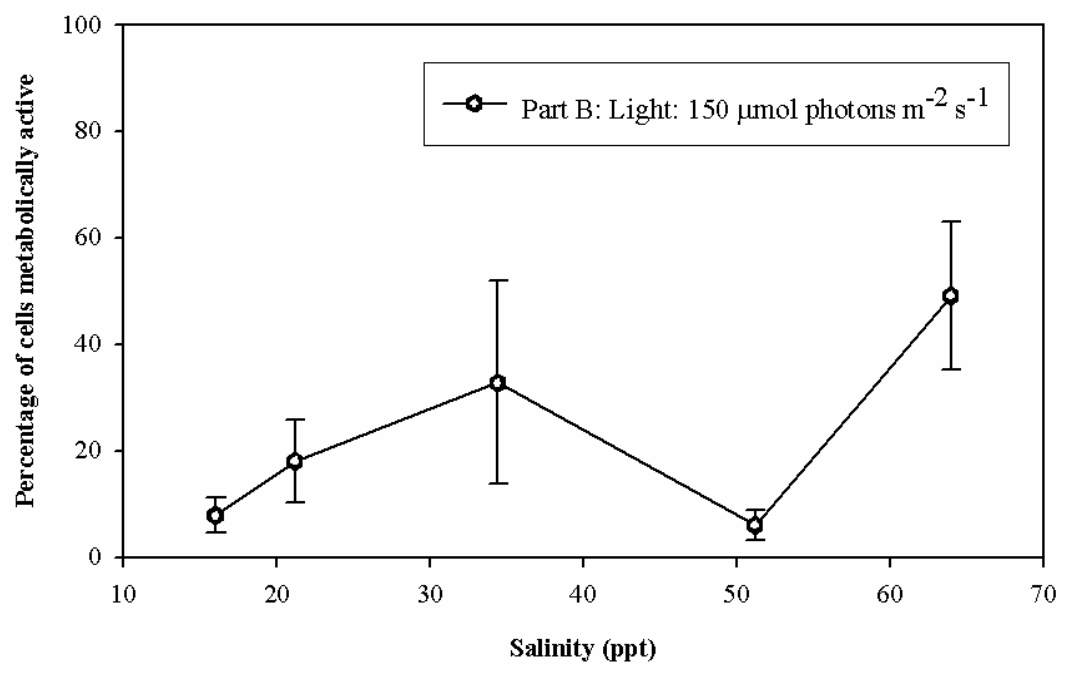

Figure 4.5 Influence of light and salinity on metabolic activity of bottom ice bacterial cells for Part B data set. Plotted values are means $\pm 1 \mathrm{SE}$. 


\subsection{Discussion}

This study represents the first attempt to quantify bacterial metabolic activity in Antarctic sea ice by way of cellular reducing potential. Conducting incubations under a light regime is a novel application of the CTC probe. Limitations in sample size for both experiments and a number of missing data points reflects the logistics involved in conducting experimental work in Antarctica.

Evidence that bacteria actively grow in sea ice dates back as recently as the 1980's. Sullivan and Palmisano (1984) observed large and morphologically distinct cells undergoing cell division, implying an active heterotrophic community.

Microautoradiographic uptake of radiolabeled compounds such as ${ }^{14} \mathrm{C}$-L-serine, ${ }^{3} \mathrm{H}$ serine, ${ }^{3} \mathrm{H}$-glucose and ${ }^{3} \mathrm{H}$-thymidine by bacteria incubated under in situ conditions provided additional evidence of activity in the form of DNA synthesis (Sullivan and Palmisano, 1984; Sullivan et al., 1985). Results presented in this study provide further evidence that bacteria are able to maintain metabolic activity within sea ice, as indicated by cellular reducing potential. Although these experiments have not been conducted in situ, we have demonstrated that the degree of activity reflects abiotic factors associated with a dynamic sea ice environment that includes gradients in light, salinity, temperature and nutrient concentrations (Arrigo and Sullivan, 1992). This discussion will focus on the extent to which bacterial metabolic activity is influenced by light and salinity. 


\subsubsection{Response of the brine community to light}

The bacterial cells present in the brine assemblage of the sea ice profile showed a marked metabolic response to the level of irradiance, particularly at 75 and $150 \mu \mathrm{mol}$ photons $\mathrm{m}^{-2} \mathrm{~s}^{-1}$ (Figure 4.2). These levels of irradiance mirror those expected in situ for the brine community at midday and are thus ecologically relevant. The fact that no cells were deemed metabolically active when incubated in the dark suggests an absolute requirement for light stimulation; even at irradiances less than $37 \mu \mathrm{mol}$ photons $\mathrm{m}^{-2} \mathrm{~s}^{-1}$ metabolic activity appears to be limited. This result most likely reflects the light-driven interaction between algae and bacteria, which has been described by several authors (Grossi et al., 1984; Sullivan and Palmisano, 1984; Kottmeier et al., 1987; Kottmeier and Sullivan, 1990; Stewart and Fritsen, 2004). In particular, Kottmeier et al. (1987) have demonstrated tight coupling between bacterial growth and microalgal photosynthetic metabolism in sea ice in McMurdo Sound, and suggest that microalgae provide bacteria with dissolved organic matter (DOM), either as extracellular polymeric substances and/or dissolved photosynthate. Grossi et al. (1984) propose that in return bacteria provide microalgae with vitamins and/or recycled inorganic nutrients.

The reciprocal interaction between algae and bacteria has more recently been documented in pack ice and pelagic environments by Stewart and Fritsen (2004) and is consistent with observations from similar temperate water experiments (Wetz and Wheeler, 2004). The potential for coupling and uncoupling is also well documented in the literature, which has led to the suggestion that a stable matrix and nutrient source may be more important in determining bacterial distribution (Nichols et al., 1995). 
This may explain why $50 \%$ of the observed abundance and $90 \%$ of the bacterial biomass occurs in the bottom $20 \mathrm{~cm}$ of fast ice (Sullivan and Palmisano, 1984), where the supply of nutrients may become reduced within the ice profile, but is replaced in the interstitial regions by the underlying seawater. However, few studies have quantified the time required for bacteria to respond to algal metabolism. Using the CTC assay, we show that bacteria can switch from relative inactivity to a state of active metabolism within eight hours. Grossmann and Gleitz (1993) examined microbial responses to experimental sea ice formation and determined that the period of time required before algal photosynthesis influenced bacterial production was in excess of two weeks. Our results dramatically shorten this apparent response time and indicate that the microbial community can respond rapidly to environmental change.

Another interpretation of the brine cell response is that limited metabolic activity with respect to low irradiance may imply the presence of photosynthetic or chemosynthetic bacterial species. Metabolically active cells were detected in the bottom community experiment when incubated in the dark, but no active cells were observed in the brine community under similar conditions. An absolute requirement for light may indicate metabolic functioning that does not require exuded algal products. It is not yet known whether light harvesting bacterial species inhabit Antarctic sea ice (Staley et al., 2001), but if such bacterial cells are present in the sea ice they are perhaps more likely to be present closer to the surface of the profile exposed to higher levels of irradiance. Alternatively, initial algal photosynthesis during the eight-hour period of incubation may have triggered a bacterial response, but activity may have ceased due to the diminishing availability of algal supplied DOM. These results indicate that the CTC assay may be useful in determining the presence of autotrophs in future experiments. 


\subsubsection{Response of the bottom community to light and salinity}

Few physiological experiments have been conducted on bacteria occurring in sea ice, despite indications of an important role in community dynamics. Understanding the physiological response of bacteria to the combined stress of temperature, salinity and $\mathrm{pH}$ is important, particularly during initial sea ice formation (Nichols et al., 1999). One of the few studies examining the effect of salinity on bacterial metabolism was that conducted by Kottmeier and Sullivan (1988) from samples of sea ice in McMurdo Sound. These authors determined bacterial incorporation of radiolabelled compounds (thymidine and uridine) and rates of carbon fixation from Hutt Point and Granite Harbour. For both radiolabelled substrates maximum incorporation occurred at salinities from 20ppt to 30ppt with secondary peaks from 50ppt to 70ppt. Much lower rates of incorporation were observed at saline concentrations outside these bounds. In addition, rates of carbon fixation of cells from Granite Harbour peaked at 20ppt to 30ppt and declined markedly above 30ppt. Kottmeier and Sullivan (1988) also examined microalgae and concluded that sea ice heterotrophs exhibit less variation in response to salinity than autotrophs, indicating that bacteria are better adapted for survival and growth in the range of sea ice microhabitats.

Results from the present study are interpreted with caution due to sample size and a possible batch effect of CTC. After the eight-hour period of acclimation similar levels of metabolic activity with respect to salinity were observed, with the exception of the $15.7 \mathrm{ppt}$ treatment (Figure 4.3). This suggests cells were able to acclimate to a range of salinities, but show a higher tolerance for saline concentrations above the $34 \mathrm{ppt}$ salinity of normal surface seawater. 
After the period of incubation, reduced metabolic activity was observed for those cells maintained in the dark, implying a stress response to continued darkness (Figure 4.4:

A; Figure 4.5: A). The influence of salinity on metabolic activity of dark-incubated cells is more difficult to interpret. The part B data show a very slight trend that is comparable with the findings of Kottmeier and Sullivan and (1988); cells are potentially less active at either saline extreme, but are able to tolerate saline concentrations ranging from 20ppt to 50ppt (Figure 4.5:A). The part A data do not support this conclusion. For cells incubated under an irradiance of $37 \mu \mathrm{mol}$ photons $\mathrm{m}^{-}$ ${ }^{2} \mathrm{~s}^{-1}$ the part B data show a similar trend in activity to those cells incubated in the dark with no apparent sensitivity to light exposure (Figure 4.5: B). A very different trend is evident in the part A data with metabolic activity declining rapidly in response to saline concentration (Figure 4.4: B). A similar response to salinity was observed under the maximum light treatment of $150 \mu \mathrm{mol}$ photons $\mathrm{m}^{-2} \mathrm{~s}^{-1}$ (Figure 4.4: C) but there are significantly fewer active cells at this irradiance. The corresponding data from the part B dataset indicate that cells are metabolically inhibited at salinities less than 34ppt. The ambiguity between the two datasets could stem from a number of factors including differences in the composition of algae and bacteria in the two parts of the experiment, variable supply of DOM, or different batches of the CTC stain.

Of the two abiotic factors manipulated however, salinity is more important in influencing the metabolic activity of bacteria occurring in the interstitial region of the sea ice profile. When acclimated over a period of time, cells exhibit a tolerance to changing saline concentrations, but after a further eight hours there is some evidence to suggest activity is reduced at either end of the saline regime. Further study is required to elucidate the mechanistic basis for these current observations, particularly 
in determining whether the in situ bacterial response simply mimics algal metabolism. Ice algae have been shown to exhibit a marked response to salinity with most species showing a severe inhibitory photosynthetic response at salinities greater than 60ppt (Palmisano et al., 1987; Vargo et al., 1986) and likewise at saline concentrations less than 32ppt (Ryan et al., 2004). It is thus difficult in this study to ascertain whether reduced metabolic activity reflects a stress response to saline conditions or a reduced supply of algal exudates. Limited experimental work with isolated sea ice cultures of Antarctic bacteria (Nichols et al., 1999) has demonstrated an upper and lower threshold in generation time with respect to saline concentration, implying that salinity may be one of the primary physicochemical parameters controlling the distribution and abundance of sea ice bacteria (Thomas and Dieckmann, 2002).

Metabolic activity with respect to light produced variable results, however the part B dataset provides some evidence that activity may be independent of light irradiance for bacteria present in the interstitial region of the ice profile. This provides an interesting parallel to the brine community experiment and may indicate that bacteria present at the top of the profile are dependent on light, while the community present in the bottom region may be tolerant of low levels of irradiance. Alternatively, while the diminishing availability of algal supplied DOM may have limited bacterial activity in the brine experiment, there may have been significantly less DOM limitation in the bottom experiment due to the greater biomass in the interstitial region of the ice profile.

Despite the limitation of sample size in this study, the CTC probe appears to be useful in quantifying abiotic effects on cellular activity and is applicable to the logistic 
constraints of Antarctic field conditions. The method is simple, effective and avoids the use of radiolabelled compounds in a pristine environment. Understanding the bacterial response to environmental change in the sea ice ecosystem may provide an insight into the potential long-term changes to the physical oceanography and ecology of the Southern Ocean associated with climate change. The ability of microorganisms to cope with changes in ambient saline concentrations and irradiance levels associated with a reduction in extent and volume of sea ice may determine their capacity to act as 'seed populations' that initiate ice edge blooms. 


\section{Chapter 5: Summary}

While bacteria are now being recognised as a major biological force in the oceanic carbon cycle and ecosystem structure (Azam and Worden, 2004; Häder et al., 1998), our understanding of the diversity and functional capabilities of bacteria present within Antarctic sea ice remains fragmentary. This research provided the opportunity to compare the distribution and abundance of bacteria from two coastal Antarctic regions, and to initiate an understanding of the bacterial response to climate change. The general discussion that follows reviews the main findings of the preceding chapters and provides a broader context for results. The limitations of the study are considered, along with opportunities for future research.

This thesis focused on three main objectives:

1) Development of methods: to develop an understanding of some current techniques in the field of microbial ecology and apply these techniques to Antarctic field conditions (Chapter 2).

2) Distribution and abundance: to compare the distribution and abundance of sea ice bacteria from fast ice and pack ice at two locations in Antarctica and to examine the correlation between bacterial and algal metabolism (Chapter 3).

3) Cell metabolic activity: to determine the metabolic response of bacterial cells to experimental changes in light and salinity (Chapter 4). 


\subsection{Development of methods}

Flow cytometry is a valuable technique for counting natural bacterial assemblages, but is limited by instrument availability and methodology (Sherr et al., 2001). During the course of this work a significant period of time was spent validating methods and comparing various flow cytometers prior to analysing the samples required for subsequent experiments (Chapter 2). The interpretation of flow cytograms (density plots of FL1 Vs. SSC) can require a subjective assessment by the user in distinguishing background instrument noise from bacterial cell populations of interest. In this study, sample storage and fixation were an additional confounding variable in interpreting cytograms. While validating the use of flow cytometry was time consuming, important collaborations were established with researchers from NIWA (New Zealand) and Oregon State University (USA).

In addition, Chapter 2 outlined observations on filtration methods, filter paper membranes, antifade products, and fluorescent stains. This initial work was largely focused at gaining familiarity with epifluorescence microscopy, but also included a short pilot study on marine bacteria in Wellington Harbour. There is some evidence to suggest that bacterial abundance differs with respect to sampling location within the harbour. Further examination was beyond the scope of this study. 


\subsection{Distribution and abundance}

Descriptions of the distribution and abundance of bacteria with respect to fast ice, and in particular pack ice, remain fragmentary (Delille, 1992). Chapter 3 compared the bacterial communities from two coastal locations in Antarctica. Similarities in bacterial abundance and biovolume were observed between fast ice at Cape Hallett and pack ice from the Mertz Glacier region, but the distribution of cells within the ice was found to be significantly different between locations. Additionally, close metabolic coupling between bacteria and algae was observed in annual pack ice but not multiyear fast ice.

Metabolic coupling between bacteria and algae is thought to indicate a functional microbial loop (Stewart and Fritsen, 2004; Pedrós-Alió et al., 2002), however the spatial and temporal nature of this relationship remains unclear. Uncoupling of primary and secondary production may be instigated by the synergistic effects of DOM and temperature limitation (Pomeroy and Wiebe, 2001; Helmke and Weyland, 1995; Stewart and Fritsen, 2004), but it seems that the discrepancy between bacterial and algal biomass observed at Cape Hallett may reflect the presence of multiyear ice. These findings support the general consensus that bacterial biomass generated from algal-derived dissolved organic matter is highly variable across seasons and habitats.

\subsection{Cell metabolic activity}

It is now recognised that an understanding of the ecology of microbial communities requires information about the identity and metabolic activity of individual cells 
(Sherr et al., 2000). This is largely due to the realisation that a significant fraction of bacterial cells visualised by direct microscopic enumeration are either dead or relatively inactive (Choi et al., 1999; Sherr et al., 1999; Sherr et al., 2000). Several techniques are now available, or under development, that provide an insight into the physiological activity of individual microbial cells in marine samples. There is however, no consensus regarding the absolute validity of these methods, or even which are the most reliable (Howard-Jones et al., 2001).

The tetrazolium salt CTC developed by Rodriguez et al. (1992) is an approach to determine cell-specific activity that is becoming increasing recognised. Chapter 4 described the first metabolic assessment of Antarctic sea ice bacteria using this assay. Although the results obtained with CTC are preliminary, due to the novel application of the stain and the limited sample size, this approach warrants further research. The technique is relatively simple and has the major advantage of not requiring the use of radiolabelled compounds in pristine environments such as Antarctica.

The objective here was to determine the metabolic response to light stimulus by bacterial cells present in the brine community. The near linear, positive, trend between cell activity and incubation irradiance was an unexpected and intriguing result. Several explanations may explain the trend, but the most likely is a direct response to the increased availability of algal photosynthate. This study demonstrates for the first time the usefulness of the CTC assay in determining the spatial and temporal coupling of algal and bacterial metabolism. Alternatively, the response may indicate the presence of photosynthetic species. Although photosynthetic bacteria dominate many of the non-marine ecosystems of the Antarctic, such as ponds and lakes (Hawes and 
Schwarz, 2001), they have yet to be described from sea ice. Light-harvesting Cyanobacteria such as Synechococcus spp. and Prochlorococcu spp. are typically absent from coastal and offshore waters in polar regions (Vincent et al., 1999), but at 1.0 and $0.6 \mu \mathrm{m}$ in diameter respectively (Marie et al., 1997), they could be the cells observed in this study. The outcome of this experiment is extremely interesting, and if this explanation were validated, it would be a unique discovery.

A second physiological experiment examined the response of bacterial cells present in the interstitial sea ice region to experimental changes in both light and also salinity which is thought to be the dominant factor in external chemistry influencing microbial assemblages (Thomas and Dieckmann, 2002). Of the two abiotic factors manipulated, salinity may be more important in influencing metabolic activity of bacteria present in bottom ice. When acclimated over a period of eight hours, cells tolerated changing saline concentrations with the exception of the lowest salinity treatment (15.7ppt). After a further eight hours of incubation there is some indication that activity was reduced at either end of the saline regime, irrespective of incubation irradiance. Unfortunately, results were confounded by a batch effect, possibly due to the CTC stain, and need to be treated with caution.

\subsection{Conclusion}

In contrast to studies on Antarctic terrestrial environments, evidence that climate change has influenced the marine biota is limited, and direct impacts on marine microorganisms have been ascertained for very few species (White et al., 2001; Marchant et al., 2001). If current climate trends are sustained, changes in the volume 
and extent of sea ice, ocean circulation, mixing regimes, cloud cover and nutrient input will all influence the gradients in light and salinity that characterise the sea ice environment. Such changes are likely to be complex, wide-ranging and difficult to predict (Marchant et al., 2001).

This work provides the first evidence that bacterial metabolic activity depends on their position within the sea ice profile. Light appears to have a greater influence on bacterial cell activity in the top region of fast ice than on cells present on the bottom. Conversely, bacteria present in the near surface region of the ice profile appear to be adapted to relatively high saline concentrations, while cells in the interstitial region may be less tolerant of saline fluctuations departing from that of ambient seawater (36ppt). Thus, any changes to the volume of annual sea ice and ambient ocean salinity are likely to have an effect on bacterial metabolism as well as community composition.

Reduced ice thickness as a result of climate change would reduce the microbial biomass, thereby limiting the inocula for bloom events at the marginal ice zone and modifying the vertical carbon flux. Exposure to increased solar irradiance may favour some species, especially those with greater UV tolerance (Hernández et al., 2004; Helbing et al., 1995), while warmer, less saline water may pose a physiological stress to others.

While algae have been shown to acclimate to changes in both light and salinity (eg. Ryan et al., 2004) very little is known about possible mechanisms of adaptation in Antarctic bacteria. The extent to which the species distribution reflects abiotic factors 
such as light, salinity and ice profile depth is equally ambiguous. Given the ephemeral nature of the sea ice ecosystem and gradients in abiotic factors, a degree of resilience can be assumed and any long-term climate-related changes may be difficult to predict. However, due to short generation times and their structural simplicity, changes in environmental conditions are often rapidly recognised by unicellular organisms (Jochem, 2000), as has been shown in this study with respect to light and salinity. Community level changes in either the composition of annual sea ice or the underlying water column may cause uncoupling of the microbial loop, which is likely to further reduce both primary and secondary productivity. Alternatively, productivity may be enhanced in the water column and biodiversity may increase if warmer water allows microbes to transit from temperate to polar oceans (Marchant et al., 2001).

It is beyond the scope of this thesis to provide definitive indications as to the effects of sustained increases in global $\mathrm{CO}_{2}$ and temperature on the sea ice microbial community. However the use of physiological probes such as CTC provides useful insight into factors influencing bacterial activity. This will hopefully lead to an understanding of the role of bacteria in structuring healthy and stressed marine or sea ice ecosystems. Understanding the potential stress response of bacterial assemblages to a changing climate has implications not only for sea ice trophodynamics but also Southern Ocean productivity.

\subsection{Limitations of the study}

A significant limitation of this thesis is low sample size, both of survey and in particular experimental work. This reflects the time, weather, and other logistic 
constraints associated with Antarctic fieldwork. It was not possible for sampling sites established in pack ice floes from the Mertz Glacier in 2002 to be periodically resampled as was carried out at Cape Hallett in 2003 as they are continually moved by tides and wind. The sampling regime employed at Cape Hallett was useful in determining short-term increases in bacterial abundance. By comparison, the cores extracted from the Mertz region only provide a 'snapshot' of the pack ice microbial community. It is also recognised that identical sampling methodology be adopted in comparing locations, particularly with respect to an ecosystem that is as spatially and temporally dynamic as Antarctic sea ice, but this was not possible because of the dynamic nature of the pack ice at the Mertz Glacier.

\subsection{Future directions}

An understanding of the potential stress response of bacterial assemblages to environmental change may provide an insight into long-term changes to the sea ice ecosystem. The CTC assay appears to be an effective technique and shows considerable promise for future work in ice-covered regions. Given the lack of consensus with regards validity of results and reliability of the various techniques available, an assessment method that incorporates a range of stains and probes is recommended.

The sea ice bacterial community composition is best assessed using molecular techniques such as PCR amplification of 16S rRNA gene fragments and denaturing gradient gel electrophoresis (DGGE). This approach could contribute significantly to understanding not only the biodiversity of Antarctic bacteria but also the factors which determine species distribution and the structure of healthy and stressed marine 
ecosystems. Correlating the taxonomic composition with the spatial, and possibly even temporal, dynamics of sea ice would enable species-specific responses to climate change to be quantified. It may also provide a clearer indication of the importance of bacterial bloom events at the marginal ice zone.

Photosystem inhibitors such as 2,4,6 trinitrophenyl or dichlorophenyl dimethyl urea (DCMU) could be used to separate the photosynthetic response of algae and bacterial metabolic activity. This would allow an assessment of whether metabolic activity reflects a direct or indirect response to abiotic factors. A combination of molecular identification techniques such as PCR in conjunction with photosystem inhibitors would be a useful approach in validating the presence of photosynthetic bacterial species.

The majority of research efforts, including the present work, have relied on bulk analyses of melted ice samples or extracted brine (Jung et al., 2001). The extent to which investigations of this type reflect the in situ distribution of microbes with respect to the brine inclusions and interstices of the ice matrix is not known. It is also assumed that the experimental assessment of metabolic activity serves as a valid proxy for in situ processes, but brine extraction and melting of ice cores prior to incubation may significantly influence the physiological state of bacterial cells. This issue was not addressed in this study but could be quantified using in situ methods.

A technique recently developed by Jung et al. (2001) has enabled in situ DAPI staining of bacteria localised within the three dimensional framework of brine inclusions. This approach allows microbial populations to be examined at a spatial 
scale relevant to the microbial community. Adapting this technique to provide an in situ assessment of metabolic activity, possibly in conjunction with species- specific oligonucleotide probes, is an exciting prospect for future work.

Understanding the spatial and temporal dynamics of Antarctic sea ice and the associated biotic communities is fundamental to quantifying Southern Ocean productivity and the trophodynamics of the Antarctic coastal ecosystem. This research has shown that cell-specific techniques with image analysis and flow cytometry can provide a valuable insight into the structure of bacterial assemblages. By integrating the techniques emerging in the field of microbial ecology, it may now be possible to elucidate the role of bacteria in Antarctic sea ice. As a result, a mechanistic understanding of productivity and trophodynamics in the Antarctic coastal ecosystem, and prognostic models for qualifying the resilience of the microbial community to climate change, may soon be realised. 


\section{References}

Ackley, S.F.; Sullivan, C.W. 1994. Physical controls on the development and characteristics of Antarctic sea ice biological communities - a review and synthesis. Deep-Sea Research 41(10): 1583-1604.

Archer, S.D.; Leakey, R.J.G.; Burkill, P.H.; Sleigh, M.A.; Appleby, C.J. 1996.

Microbial ecology of sea ice at a coastal Antarctic site: community composition, biomass and temporal change. Marine Ecology Progress Series 135: 179-195.

Arrigo, K.R.; Lizotte, M.P.; Dixon, P.; Dieckmann, G. 1997. Primary prodution in Antarctic sea ice. Science 276: 394-397.

Arrigo, K.R.; Robinson, D.H.; Worthen, D.L.; Dunbar, R.B.; DiTullio, G.R.; Van Woert, M.; Lizotte, M.P. 1999. Phytoplankton Community Structure and the Drawdown of Nutrients and CO2 in the Southern Ocean. Science 283(5400): 365-367.

Arrigo, K.R.; Sullivan, C.W. 1992. The influence of salinity and temperature covariation on the photophysiological characteristics of Antarctic sea ice microalgae. Journal of Phycology 28: 746-756.

Arrigo, K.R.; van Dijken, G.L. 2003. Phytoplankton dynamics within 37 Antarctic coastal polynya systems. Journal of Geophysical Research 108(C8): 3271.

Arrigo, K.R.; Worthen, D.; Schnell, A.; Lizotte 1998. Primary production in Southern Ocean waters. Journal of Geophysical Research 103(C8): 15587-15600.

Azam, F.; Smith, D.C.; Hollibaugh, J.T. 1991. The role of the microbial loop in Antarctic pelagic ecosystems. Polar Research 10(1): 239-243.

Azam, F.; Worden, A.Z. 2004. Microbes, Molecules, and Marine Ecosystems. Science 303: $1622-1624$. 
Becton Dickinson. Flow Cytometry Manual. BD Biosciences, California, United States. Unpublished.

Bigg, G.R.; Jickells, T.D.; Liss, P.S.; Osborn, T.J. 2003. The role of the oceans in climate. International Journal of Climatology 23: 1127-1159.

Borsheim, K.Y. 1990. Bacterial biomass and production rates in the Gulf Stream front regions. Deep-Sea Research 37(8): 1297-1309.

Brown, M.V. 2000. A molecular phylogenetic survey of polar sea ice microbial communities. PhD thesis, University of Tasmania, Hobart, Australia.

Budd, W.F. 1991. Antarctica and Global Change. Climate Change 18: 271-299.

Bunthof, C.J.; Abee, T. 2002. Development of a Flow Cytometric Method To Analyze Subpopulations of Bacteria in Probiotic Products and Dairy Starters. Applied and Environmental Microbiology 68(6): 2934-2942.

Campbell, L. 2001. Flow Cytometric Analysis of Autotrophic Picoplankton. Methods in Microbiology 30: 317-341.

Choi, J.W.; Sherr, B.F.; Sherr, E.B. 1999. Dead or alive? A large fraction of ETSinactive marine bacterioplankton cells, as assessed by reduction of CTC, can become ETS-active with incubation and substrate addition. Aquatic Microbial Ecology 18: 105-115.

Cole, J.J. 1999. Aquatic Microbiology for Ecosystem Scientists: New and Recycled Paradigms in Ecological Microbiology. Ecosystems 2: 215-225.

Constable, A.J.; Nicol, S. 2003. Southern Ocean productivity in relation to spatial and temporal variation in the physical environment. Journal of Geophysical Research 108(C4): 6-1 - 6-21. 
Cota, G.F.; Kottmeier, S.T.; Robinson, D.H.; Smith, W.O.; Sullivan, C.W. 1990. Bacterioplankton in the marginal ice zone of the Weddell Sea: biomass, production and metabolic activities during austral autumn. Deep-Sea Research 37(7): 1145-1167.

Crain, J. 2003. Manual for running samples on the Becton-Dickinson 4-Colour flow cytometer in COAS. Sherr lab FCM facility. Unpublished.

Creach, V.; Baudoux, A-C.; Bertru, G.; Le Rouzic, B. 2003. Direct estimate of active bacteria: CTC use and limitations. Journal of Microbiological Methods 52: 19-28.

Daly, K.L. 1990. Overwintering development, growth, and feeding of larval Euphausia superba in the Antarctic marginal ice zone. Limnology and Oceanography 35(7): 1564-1576.

del Giorgio, P.A.; Bouvier, T.C. 2002. Linking the physiologic and phyolgenetic successions in free-living bacterial communities along an estuarine salinity gradient. Limnology and Oceanography 37(2): 471-486.

del Giorgio, P.A.; Prairie, Y.T.; Bird, D.F. 1997. Coupling Between Rates of Bacterial Production and the Abundance of Metabolically Active Bacteria in Lakes, Enumerated Using CTC Reduction and Flow Cytometry. Microbial Ecology 34: 144154.

Delille, D.; Fiala, M.; Rosiers, C. 1992. Marine bacterioplankton at the Weddell Sea ice edge, distribution of psychrophilic and psychrotrophic populations. Polar Biology 12: $205-210$.

Delille, D.; Fiala, M.; Rosiers, C. 1995. Seasonal changes in phytoplankton and bacterioplankton distribution at the ice-water interface in the Antarctic neritic area. Marine Ecology Progress Series 123: 225-233.

Ducklow, H.; Carlson, C.; Smith, W. 1999. Bacterial growth in experimental plankton assemblages and seawater cultures from the Phaeocystis antarctica bloom in the Ross Sea, Antarctica. Aquatic Microbial Ecology 19: 215-227. 
Ducklow, H.; Carlson, C.; Church, M.; Kirchman, D.; Smith, D.; Steward, G. 2001. The seasonal development of the bacteriplankton bloom in the Ross Sea, Antarctica, 1994-1997. Deep-Sea Research II 48: 4199-4221.

Fritsen, C.H.; Coale, S.L.; Neenan, D.R.; Gibson, A.H.; Garrison, D.L. 2001. Biomass, production and microhabitat characteristics near the freeboard of ice floes in the Ross Sea, Antarctica, during the austral summer. Annals of Glaciology 33:: 288296.

Fry, J.C.; Davies, A.R. 1985. An assessment of methods for measuring volumes of planktonic bacteria, with particular reference to television image analysis. Journal of Applied Bacteriology 58: 105-112.

Garrison, D.L. 1991. Antarctic Sea Ice Biota. American Zoologist 31: 17-33.

Garrison, D.L.; Buck, K.R. 1991. Surface-layer sea ice assemblages in Antarctic pack ice during the austral spring: environmental conditions, primary productivity and community structure. Marine Ecology Progress Series 75: 161-172.

Garrison, D.L.; Sullivan, C.W.; Ackley, S.F. 1986. Sea Ice Microbial Communities in Antarctica. BioScience 36(4): 243-250.

Gasol, J.M.; del Giorgio, P.A. 2000. Using flow cytometry for counting natural planktonic bacteria and understanding the structure of planktonic bacterial communities. Scientia Marina 64(2): 197-224.

Gasol, J.M.; Zweifel, U.L.; Peters, F.; Fuhrman, J.A.; Hagstrom, A. 1999. Significance of Size and Nucleic Acid Content Heterogeneity as Measured by Flow Cytometry in Natural Planktonic Bacteria. Applied and Environmental Microbiology 65(10): 4475-4483.

Gasol, J.M.; del Giorgio, P.A.; Massana, R.; Duarte, C.M. 1995. Active versus inactive bacteria: a size-dependence in a coastal marine plankton community. Marine Ecology Progress Series 128: 91-97. 
Giesenhagen, H.C.; Detmer, A.E.; de Wall, J.; Weber, A.; Gradinger, R.R.; Jochem, F.J. 1999. How are Antarctic planktonic microbial food webs and algal blooms affected by melting of sea ice? Microcosm simulations. Aquatic Microbial Ecology 20: 183-201.

Givan, A.L. 2001. Flow Cytometry First Principles. John Wiley \& Sons 274p.

Gleitz, M.; Grossmann, S.; Scharek, R.; Smetacek, V. 1996. Ecology of diatom and bacterial assemblages in water associated with melting summer sea ice in the Weddell Sea, Antarctica. Antarctic Science 8(2): 135-146.

Gordon, H.B.; O'Farrell, S.P. 1997. Transient climate change in the CSIRO coupled model with dynamic sea ice. Monthly Weather Review 25: 875-907.

Gordon, S. 2003. LGP Initial Environmental Evaluation. Antarctica New Zealand: $35 \mathrm{p}$.

Grossi, S.M.; Kottmeier, S.T.; Sullivan, C.W. 1984. Sea Ice Microbial Communities

III. Seasonal abundance of microalgae associated bacteria in McMurdo Sound, Antarctica. Microbial Ecology 10: 231-242.

Grossmann, S.; Gleitz, M. 1993. Microbial responses to experimental sea-ice formation: implications for the establishment of Antarctic sea-ice communities. Journal of Experimental Marine Biology and Ecology 173: 273-289.

Häder, D-P. 1997. Effects of UV Radiation on Phytoplankton. Advances in Microbial Ecology 15: 1-26.

Häder, D-P.; Kumar, H.D.; Smith, R.C.; Worrest, R.C. 1998. Effects on aquatic ecosystems. Journal of Photochemistry and Photobiology B: Biology 46: 53-68.

Harrington, H.J.; Wood, B.L.; McKellar, I.C.; Lensen, G.J. 1967. Topography and Geology of the Cape Hallett District, Victoria Land, Antarctica, New Zealand Department of Scientific and Industrial Research: 99p. 
Hawes, I; Schwarz, AMJ 2001. Absorption and utilisation of irradiance by cyanobacterial mats in two ice-covered Antarctic lakes with contrasting light climates. Journal of Phycology 37(1): 5-15.

Helbling, E.W.; Marguet, E.R.; Villafane, V.E.; Holm-Hansen, O. 1995.

Bacterioplankton viability in Antarctic waters as affected by solar ultraviolet radiation. Marine Ecology Progress Series 126: 293-298.

Helmke, E.; Weyland, H. 1991. Bacteria in sea ice and underlying water of the eastern Weddell Sea in midwinter. Marine Ecology Progress Series 117: 141-163.

Hernández, E.A.; Ferreyra, G.A.; Mac Cormack, W.P. 2004. Effect of solar radiation and the subsequent dark periods on two newly isolated and characterised Antarctic marine bacteria. Polar Research 23(1): 67-77.

Hiebert, R.D.; Sweet, R.G. 1985. Electronics for Flow Cytometers and Sorters. In: Flow Cytometry: Instrumentation and Data Analysis. Van Dilla, M. A. Dean., P.N.; Laerum, O.D.; Melamed, M.R. (Eds). Academic Press Harcourt Brace Jovanovich, Publishers: $288 \mathrm{p}$.

Howard-Jones, M.H.; Frischer, M.E.; Verity, P.G. 2001. Determining the Physiological Status of Individual Bacterial Cells. Methods in Microbiology 30: 175206.

Howard-Williams, C.; Peterson, D. 2000. The Latitudinal Gradient Project: "A Discussion Paper". Antarctic New Zealand.

Jochem, F.J. 2000. Probing the physiological state of phytoplankton at the single-cell level. Scientia Marina 64(2): 183-195.

Joos, F.; Ramirez-Rojas, A.; Stone, J.M.R.; Zillman, J. 2001. Climate Change 2001: Technical Summary of the Working Group I Report of the Intergovernmental Panel on Climate Change. Switzerland, IPCC. 
Junge, K.; Krembs, C.; Deming, J.; Stierle, A.; Eicken, H. 2001. A microscopic approach to investigate bacteria under in situ conditions in sea-ice samples. Annals of Glaciology 33: 304-310.

Knox, G.A. 1994. The Biology of the Southern Ocean. Cambridge University Press $444 p$.

Kottmeier, S.T.; McGrath Grossi, S.; Sullivan, C.W. 1987. Sea ice microbial communities. VIII. Bacterial production in annual sea ice of McMurdo Sound, Antarctica. Marine Ecology Progress Series 35: 175-186.

Kottmeier, S.T.; Sullivan, C.W. 1987. Late winter primary production and bacterial production in sea ice and seawater west of the Antarctic Peninsula. Marine Ecology Progress Series 36: 287-298.

Kottmeier, S.T.; Sullivan, C.W. 1988. Sea Ice Microbial Communities IX. Effects of temperature and salinity on metabolism and growth of autotrophs and heterotrophs. Polar Biology 8: 293-304.

Kottmeier, S.T.; Sullivan, C.W. 1990. Bacterial biomass and production in pack ice of Antarctic marginal ice edge zones. Deep-Sea Research 37(8): 1311-1330.

Kühl, M.; Glud, R.N.; Borum, J.; Roberts, R.; Rysgaard, S. 2001. Photosynthetic performance of surface-associated algae below sea ice as measured with a pulseamplitude-modulated (PAM) fluorometer and $\mathrm{O}_{2}$ microsensors. Marine Ecology Progress Series 223: 1-14

Legendre, L.; Ackley, S.F.; Dieckmann, G.S.; Gulliksen, B.; Horner, R.; Hoshiai, T.; Melnikov, I.A.; Reeburgh, W.S.; Spindler, M.; Sullivan, C.W. 1992. Ecology of sea ice biota. 2. Global Significance. Polar Biology 12: 429-444. 
Lepesteur, J.M.; Fleury, M.A. 1993. A comparative study of different preservation methods for phytoplankton cell analysis by flow cytometry. Marine Ecology Progress Series 93: 55-63.

Li, W.K.W.; Head, E.J.H.; Harrison, W.G. 2004. Macroecological limits of heterotrophic bacterial abundance in the ocean. Deep-Sea Research 51: 1529-1540.

Li, Y.; Dick, W.A.; Tuovinen, O.H. 2004a. Fluorescence microscopy for visualisation of soil microorganisms - a review. Biology of Fertile Soils 39: 301-311.

Manning, M.; Nobre, C.(Eds). 2001. Climate Change 2001: Impacts adaptations and vulnerability. Technical Summary Report of Working Group II of the Intergovernmental Panel on Climate Change. Switzerland, IPCC.

Marchant, H.J.; Davidson, A.T.; Wright, S.W. 2001. Antarctic Marine Microorganisms and Climate Change: Impacts and Feedbacks. Ocean and Polar Research 23(4): 401-410.

Marie, D.; Partensky, F.; Jacquet, S.; Vaulot, D. 1997. Enumeration and Cell Cycle Analysis of Natural Populations of Marine Picoplankton by Flow Cytometry Using the Nucleic Acid Stain SYBR Green 1. Applied and Environmental Microbiology 63(1): 186-193.

Massom, R.A.; Jacka, K.; Pook, M.J.; Fowler, C.; Adams, N.; Bindoff, N. 2003. An anomalous late-season change in the regional sea ice regime in the vacinity of the Mertz Glacier Polynya, East Antarctica. Journal of Geophysical Research 108(C7): 3212.

McMinn, A.; Ashworth, C.; Ryan, K.G. 2000. In situ net primary productivity of an Antarctic fast ice bottom algal community. Aquatic Microbial Ecology 21: 177-185.

Meiners, K.;Brinkmeyer, R.; Granskog, M.A.; Lindfors, A. 2004. Abundance, size distribution and bacterial colonisation of exopolymer particles in Antarctic sea ice (Bellingshausen Sea). Aquatic Microbial Ecology 35: 283-296. 
Miller, M.A.; Krempin, D.W.; Manahan, D.T.; Sullivan, C.W. 1984. Growth rates, distribution, and abundance of bactria in the ice-edge zone of the Weddell and Scotia Seas, Antarctica. Antarctic Journal of the United States XIX - No. 5: 103-105.

Monfort, P.; Baleux, B. 1992. Comparison of Flow Cytometry and Epifluorescence Microscopy for Counting Bacteria in Aquatic Ecosystems. Cytometry 13: 188-192.

Nichols, D.S.; Greenhill, A.R.; Shadbolt, C.T.; Ross, T.; McMeekin, T.A. 1999. Physiochemical Parameters for Growth of the Sea Ice Bacteria Glaciecola punicea ACAM $611^{\mathrm{T}}$ and Geldicacter sp. Strain IC158. Applied and Environmental Microbiology 65(8): 3757-3760.

Nichols, D.S.; Nichols, P.D.; McMeekin, T.A. 1995. Ecology and physiology of psychrophilic bacteria from Antarctic saline lakes and sea ice. Scientific Progress 78: 311-347.

Nybakken, J.W. 1997. Marine Biology An Ecological Approach. Addison-Wesley Educational Publishers Inc. 481p.

Palmisano, A.C.; Garrison, D.L. 1993. Mircoorganisms in Antarctic Sea Ice. In: Antarctic Microbiology. Friedmann, E. I. (Ed). Wiley-Lizz, Inc.: 167-218.

Palmisano, A.C.; Sullivan, C.W. 1983. Sea ice microbial communities. (SIMCO) I. Distribution, abundance, and primary production of ice microalgae in McMurdo Sound, Antarctica in 1980. Polar Biology 2: 171-177.

Palmisano, A.C.; SooHoo, J.B.; Sullivan, C.W. 1987. Effects of four environmental variables on photosynthesis-irradiance relationships in Antarctic sea ice microalgae. Marine Biology 94: 299-306.

Pedrós-Alió, C.; Vaqué, D.; Guixa-Boisereu, N.; Gasol, J.M. 2002. Prokaryotic plankton biomass and heterotrophic production in western Antarctic waters during the 1995-1996 austral summer. Deep-Sea Research II 49: 805-825. 
Pinkel, D.; Stovel, R. 1985. Flow Chambers and Sample Handling. In: Flow Cytometry: Instrumentation and Data Analysis. Van Dilla, M. A. Dean, P.N.; Laerum, O.D.; Melamed, M.R. (Eds). Academic Press Harcourt Brace Jovanovich, Publishers: 288 p.

Ploem, J.S. 1989. Fluorescence Microscopy. In: Light microscopy in biology a practical approach. Lacey, A. J. (Ed). IRL Press: 329p.

Pomeroy, L.R.; Wiebe, W.J. 2001. Temperature and substrates as interactive limiting factors for marine heterotrophic bacteria. Aquatic Microbial Ecology 23: 187-204.

Porter, J.; Diaper, J.; Edwards, C.; Pickup, R. 1995. Direct Measurements of Natural Planktonic Bacterial Community Viability by Flow Cytometry. Applied and Environmental Microbiology 61(7): 2783-2786.

Priscu, J.C.; Palmisano, A.C.; Priscu, L.R.; Sullivan, C.W. 1989. Temperature dependence of inorganic nitrogen uptake and assimilation in Antarctic sea ice microalgae. Polar Biology 9: 443-446.

Ralph, P.; Ryan, K.; Martin, A.; Fenton, G. Fast kinetics fluorometry on Antarctic bottom ice and brine algae. in prep.

Reid, K.; Croxall, J.P. 2001. Environmental response of upper trophic-level predators reveals a system change in an Antarctic marine ecosystem. Proceedings of the Royal Society of London. Series B: 268: 377-384.

Robertson, B.R.; Button, D.K. 1989. Characterising aquatic bacteia according to population, cell size, and apparent DNA content by flow cytometry. Cytometry 10: 70-76.

Robertson, B.R.; Button, D.K.; Koch, A.L. 1998. Determination of the Biomass of Small Bacteria at Low Concentrations in a Mixture of Species with Forward Light 
Scatter Measurements by Flow Cytometry. Applied and Environmental Microbiology 64(10): 3900-3909.

Rodriguez, G.G.; Phipps, D.; Ishiguro, K.; Ridgway, H.F. 1992. Use of a Fluorescent Redox Probe for Direct Visualization of Actively Respiring Bacteria. Applied and Environmental Microbiology 58(6): 1801-1808.

Ryan, K.; Ralph, P.; Martin, A.; Fenton, G. The effect of salinity and light on the productivity of bottom ice algae examined by PAM and PEA fluorometry. In prep.

Ryan, K.G.; Beaglehole, D. 1994. Ultraviolet radiation and bottom-ice algae:

Laboratory and field studies from McMurdo Sound, Antarctica. Ultraviolet Radiation in Antarctica: Measurements and Biological Effects Antarctic Research Series 62: 229-242.

Ryan, K.G.; McMinn, A.; Mitchell, K.A.; Trennery, L. 2002. Mycosporine like amino acids in Antarctic sea ice algae, and their response to UVB radiation. Zeitschrifft fur Naturforshhung 57 C: 461-477.

Ryan, K.G.; Ralph, P.; McMinn, A. 2003. Pulse Amplitude Modulation (PAM) Fluorescence of the acclimation of Bottom Ice Algal communities during melting to different salinities. In prep.

Ryan, K.G.; Ralph, P.; McMinn, A. 2004. Photoacclimation of Antarctic bottom ice algal communities to lowered salinities during melting. Polar Biology 27(11): 679686.

Sarmiento, J.L.; Le Quere. 1996. Oceanic Carbon Dioxide Uptake in a Model of Century-Scale Global Warming. Science 274: 1346-1350.

Shapiro, H.M. 1988. Practical Flow Cytometry Second Edition. Alan R. Liss, Inc. New York 353p. 
Sherr, B.F.; del Giorgio, P.; Sherr, E.B. 1999a. Estimating abundance and single-cell characteristics of respiring bacteria via the redox dye CTC. Aquatic Microbial Ecology 18: 117-131.

Sherr, B.F.; Sherr, E.; del Giorgio, P. 2001. Enumeration of Total and Highly Active Bacteria. Methods in Microbiology 30: 129-159.

Sherr, E.B.; Sherr, B.F.; Sigmon, C.T. 1999. Activity of marine bacteria under incubated and in situ conditions. Aquatic Microbial Ecology 20: 213-223.

Sieracki, M.E.; Cucci, R.L.; Nicinski, J. 1999. Flow Cytometric Analysis of 5 - Cyano - 2,3 - Ditolyl Tetrazolium Chloride Activity of Marine Bacterioplankton in Dilution Cultures. Applied and Environmental Microbiology 65(6): 2409-2417.

Simon, M.; Azam, F. 1989. Protein content and proteinsynthesis rates of planktonic marine bacteria. Marine Ecology Progress Series 51: 201-213.

Smith, E.M.; del Giorgio, P.A. 2003. Low fractions of active bacteria in natural aquatic communities? Aquatic Microbial Ecology 31: 203-208.

Smith, I.N.; Budd, W.F.; Reid, P. 1998. Model estimates of Antarctic accumulation rates and relationship to temperature changes. Annals of Glaciology 27: 246-250.

Staley, J.T.; Gosink, J.J. 1999. Poles Apart: Biodiversity and Biogeography of Sea Ice Bacteria. Annual Review of Microbiology 53: 189-215.

Staley, J.T.; Junge, K.; Deming, J. 2002. And some like it cold: Sea ice microbiology. In: Biodiversity of Microbial Life. Staley, J. T. Reysenbach, A-L. (Eds). Wiley-Liss Inc. New York: 552p.

Stewart, F.J.; Fritsen, C.H. 2004. Bacteria-algae relationships in Antarctic sea ice. Antarctic Science 16(2): 143-156. 
Sullivan, C.W. 1985. Sea ice bacteria: Reciprocal interactions of the organisms and their environment. In: Ice Biota. Horner, R.(Ed). Chemical Rubber Company, Boca Raton, FLA: 160-171.

Sullivan, C.W.; Cota, G.F.; Krempin, D.W.; Smith, W.O.Jr. 1990. Distribution and activity of bacterplankton in the marginal ice zone of the Weddell-Scotia Sea during austral spring. Marine Ecology Progress Series 63: 23-252.

Sullivan, C.W.; Palmisano, A.C. 1981. Sea-ice microbial communities in McMurdo Sound. Antarctic Journal Review of the United States. 16: 126-127.

Sullivan, C.W.; Palmisano, A.C. 1984. Sea ice microbial communities: Distribution, abundance, and diversity of ice bacteria in McMurdo Sound, Antarctica, in 1980. Applied and Environmental Microbiology 47: 788-795.

Sullivan, C.W.; Palmisano, A.C.; SooHoo, J.B. 1984. Influence of sea ice and sea ice biota on downwelling irradiance and spectral composition of light in McMurdo Sound. Ocean Optics VII. Proc. Internatl. Soc. of Optical Engineers. Blizard, M. A. 489: 159-165.

Sullivan, C.W.; Palmisano, A.C.; Kottmeier, S.; Grossi, S.M.; Moe, R. 1985. The influence of light on growth and development of the sea ice microbial community in McMurdo Sound. Fourth SCAR Symposium on Antarctic Biology, Nutrient Cycles and Food Webs. Siegfried, R.; Condy, P.R.; Laws, R.M. (Eds). Springer-Verlag, Berlin, p78-83.

Taylor, D.L.; Salmon, E.D. 1989. Basic Fluorescence Microscopy. Fluorescence Microscopy of Living Cells in Culture Part A. In: Wang, Y.; Taylor., D.L.(Eds). Academic Press, INC. Harcourt Brace Jovanovich, Publishers: 333p.

Thomas, D.N.; Dieckmann, G.S. 2002. Antarctic Sea Ice - a Habitat for Extremophiles. Science 295: 641-644. 
Thomas, D.N.; Kattner, G.; Engbrodt, R.; Giannelli, V.; Kennedy, H.; Haas, C.; Dieckmann, G.S. 2001. Dissolved organic matter in Antarctic sea ice. Annals of Glaciology 33: 297-302.

Trenerry, L.J.; McMinn, A.; Ryan, K.G. 2002. In situ oxygen microelectrode measurements of bottom-ice algal production in McMurdo Sound, Antarctca. Polar Biology 25: 72-80.

Troussellier, M.; Courties, C.; Vaquer, A. 1993. Recent applications of flow cytometry in aquatic microbial ecology. Biology of the Cell 78(1-2): 110-121.

Troussellier, M.; Courties, C.; Zettelmaier, S. 1995. Flow Cytometric Analysis of Coastal Lagoon Bacterioplankton and Picophytoplankton: Fixation and Storage Effects. Estuarine, Coastal and Shelf Science 40: 621-633.

Turley, C.M.; Hughes, D.J. 1992. Effects of storage on direct estimates of bacterial numbers of preserved seawater samples. Deep-Sea Research 39(3/4): 375-394.

Turley, C.M.; Hughes, D.J. 1994. The effect of storage temperature on the enumeration of epiflurorescence-detectable bacterial cells in preserved sea-water samples. Journal of the Marine Biological Association of the U.K. 74: 259-262.

Ullrich, S.; Karrasch, B.; Hoppe, H-G.; Jeskulke, K.; Mehrens, M. 1996. Toxic Effects on Bacterial Metabolism of the Redox Dye 5-Cyano-2,3-Ditolyl Tetrazolium Chloride. Applied and Environmental Microbiology 62(12): 4587-4593.

Vaqué, D.; Calderon-Paz, J.I.; Guixa-Boixereu, N.; Pedros-Alio, C. 2002. Spatial distribution of microbial biomass and activity (bacterivory and bacterial production) in the northern Weddell Sea during the austral summer (January 1994). Aquatic Microbial Ecology 29: 107-121.

Vargo, G.A.; Fanning, K.; Heil, C.; Bell, L. 1986. Growth rates and the salinity response of an Antarctic ice microfloral community. Polar Biology 5: 241-247. 
Vincent, W.F. 1988. Microbial ecosystems of Antarctica. Cambridge University Press $304 p$.

Vincent, W.F.; Bowman, J.P.; Rankin, L.M.; McMeekin, T.A. 1999. Proceedings of the $8^{\text {th }}$ International Symposium on Microbial Ecology. Bell, C.R.; Brylinsky, M.; Johnson-Green, P. (Eds). Atlantic Canada Society for Microbial Ecology, Halifax, Canada.

Waterhouse, E. 2001. Ross Sea Region 2001: A state of the environment report for the Ross Sea Region of Antarctica. Antarctica New Zealand

Wendler, G.; Worby, A.P. 2001. The surface energy budget in the Antarctic summer sea-ice pack. Annals of Glaciology 33: 275-279.

Wetz, M.S.; Wheeler, P.A. 2004. Response of bacteria to simulated upwelling phytoplankton blooms. Marine Ecology Progress Series 272: 49-57.

Wheeless, L.L.Jr.; Kay, D.B. 1985. Optics, Light Sources, Filters, and Optical Systems. In: Flow Cytometry: Instrumentation and Data Analysis. Van Dilla, M. A. Dean., P.N.; Laerum, O.D.; Melamed, M.R., Academic Press Harcourt Brace Jovanovich, Publishers: 288p.

Wolff, E.W. 2003. Whither Antarctic Sea Ice? Science 302(5648): 1164.

Wu, X.; Simmonds, I.; Budd, W.F. 1997. Modelling of Antarctic Sea Ice in a General Circulation Model. American Meteorological Society 10: 593-609. 